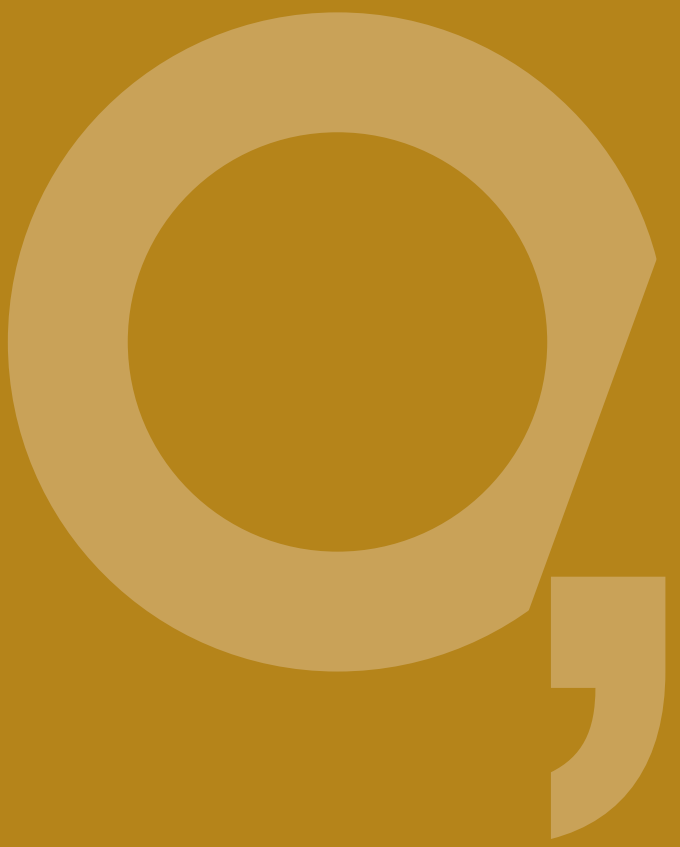

PROCOMMA ACADEMIC 2017

\title{
Mitattava viestintä
}





Mitattava viestintä

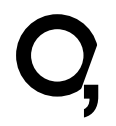



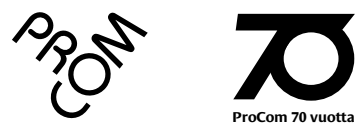

Päätoimittajat:

Elisa Juholin, dosentti, Helsingin yliopisto \& Jyväskylän yliopisto

Vilma Luoma-aho, viestinnän johtamisen professori, Jyväskylän yliopiston kauppakorkeakoulu

Toimituskunta:

Hannu Nieminen, dekaani, Helsingin yliopisto

Erkki Karvonen, professori, Oulun yliopisto

Kirsi Eräranta, apulaisprofessori, Aalto-yliopisto

Tuula-Riitta Välikoski, yliopistonlehtori, Tampereen yliopisto

Elina Melgin, toimitusjohtaja, ProCom - Viestinnän ammattilaiset ry

Tuotanto:

Minna-Liisa Nurmilaakso, viestintäpäällikkö, ProCom - Viestinnän ammattilaiset ry

Ulkoasu ja taitto:

Virpi Vihervuori, Baasis Design

Jakelu:

Julkaisu on maksuton ProComin jäsenille, ja jakelu tapahtuu tilauspohjaisesti. Kirjaa toimitetaan laajasti myös oppilaitoksiin käytettäväksi viestintäopintojen oheismateriaalina. Osa artikkeleista julkaistaan myös www.viestijat.fi-sivustolla. Kirjaa voi myös tilata ProComista hintaan 25 euroa sisältäen postituskulut.

Kustantaja:

ProCom - Viestinnän ammattilaiset ry

Kalevankatu 30, 7. krs., 00100 Helsinki

Puh. (09) 1357775

procom@procom.fi

Koko ja paperi:

A5, 14,85 cm x $21 \mathrm{~cm}$

Munken Polar

ISSN 2343-4090

ISBN 978-952-68576-1-9

Paino:

Grano, Helsinki 2017 


\section{Mitattava viestintä}


ESIPUHE

8

MIKSI VIESTINTÄÄ MITATAAN? 12

Juholin \& Luoma-aho

SETTING SMART OBJECTIVES

26

Anne Gregory

BEST PRACTICE MEASUREMENT:

LISTENING, LEARNING, ADAPTING .. 36

Jim Macnamara

MEASUREMENT TOOLS

FOR EXPLORING ONLINE

ENGAGEMENT 44

Rebecca Dolan \& Jodie Conduit

ORGANISAATIOIDEN SISÄISEN

SOSIAALISEN MEDIAN

ANALYTIIKKA JA MITTAAMINEN 54

Anu Sivunen

DIGITAALISEN MARKKINOINTI-

VIESTINNÄN TEHOKKUUS-

MITTARISTON RAKENTAMINEN 62

Joel Järvinen
VIESTINNÄN MITTAAMINEN BIG DATAN AVULLA ............................. 74

Matti Nelimarkka ja Reijo Sund

MAINEEN MITTAAMINEN

SOMEDIALISAATION

AIKAKAUDELLA 86

Pekka Aula \& Jouni Heinonen

MITEN VIESTIÄ JA MITATA

ASIAKASLÄHTÖISYYTTÄ? 98

Hannu Saarijärvi

INTEGROITU RAPORTOINTI YRITYSVASTUUN MITTAAMISEN JA ARVIOINNIN NÄKÖKULMASTA .... 110

Hannele Mäkelä \& Johanna Kujala

VIESTINNÄN ROI- MAHDOLLISUUS

VAI MAHDOTTOMUUS? 112

Petriikka Ohtonen \& Elina Ollila

.

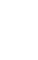


PROCOMMA ACADEMIC 2017

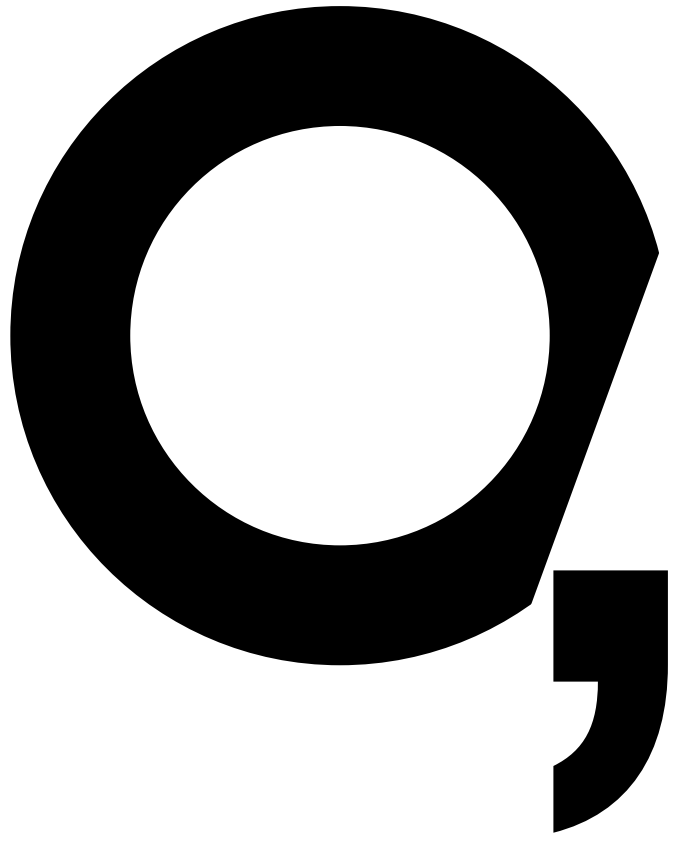




\section{O, $/ 10$}

\section{Servetulaa \\ PROCOMMA ACADEMICIN \\ T. juhlanumeroon, joka kysyy:}

\section{MITEN JA MIKSI MITTAAMME VIESTINTÄÄ?}

Viestintää pitää mitata, mutta ei sen itsensä vuoksi. Mittaaminen tuo näkyviin viestinnän arvon: onko viestinnällä riittävä yhteys organisaation strategiaan ja miten viestintä tukee itse organisaation toimintaa. Samoin on oleellista näyttää, onko resursseja käytetty tarkoituksenmukaisesti. Tässä mielessä viestintä ei eroa muista organisaation toiminnoista.

Mittaaminen on eräänlainen ikuisuusaihe viestinnän kentällä, mutta nyt sen merkitys on erityisen suuri. Digitaalinen ympäristö tuo aivan uusia vaatimuksia, mutta samaan aikaan tarjolla on uusia, innovatiivisia menetelmiä kerätä ja analysoida dataa. Toinen puoli onkin se, että dataa tulvii kaikkialla, ja tulee yhä vaikeammaksi erottaa tärkeä tieto epätärkeästä.

Perinteisesti viestintää on mitattu eri tahoille suunnatuilla kyselyillä ja media-analyyseilla, jotka peilaavat mennyttä. Käänne on tapahtunut: enää ei niinkään esitetä valmiita kysymyksiä vaan kuunnellaan avoimesti tai mennään verkkoympäristöön selvittämään, miten siellä liikutaan, toimitaan, mistä puhutaan, verkostoidutaan, ollaan vuorovaikutuksessa ja jaetaan tietoa. Katse on nykyisyydessä ja tulevassa.

ProComma Academic 4 avaa mittaamiskeskustelua strategisen viestinnän eri näkökulmista. Johdantoartikkelissa avaamme mittaamisen perusasioita ja piirrämme kuvan nykyisestä mediakentästä. Tärkeintä ei ole mittaaminen vaan se, mitä tapahtuu sen jälkeen: miten tietoa hyödynnetään ja toimintaa kehitetään.

Olemme kutsuneet kokeneita ja tunnustettuja asiantuntijoita kirjoittamaan heille läheisistä teemoista uusimman tutkimustiedon pohjalta. 


\section{O, / 11}

Kansainvälisistä kirjoittajistamme Ann Gregory korostaa viestinnän tavoitteiden merkitystä mittareiden määrittelyssä. Hän avaa artikkelissaan SMART-tavoitteita eri sidosryhmien näkökulmista ja toteaa, että tavoitteet myös muuttuvat ajassa. Jim Macnamara esittelee organisaation kuuntelemisen arkkitehtuurin, jossa oleellista ei ole esittää organisaatiolähtöisiä kysymyksiä vaan kääntää katse organisaatiosta ulos: olla avoimena sille, mitä sidosryhmillä on sanottavanaan, mistä puhutaan ja millaisia odotuksia on. Rebecca Dolan ja Jodie Conduit esittävät, miten asiakkaiden sitoutumista voidaan mitata sosiaalisessa mediassa.

Anu Sivusen artikkeli keskittyy työyhteisön sosiaalisen median mittaamisen uusimpiin mahdollisuuksiin, muun muassa siihen, miten saada verkkokeskustelut mitattavaan muotoon ja päästä tätä kautta syvemmälle organisaatiokulttuuriin. Joel Järvinen toteaa, että monikaan organisaatio ei hyödy digitaalisen analytiikan tuottamasta datasta vaan pikemminkin hukkuu siihen. Hän rakentaa mallin markkinointiviestinnän tehokkuuden mittaamiseen. Big data tai massadata on kuuma aihe, johon kohdistuu suuria odotuksia. Matti Nelimarkka ja Reijo Sund tarjoavat laskennallisen mallin viestinnän arvon mittaamiseen suhteessa kustannuksiin.

Maine on maailmanlaajuinen ja suosittu tutkimusaihe, ja maineen mittaaminen on yleistynyt kaikenlaisissa organisaatioissa. Pekka Aula ja Jouni Heinonen tuovat siihen uuden ulottuvuuden pohtimalla somedialisaation aikakauden haasteita. Hannu Saarijärvi lähestyy asiaa asiakasnäkökulmasta ja rakentaa viestinnän ammattilaisille käsitteellisen viitekehyksen, jolla voidaan ymmärtää, arvioida ja mitata asiakaslähtöisyyttä.

Hannele Mäkelä ja Johanna Kujala käsittelevät integroidun raportoinnin (Integrated Reporting, IR) viitekehyksen yritysvastuun viestinnän näkökulmasta. IR:n tarkoitus on tarjota kokonaisvaltainen kuva yrityksen pitkän aikavälin arvonluontikyvystä olennaisen informaation avulla. Petriikka Ohtosen ja Elina Ollilan artikkeli pyrkii vastaamaan kysymykseen, miten ROI-ajattelua (Return on Investment) voidaan soveltaa viestinnän mittaamisessa ja voiko sitä. 
Haluamme kannustaa viestinnän ammattilaisia kehittämään osaamistaan mittaamisessa, avaamaan työyhteisössään rohkeasti keskusteluja mittaamisen perusteista ja käytännöistä sekä hylkäämään vanhoiksi käyneitä mittareita ja tavan vuoksi mittaamista.

Elisa Juholin \& Vilma Luoma-aho

Päätoimittajat

ProComma Academic 2017 


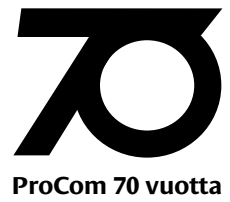




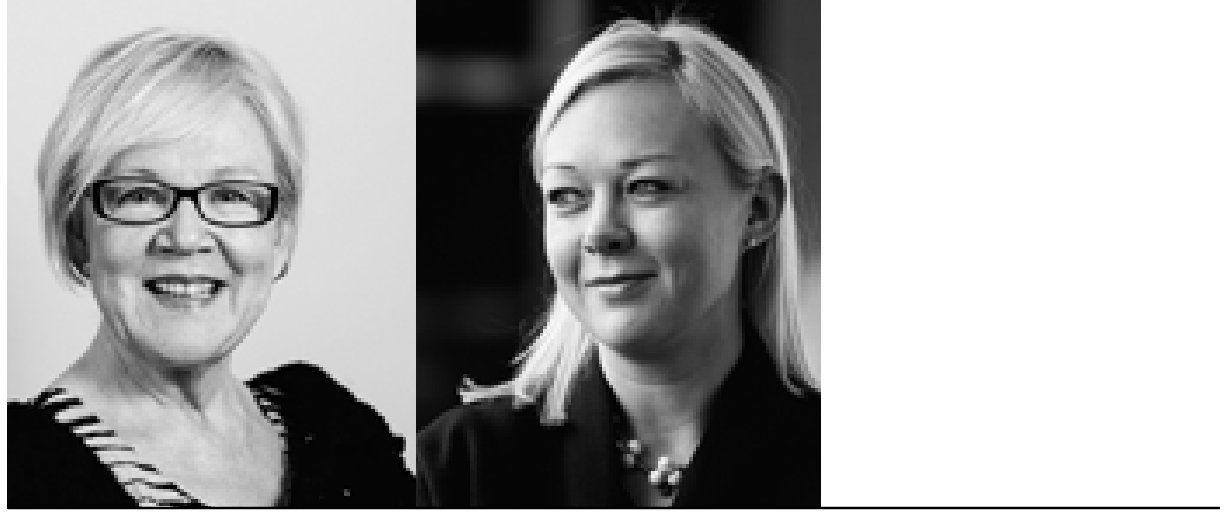

KETKÄ?

Elisa Juholin, Vilma Luoma-aho

Professori, valtiotieteiden tohtori Elisa

Juholin on Helsingin yliopiston viestin-

nän dosentti ja Jyväskylän yliopiston

yhteisöviestinnän dosentti. Hänen

erikoisalueitaan ovat strateginen

viestintä, erityisesti työyhteisöviestintä,

viestintästrategia, yritysvastuu ja

etiikka sekä viestinnän mittaaminen ja

arviointi. Juholin on Viestinnän eettisen

neuvottelukunnan puheenjohtaja.

Vilma Luoma-aho on viestinnän johta-

misen professori Jyväskylän yliopiston

kauppakorkeakoulussa (JSBE) ja

ProCom Ry:n ja Oy:n hallitusten puheen-

johtaja. Luoma-aho on Helsingin ja

Vaasan yliopistojen dosentti, työsken-

nellyt Stanfordin ja Etelä-Kalifornian

yliopistoissa, ja hän on lanseerannut

useita uusia käsitteitä kuten "luotto-

joukot" ja "teema-areenat". Parhaillaan

hän johtaa TEKES-rahoitteista sisältö-

markkinoinnin logiikkaa tutkivaa Black

Box of Content Marketing -konsortiota, ja kirjoittaa kahta oppikirjaa julkisen sektorin viestinnästä.

\section{MIKSI VIESTINTÄÄ MITATAAN?}

$V$

iestinnän mittaamista pidetään vaikeana mutta tulevaisuudessa yhä välttämättömämpänä.

Mittaaminen toimii pohjana arvioinnille. Kun viestintään suunnataan resursseja, siltä on myös lupa odottaa tuloksia. Viestinnän näkeminen strategisena voimavarana eli organisaation tavoitteiden saavuttamisen mahdollistajana edellyttää jatkuvaa tai säännöllistä arviointia. Tämä puolestaan vaatii päteviä mittareita, seurannan ja kuuntelun keinoja mutta myös kriittistä itsearviointia. Itsestäänselvyyksien eli ennalta tiedossa olevien asioiden mittaaminen on resurssien tuhlausta. Viestintäammattilaisten keskeiseksi tulevaisuuden taidoksi nouseekin kyky 
esittää viestinnän vaikuttavuus sekä numeroiden kielellä että laadullisin kriteerein. Tässä artikkelissa vastaamme kysymyksiin, miksi viestintää pitää mitata, mitä silloin arvioidaan kun arvioidaan viestintää, miten mitataan ja mitä tapahtuu mittaamisen jälkeen. Lisäksi suuntaamme katseen tulevaisuuteen ja kysymme, miten organisaatio voisi toimijana ja toiminnan kohteena saavuttaa mitattavia tuloksia hyvällä organisaation kuuntelemisella ja toimintaympäristön luotaamisella.

\section{Johdanto}

Mittaaminen kuuluu organisaatioiden johtamiseen eikä ole arvo sinänsä. Tosin sellainen siitä voi tulla, jos samaa mittausta toistetaan vuodesta toiseen ilman, että tuloksia hyödynnetään. Tämä voi johtua siitä, että mittarit eivät ole valideja eli eivät mittaa tähdellisiä asioita, tai että mittaamisesta on tullut rutiini, jolla haetaan esimerkiksi rahoittajilta tai päättäjiltä toiminnan oikeutusta.

Mittaaminen ei ole uusi asia yhteisöviestinnässä, sillä viestinnän mittaamisen arvioidaan alkaneen lähinnä mediajulkisuuden osalta Yhdysvalloissa jo 1920-luvulla (Watson, 2012). 2000-luvulla mittaaminen on saanut vain lisää haastetta yhteisöviestinnän kehittyessä strategisemmaksi (Hallahan, Holzhausen, Van Ruler, Verčič \& Sriramesh, 2007) ja toiminta- ja viestintäympäristön muuttuessa yhä vaikeammaksi ennakoida ja mahdottomaksi hallita. Organisaation on samaan aikaan arvioitava mennyttä, oltava ajan tasalla nykyhetkessä ja pyrittävä ennakoimaan tulevaisuutta ja valmistautumaan siihen (Watson \& Noble, 2008; Zerfass, Tench, Verhoeven, Verčič \& Moreno, 2011).

Talouspaineiden alla viestinnän arvon mittaamisen merkitys korostuu (Ruck \& Welch, 2012, 294). Ympäristön muuttuessa yhä viestinnällisemmäksi, haasteeksi nousee nostaa johdon mielikuvissa viestintä cost-center-ajattelusta (viestintä vaatii resursseja) revenue-centeriksi (viestintä tuottaa hyötyä), joka mahdollistaa organisaation menestyksen. Selvänä trendinä tästä siirrosta voidaan nähdä esimerkiksi viestinnän mittaaminen osana organisaatioiden kokonaistavoitteita (Watson, 2012). Pätevien mittareiden tuottama tieto auttaa priorisoimaan asioita ja suuntaamaan resurssit sinne, missä niitä eniten tarvitaan, toisin sanoen johtamaan toimintaa optimaalisella tavalla (mm. Macnamara, 2015).

Erilaiset globaalit barometrit ja selvitykset (mm. Van Ruler, Verčič \& Verčič, 2008; Watson \& Noble, 2008; European Communication Monitor, 2011, 2015; STT/ ProCom, 2016) ovat osoittaneet, että vain noin puolet organisaatioista mittaa viestintäänsä tavalla tai toisella. Luku on pysynyt suhteellisen muuttumattomana vuosikymmenestä toiseen, paitsi että mittaamisen tärkeäksi kokevien määrä on kasvanut (STT/ProCom, 2016). Viestintään kohdistuu siis tavoitteita samalla tavoin kuin mihin tahansa organisaation toimintaan tai toimintoon, joten voidaankin kysyä, miksi viestinnän mittaaminen ja arviointi eivät jo ole arkipäivää kaikissa organisaatioissa.

Viestinnän tavoitteet liittyvät usein 
aineettomiin pääomiin ja arvonluontiin, kuten maineeseen, luottamukseen, organisaatiokulttuuriin, brändiin ja odotuksiin (Kiesenbauer \& Zerfass, 2015; de Beer, 2014; Macnamara 2015). Toisaalta viestintä voi olla mukana synnyttämässä tai tuhoamassa myös aineellista pääomaa. Kriisitilanteet ovat tästä hyvä esimerkki: organisaatio voi lyhyessä ajassa menettää maksavia asiakkaita tai hyviä yhteistyökumppaneita, tai sen vetovoima työyhteisönä hiipuu. Tässä artikkelissa vastaamme kysymyksiin siitä, mitä viestinnällä voidaan saavuttaa tai menettää ja miten tätä arvioidaan.

Viestintäolosuhteiden muutos haastaa viestinnän mittaamisen ja arvioinnin ajattelutapoja ja uskomuksia. Kun tähän asti (mm. STT/ProCom, 2016; European Communication Monitor, 2015) on mitattu pääosin mediaosumia ja sidosryhmien ja henkilöstön tyytyväisyyttä, jotka edustavat melko staattista maailmankuvaa ja pikemminkin viestinnän tulemia, viime aikoina painopiste on siirtynyt yhä enemmän viestinnän vaikuttavuuteen. Halutaan siis tietää, mitä jää "viivan alle", kun tuloksista vähennetään käytetyt resurssit ja investoinnit. Vaikuttavuustuloksia ovat esimerkiksi markkinaosuus, osakekurssi, kustannussäästöt, asiakasuskollisuus, patentit, innovaatiot, lakimuutos, henkilöstön sairauspoissaolojen muutokset, varainhankinnan kehitys jne.

Markkinoinnin ja talousosaston ajatusmaailmoja on kuvailtu kahdeksi eri uskonnoksi, joiden on vaikea ymmärtää toisiaan (Suvanto-Harsaae, M\&M 5/2016). Kuitenkin edelleen monien organisaatioi- den hallitukset kuuntelevat vain numeroiden kieltä, jolloin viestintäammattilaisten uudeksi vaatimukseksi nousee osata esittää viestinnän vaikuttavuus numeroissa. Yrittäessään määrittää viestinnän luomaa arvoa viestinnän ammattilaiset nojautuvatkin etenkin taloushallinnon ja yritysjohdon piirissä paljon käytettyyn ROI-käsitteeseen (Return on Investment) (Watson \& Zerfass, 2011, 1). Yksinkertaistettuna ROI määritellään investoinnin tuottoprosentiksi (Meng \& Berger, 2012, 333; Romero 2011, 145-146). Usein tämä toteutuu käytännössä erilaisten tunnuslukujen kautta, esimerkiksi ROC (Return on Communication), ROE (Return on Expectations), ROR (Return on Relationships) ja yleisimmin näiden pääkäsite, ROI (Return on Investment). Näiden termien avulla pyritään osoittamaan se hyöty, jota viestintään suunnatuista panoksista taloudellisesti voidaan saada (Watson \& Zerfass, 2011). Yksinkertaisimmillaan ROI kertoo sijoituksen kannattavuudesta, ja sen mittaaminen pitkän aikavälin investoinneista kuten aineettomista tekijöistä on haasteellista (Meng \& Berger, 2012; Grunig, 2006). Haaste ei tosin ole ainutlaatuinen, sillä myös markkinoinnin, johtamisen ja mainonnan puolella pohditaan, miten mitata esimerkiksi ROA-lukua (Return on Advertising) tai vaikka sisäisen kulttuurin toimivuutta (Mitchell \& Makienko, 2014).

Aineettomat pääomat eivät sinänsä ole välttämättä arvokkaita, mutta niiden kautta on mahdollista lisätä tuottavuutta (Lev \& Daum, 2014). Kokonaisvaltaisen raportoinnin (Integrated reporting; http://integratedreporting.org/) myötä viestinnän 
arvon kirjaamisella on mahdollista tehdä näkyväksi organisaation aineettomia pääomia, jotka mahdollistavat tulevaisuuden menestyksen. Tällaisia ovat esimerkiksi luottamus, olemassaolon oikeutus, maine ja brändi. Uudenlainen raportointi tarjoaa sijoittajille ja osakkeenomistajille aiempaa paremman kokonaiskuvan yrityksen arvon muodostumisesta ja taloudellisesta tilanteesta.

Viestinnän mittaaminen suhteutetaan aina organisaation tavoitteisiin (Juholin, 2010/2013), sitä toteutetaan sekä lyhyellä että pitkällä aikavälillä (Meng \& Berger, 2012). Kattavin tulos saadaan hyödyntämällä sekä määrällisiä että laadullisia mittareita (Macnamara, 2015). Mediamaiseman muuttuessa mittaaminenkin muuttuu: traditionaalisen ansaitun mediasisällön ja digitaalisen omistetun median lisäksi mittaamisen tulee kohdistua jaettuun ja haettuun mediaympäristöön. Nousemassa ovat myös uudemmat louhittu ja kaapattu mediaympäristö. Kuvio 1 havainnollistaa viestinnän mittaamisen kokonaiskenttää (kaavio seuraavalla sivulla).

\section{Mitä pitäisi mitata?}

Viestinnän mittaamisen tekee haasteelliseksi se, että ihmistieteenä viestintä on moniulotteinen ilmiö, joka vaikuttaa kaikkialla organisaatiossa ja sen rajapinnoilla suhteessa sidosryhmiin ja erilaisiin julkisuuksiin. Tämä nostaa erityiseen asemaan kysymyksen, mitä pitäisi tai kannattaisi mitata, koska kaikkea ei voi koskaan mitata. On valittava ne viestinnän alueet, joilla on eniten vaikutusta organi- saation strategisiin tavoitteisiin. Viestintäalan kirjallisuudessa on tarjolla monenlaisia malleja ja kehikoita, jotka auttavat löytämään oikeat mittaamisen mallit ja mittarit. Sitä ennen pitää kysyä:

1) Mitä ja millaisia tuloksia viestinnällä tulisi saavuttaa?

2) Millaisia asioita viestinnän avulla voidaan estää, ehkäistä tai minimoida?

3) Millä aikavälillä tuloksia odotetaan - heti, tänä vuonna, ensi vuonna, 3 tai esimerkiksi 10 vuoden kuluttua?

4) Mitä yhteiskunnallisia tai muita muutoksia tulee seurata ja keitä meidän tulee kuunnella?

Mittaaminen ja arviointi vaativat kokonaisvaltaista otetta yksityiskohtien sijaan, jollaisia ovat esimerkiksi strategisista tavoitteista irrallaan oleva mediaseuranta. Viimeksi mainitussa lasketaan millimetrejä ja sekunteja sekä huomioarvot: kuinka moni huomasi, klikkasi tai tykkäsi. Nämä ovat suuntaa-antavia tuloksia mutta eivät sellaisinaan kerro paljonkaan eivätkä ennusta tulevaa. Toinen kiistelty mittari on AVE-arvo (Advertising Value Equivalency), jossa mediajulkisuus kerrotaan mainonnan kustannuksella ja saadaan julkisuuden "arvo". On myös esitetty tämän kertomista kolmella, koska journalistista julkisuutta sekä positiivisena että negatiivisena pidetään vaikuttavampana kuin maksettua julkisuutta (Watson \& Noble, 2008). 
Kuvio 1. Viestinnän mittaamisen kokonaiskenttä.

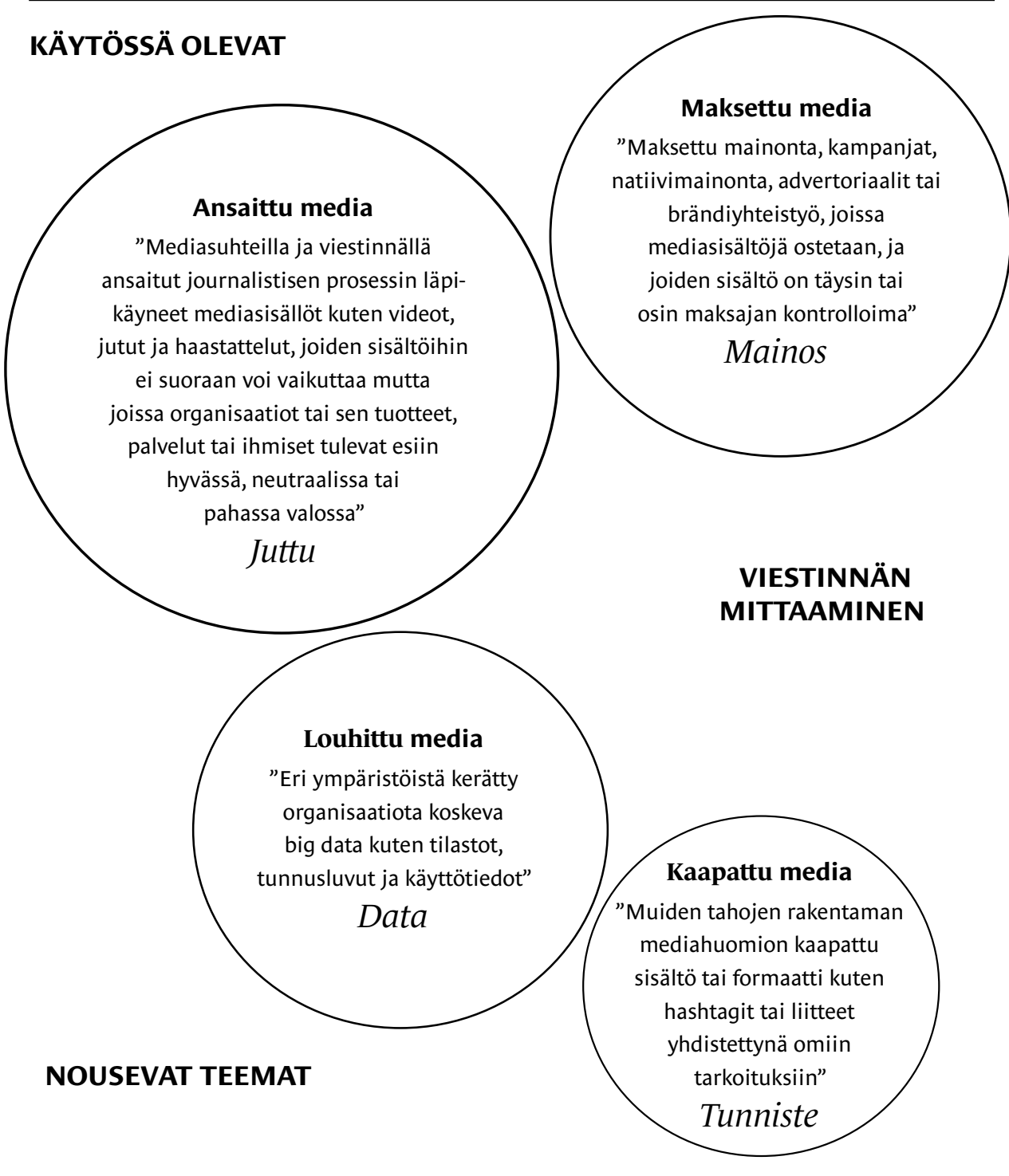




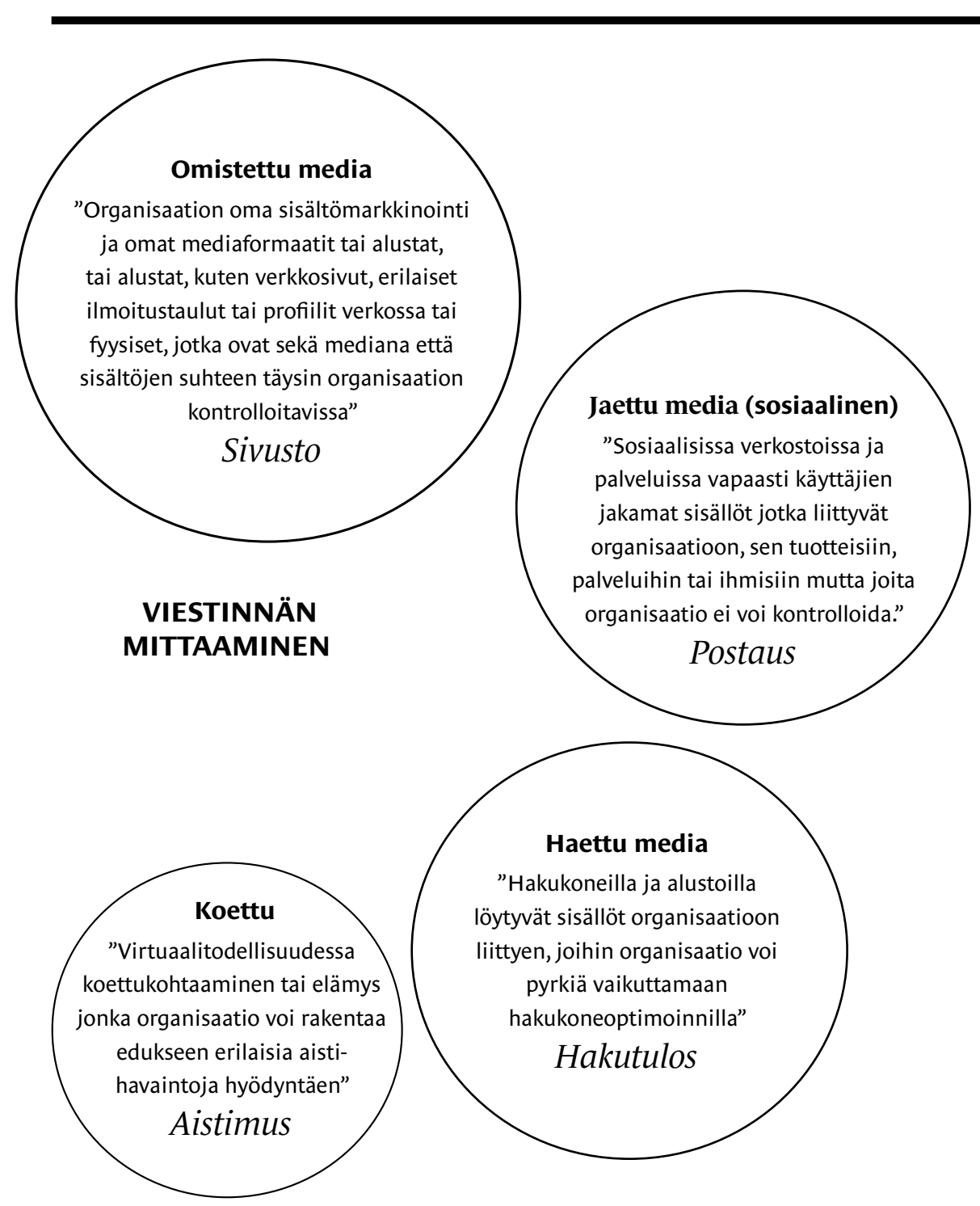


Viime vuosien tunnetuimpiin kokonaisvaltaisiin malleihin kuuluvat European Communication Monitorin (ECM) esittämä malli (2011) ja AMECin (International Association for the measurement and evaluation of communication) esittämä ruudukko nimeltään Barcelona Declaration of Measurement Principles (2011). Kumpikin malli perustuu ajatukseen, että viestinnällä voidaan saavuttaa sekä aineettomia että aineellisia tuloksia, ja että kognitiivisilla eli tiedollisilla seikoilla on merkittävä rooli. Viimeksi mainittu korostaa perustellun faktatiedon merkitystä yhteisöviestinnässä.

ECM-mallissa on neljä porrasta: Ensimmäinen on viestintään suunnatut panokset ja suunnittelun oikeaan osuvuus (input) suhteessa viestinnän nykytilaan ja organisaation kokonaistavoitteisiin. Toisella tasolla tarkastellaan välitöntä tulosta, jossa arvioidaan oman toiminnan laatua ja tehokkuutta sekä välittömiä reaktioita sidosryhmissä tai julkisuuksissa (output). Kolmannella tasolla mitataan varsinaisia viestinnän tuloksia eli esimerkiksi muistamista, kiinnostusta, suosittelua tai muutoksia sidosryhmien tiedoissa, mielipiteissä, asenteissa tai motivaatiossa (outcome). Neljännellä tasolla ovat lopulliset tulokset (outflow), jotka edustavat vaikuttavuutta ja jotka on määritelty viestinnän strategisina tavoitteina. Nämä voivat olla aineellisia tai aineettomia ja koko organisaation tuloksia ja arvoketjua.

Barcelona-malli edustaa perinteisempää lähestymistä ja perustuu viestinnän avainalueisiin, kuten brändi- ja tuotemarkkinointi, maineen rakentaminen, teemojen johtaminen, vaikuttajaviestintä, henkilöstön sitoutuminen, sijoittajasuhteet, kriisiviestintä, yhteiskuntavastuu ja yhteiskuntasuhteet. Kullekin näistä määritellään omat tavoitteensa ja mittarinsa koskien mm. viestinnän tai viestien huomaamista, sidosryhmien tietoisuutta, ymmärrystä, kiinnostusta, tukea tai valinnan ensisijaisuutta sekä konkreettisia valintoja tai toimintaa. Vuonna 2015 julkaistu päivitys Barcelona 2.0 korostaa, että viestinnän mittarit tulee sitoa sekä viestinnän tavoitteisiin että koko organisaation tavoitteisiin, mikä tarkoittaa, että pelkkiin välittömiin reaktioihin ei tule kiinnittyä eikä tukeutua liiaksi. Mittaamisessa tulisi hyödyntää määrällisten mittareiden rinnalla laadullista lähestymistä ja mittareiden validiteettiin sekä mittausprosessien läpinäkyvyyteen pitää kiinnittää erityistä huomiota. (AMEC, 2015.) Viimeksi mainittu on erittäin aiheellinen huomio digiaikana, jolloin tulosten manipulointi on entistä helpompaa.

\section{Millä mittareilla?}

Mittareita voidaan tarkastella ja luokitella monin tavoin sen mukaan, halutaanko määrällistä vai laadullista tutkimusta; poikittais- vai pitkittäistutkimusta; laajoja otoksia vai rajattu näyte; sekä onko tarkoitus selvittää mennyttä, nykyhetkeä vai tulevaa, vai kaikkea näitä. Mittareiden määrä voi kasvaa suureksi, mikäli kenelläkään organisaatiossa ei ole kokonaiskuvaa siitä, mitä kaikkea mitataan ja millä mittareilla. Mittareiden inventaarion tarkoitus on koota tieto käytössä olevista mittareista ja niiden niveltymistä koko organisaation 
ja viestinnän tavoitteisiin. Tämä auttaa tunnistamaan parhaimmat mittarit sekä karsimaan pois epävalidit tai päällekkäiset. (Juholin, 2010/2013.)

Menneestä saadaan tietoa kysymällä asioita sidosryhmiltä tai analysoimalla esimerkiksi tekstejä ja mediajulkisuutta. Paljon käytettyjä mittareita ovat survey- eli kyselytutkimukset, haastattelut, paneelit ja pienryhmäkeskustelut. Näissä luotetaan siihen, että vastaajat tai haastateltavat puhuvat totta, vaikkakin usein vastaavat sosiaalisesti suotavalla tavalla (Vehkalahti, 2008). Etnografiset eli ihmisten ja kulttuurien tutkimukseen liittyvät menetelmät ovat vahvasti tulossa myös organisaatioihin. Etnografisessa tutkimuksessa tai ns. uusissa small-data-tutkimuksissa strategiana on kuvata ja selittää ihmisten toimintaa heidän omassa ympäristössään seuraamalla heidän arjen toimintaansa ja valintojaan ja niiden kautta kehittää organisaation tuotteita ja palveluita (Lindstrom, 2016).

Nykyisyyttä seurataan esimerkiksi sosiaalista mediaa kuuntelemalla tai analysoimalla julkista keskustelua: mikä ihmisiä kiinnostaa, ilahduttaa, raivostuttaa ja millaisia odotuksia heillä on (Luoma-aho \& Olkkonen, 2016). Voidaan ajatella, että jokainen asiakasvalitus on mittari pieleen menneestä odotustenhallinnasta (Luoma-aho, 2016). Odotuksien seuraaminen on parhaimmillaan reaaliaikaista, heikkojen signaalien lukemista, jolloin voidaan reagoida tarvittaessa nopeastikin nouseviin haasteisiin tai korjata suuntaa kesken matkan.
Tulevasta pyritään saamaan selkoa erilaisin ennakointi- ja kuuntelumenetelmin, esimerkiksi rakentamalla organisaatioon "kuuntelemisen arkkitehtuuri" (Macnamara, 2015). Tämä arkkitehtuuri kääntää perinteisen ajattelun ylösalaisin: kuuntelemalla asiakkaita voidaan kehittää palveluja ja tuotteita, ja kuuntelemalla henkilöstöä pystytään parantamaan prosesseja ja kannattavuutta. Tämä edellyttää, että organisaatiot luopuvat perinteisestä tavasta määritellä itse, mitä ja milloin sekä keitä halutaan kuulla, ja sen sijaan antaa ääni tahoille ja asioille, joita ei ennakkoon tunneta (ks. Macnamaran artikkeli tässä julkaisussa). Tällä tavoin voidaan päästä käsiksi ennalta-arvaamattomaan pikkutarkkaankin tietoon, joka voi avata täysin uusia mahdollisuuksia (Lindstrom, 2016).

Vaikka nopeita ratkaisuja viestinnän mittaamiseen on vähän, on joitain yksinkertaisempia viestinnän mittareitakin tarjolla: liiketalouden puolelta tuttu NPS (Net Promotor Score) (Reichheld, 2003, 2011) -luvulla mitataan suosittelijoiden osuutta kaikista sidosryhmistä yhdellä kysymyksellä: "Voisitko suositella organisaatiota X eteenpäin muille?" Luottojoukkoajattelussa kartoitetaan erotusta luottojoukkojen ja vihajoukkojen määrän välillä: legitimiteetti säilyy vain, jos luottojoukkoja (positiivisia sidosryhmiä) on enemmän kuin vihajoukkoja (negatiivisia sidosryhmiä) (Luoma-aho, 2015).

Seuraavalla sivulla oleva taulukko pyrkii selkiyttämään muutamin esimerkein mittareiden suuria luokkia, mikä helpottaa yksittäisten mittareiden tarpeen ja tehtävän määrittelyssä. 
Taulukko 1. Mitä viestinnässä mitataan ja arvioidaan?

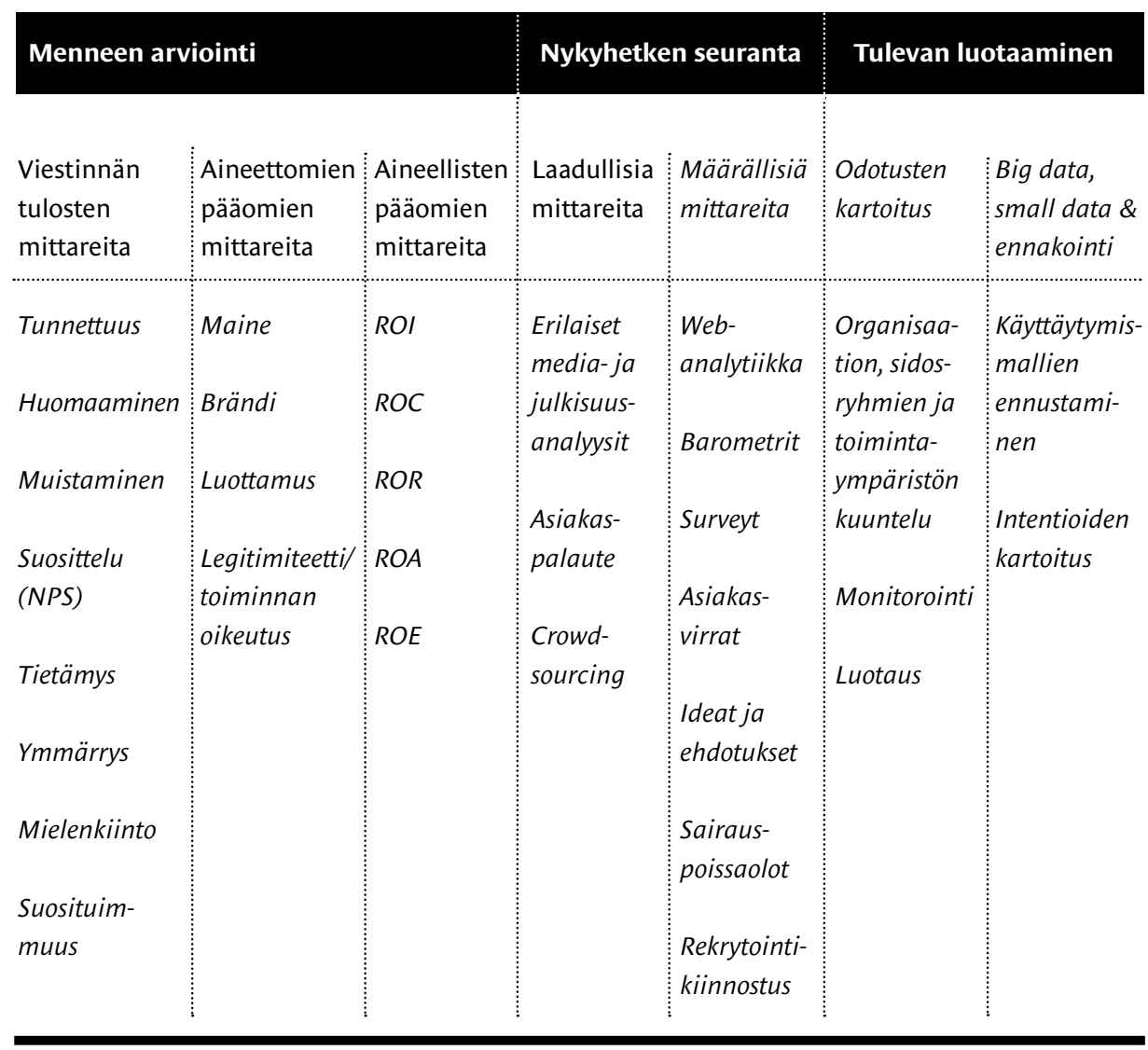




\section{Mitä tuloksilla tehdään?}

Mittaamisprosessin tärkein vaihe on se, kun tulokset ovat käsillä ja pitää päättää, mitä niillä tehdään. Mittaamisen pohjalta tehdään arviointi siitä, mitä nämä tulokset kertovat ja mitä niiden perusteella pitäisi tehdä. Verrataanko tuloksia aiempiin omiin tuloksiin, sidosryhmien odotuksiin vai esimerkiksi toimialaan tai kilpailijoihin? Jos tulokset eivät ole odotetunlaiset, tulee kiusaus siirtää julkistamista tai jopa luopua siitä kokonaan tai mitätöidä tulosten merkitystä. Näin toimittaessa seuraaviin kyselyihin tai barometreihin on entistä vaikeampi saada vastaajia ja ylipäätään ihmisiä pohtimaan parempaa tulevaisuutta. Tunteenomainen suhtautuminen tuloksiin vie pohjaa kehittämiseltä ja loukkaa niitä henkilöitä, jotka ovat antaneet aikaansa vastaamalla kyselyyn tai muuten osallistumalla tutkimukseen.

Kehittämisen tulee olla yhteisöllinen prosessi, jossa mahdollisimman moni osallinen pääsee kuulemaan, keskustelemaan, ottamaan kantaa ja ehdottamaan, miten asioita voidaan ja kannattaa entisestään parantaa. Syklimäisyys korostaa organisaation toiminnan jatkuvuutta, johon arviointi kytkeytyy luonnollisena osana. Arviointi ja kehittäminen eivät saa jäädä pelkäksi keskusteluksi vaan vaativat pätevää dokumentaatiota prosessin vaiheista, osallistujista ja sisällöistä. Yksi tapa kehittää eteenpäin saatuja tuloksia on järjestää "Fit or Fix"-sessio johtoryhmän tai muun kehittäjätahon kanssa, jossa käydään läpi eri viestinnän mittaustulokset ja harkitaan, tulisiko organisaation korjata vastaajien käsityksiä odotustenhallinnan avulla
(Fit) vaiko muuttaa itse toimintaansa paremmaksi (Fix) (Luoma-aho, Olkkonen \& Lähteenmäki, 2013).

\section{Lopuksi: Mittaamisen seitsemän viisautta}

Vaikka viestinnän mittaamisen kenttä on laaja, on tiettyjä askeleita, joita aina kannattaa noudattaa. Seuraavassa listaamme 7 best practice -ajatusta.

1. Linkitä kaikki mittaaminen organisaatiosi strategisiin tavoitteisiin ja toimintaympäristön muutoksiin tai näkymiin. Korosta alituiseen johdolle strategisen viestinnän ja sen mittaamisen merkitystä.

2. Tee mittaamisesta näkyvä asia: kerro etukäteen, mihin tarkoitukseen tietoa kerätään ja analysoidaan, ja mihin tietoa hyödynnetään. Tällä tavoin saadaan rekrytoitua vastaajia ja osallistujia.

3. Huolehdi tutkimusetiikasta eli että luottamukselliseksi luvatut aineistot pysyvät luottamuksellisina.

4. Julkista tulokset näyttävästi ja pidä tuloksia näkyvillä omilla sivuilla.

5. Kutsu ihmisiä mukaan tulosten jälkeiseen kehittämiseen ja palkitse kehittämistyöstä.

6. Julkista, mitä päätöksiä, suunnitelmia ja konkreettisia muutoksia tulee tapahtumaan tulosten perusteella. Osoita niiden toteutuessa linkki tutkimuksiin. 
7. Inventoi esimerkiksi kerran vuodessa organisaatiossasi käytössä olevat mittarit ja arvioi niiden tarpeellisuutta ja pätevyyttä. Luovu turhista mittareista.

\section{Näistä voit aloittaa:}

1) IPR - Institute for Public Relations (2015). Barcelona Principles 2.0 - Updated 2015.

Saatavilla verkossa: http://www.instituteforpr.org/barcelona-principles-2-0-updated-2015/Viestinnän mittaamisen periaatteet pähkinänkuoressa englanniksi.

2) Zerfass, A., Tench, R., Verhoeven, P., Verčič, P. \& Moreno, A. (2015). European Communication Monitor 2015. Creating communication value through listening, messaging and measurement. Results of an Empirical Survey in 41 Countries. Brussels: EACD, EUPRERA, Helios Media.

3) Macnamara, J. (2015). Creating and Architecture of Listening in Organizations. Saatavilla verkossa: https://www.uts.edu. $\mathrm{au} /$ sites/default/files/fass-organizationallistening-report.pdf

Kuuntelemisen arkkitehtuurin rakentamisen periaatteet tutkimusprojektin tuloksien väliin puettuna englanniksi.

\section{LÄHTEET}

Cornelissen, J. (2011). Corporate Communication: Theory and practice. 3. painos. London: Sage.
Cornelissen, J. (2008). Corporate Communication. The International Encyclopedia of Communication. Donsbach, Wolfgang (toim.) Blackwell: Blackwell Publishing. Saatavilla verkossa: <http://www.communicationencyclopedia.com/ subscriber/tocnode.html?id=g9781405131995_ yr2014_chunk_g97814051319958_ss144-1 >. 21.11.2015.

Cornelissen, J., van Bekkum, T. \& van Ruler, B. (2006). Corporate Communications: A Practice-based Theoretical Conceptualization. Corporate Reputation Review 9(2), 114-133.

de Beer, E. (2014). Creating value through communication. Public Relations Review 40(2), 136-143.

ECM - European Communication Monitor (2015). ECM 2015 Chart Report. European Public Relations Education and Research Association \& European Association of Communication Directors. Saatavilla verkossa: http://www. zerfass.de/ECM-WEBSITE/media/ECM2015Results-ChartVersion.pdf. Luettu 6.11.2015.

ECM - European Communication Monitor (2010). ECM 2010 Chart Report. European Public Relations Education and Research Association \& European Association of Communication Directors. Saatavilla verkossa: http://www. zerfass.de/ECM-WEBSITE/media/ECM2010Results-ChartVersion.pdf. Luettu 6.11.2015.

Grunig, J. (2006). Furnishing the Edifice: Ongoing Research on Public Relations As a Strategic Management Function. Journal of Public Relations Research 18(2), 151-176. 
Hallahan, K., Holzhausen, D., Van Ruler, B., Verčič, D. \& Sriramesh, K. (2007). Defining Strategic Communication. International Journal of Strategic Communication 1(1), 3-35.

Stacks, D. \& Bowen, S. (2013). Dictionary of Public Relations Measurement and Research. Institute for Public Relations. 3. painos. Saatavilla verkossa: http://www.instituteforpr.org/ wpcontent/uploads/Dictionary-of-Public-Relations-Measurement-and-Research-3rd-Edition. pdf. Luettu 16.11.2015.

IPR - Institute for Public Relations (2015). Barcelona Principles 2.0 - Updated 2015. Saatavilla verkossa: http://www.instituteforpr. org/barcelona-principles-2-0-updated-2015/. Luettu 5.11.2015.

Juholin, E. (2010/2013). Arvioi ja paranna! Viestinnän mittaamisen opas. Helsinki: Infor. Helsinki: Talentum.

Kiesenbauer, J. \& Zerfass, A. (2015). Today's and tomorrow's challenges in public relations: Comparing the views of chief communication officers and next generation leaders. Public Relations Review, 41(4) ,422-434.

Kim, Y. \& Yan, J. (2013). Corporate Reputation and Return on Investment (ROI): Measuring the Bottom-Line Impact of Reputation. Teoksessa Carroll, C. E. (toim.) Handbook of Communication and Corporate Reputation. Chicester: Wiley-Blackwell, 574-589.

Laskin, A. V. (2013). Reputation or Financial Performance: Which Comes First? Teoksessa Carroll, C. E. (toim.) Handbook of Communi- cation and Corporate Reputation. Chicester: Wiley-Blackwell .

Lev, B. \& Daum, J. (2004). The dominance of intangible assets: consequences for enterprise management and corporate reporting. Measuring Business Excellence, 8(1), 6-17.

Likely, F., Rockland, D. \& Weiner, M. (2006). Perspectives on the ROI of Media Relations Publicity Efforts. Institute for Public Relations. Saatavilla verkossa: http://www.instituteforpr. org/wp-content/uploads/2006_ROI_LRW.pdf. Luettu 30.10.2015.

Lindstrom, M. (2016). Small Data. The Tiny Clues that Uncover Huge Trends. London: John Murray Learning, St. Martin's Press.

Luoma-aho, V. \& Olkkonen, L. (2016). Expectation Management. Teoksessa Carroll, C. (toim.) The Sage Encyclopedia of Corporate Reputation. Thousand Oaks, CA: Sage Publications, 303-306.

Luoma-aho, V. (2015). Understanding Stakeholder Engagement: Faith-holders, Hateholders \& Fakeholders. Research Journal of the Institute for Public Relations 2(1). Saatavilla verkossa: http:// www.instituteforpr.org/understanding-stakeholder-engagement-faith-holders-hateholders-fakeholders/

Luoma-aho, V., Olkkonen, L. \& Lähteenmäki, M. (2013). Expectation management for public sector organizations. Public Relations Review 39, 248-250.

Luoma-aho, V. (2016). Särkymättömämpää viestintää. Keynote-puheenvuoro, Valtioneuvoston 
kanslian viestintäsuositus VISU2016 -seminaari, Helsinki, 6.6.2016. Saatavilla verkossa: https://prezi. com/bvufkd762j-3/sarkymattomampaa-viestintaa/ Macnamara, J. (2016). Organizational listening. University of Technology Sydney.

Macnamara, J. (2015). Breaking the measurement and evaluation deadlock: A new approach and model. Journal of Communication Management 19(4), 371-387.

Macnamara, J. (2000). The 'Ad Value' of PR. Asia Pacific Public Relations Journal 2(1), 99-104.

Maier, F., Schober, C., Simsa, R. \& Millner, R. (2015). SROI as a Medhod for Evaluation Research: Understanding Merits and Limitations. Voluntas, 26, 1805-1830.

Meng, J. \& Berger, B. K. (2012). Measuring return on investment (ROI) of organizations' internal communication efforts. Journal of Communication Management 16(4), 332-354.

Michaelson, D. \& Stacks, D. W. (2011). Standardization in Public Relations Measurement and Evaluation. Public Relations Journal 5(2).

Millar, R. \& Hall, K. (2013). Social Return on Investment (SROI) and Performance Measurement. Public Management Review 15(6), 923-941.

Mitchell, T. \& Makienko, I. (2014). Beyond the Return on Advertising: Elasticity of the Return on Advertising as a Diagnostic Metric to Maximize Profit. Journal of Promotion Management 20(2), 250-265.
Olkkonen, L. \& Luoma-aho, V. (2014). Public Relations as expectation management? Journal of Communication Management 18(3), 222-239. Reichheld, F. (2003). The One Number You Need To Know To Grow. Harvard Business Review December 2003.

Reichheld, F. F. \& Markey, R. (2011). The Ultimate Question 2.0: How net promoter companies thrive in a customer-driven world. Harvard Business Press.

Roloff, J. (2008). Learning from multi-stakeholder networks: issue-focussed stakeholder management. Journal of Business Ethics 82, 233-250.

Ruck, K. \& Welch, M. (2012). Valuing internal communication; management and employee perspectives. Public Relations Review 38(2), 294-302.

Stacks, D. W., Dodd, M. D. \& Men, R. (2013). Corporate Reputation Measurement and Evaluation. Teoksessa Carroll, C. E. (toim.) Handbook of Communication and Corporate Reputation. Chicester: Wiley-Blackwell, 561-573.

STT Viestintäpalvelut, ProCom (2016). Viestinnän mittaamisen tila suomalaisissa organisaatioissa. Helsinki: IRO Research.

Van Riel, C. B. M. (1995). Principles of Corporate Communication. London: Prentice Hall.

Van Ruler, B., Verčič, A. \& Verčič, D. (toim.) (2008). Public Relations Metrics. Research and Evaluation. New York: Routledge. 
Vehkalahti, K. (2008). Kyselytutkimuksen mittarit ja menetelmät. Helsinki: Tammi.

Vos, M., Schoemaker, H. \& Luoma-aho, Vilma. (2014). Setting the agenda for research on issue arenas. Corporate Communications 19(2), 200-215.

Vos, M. \& Schoemaker, H. (2004). Accountability of Communication Management. Utrecht: Lemma Publishers.

Watson, T. (2012). The evolution of public relations measurement and evaluation. Public Relations Review 38(3), 390-398.

Watson, T. (2011). An initial investigation on the use of 'Return on Investment' in public relations practice. Public Relations Review 37, 314-317.

Watson, T. \& Zerfass, A. (2011). Return on investment in public relations: A critique of concepts used by practitioners from communication and management sciences. Prism 8(1). Saatavilla verkossa: : http://www.prismjournal. org/homepage.html

Watson, T. \& Noble, P. (2008). Evaluation Public Relations. A Best Practice Guide to Public Relations Planning, Research and Evaluation. London: Kogan Page.

Zerfass, A., Tench, R., Verhoeven, P., Verčič, P. \& Moreno, A. (2011). European Communication Monitor 2010. Status Quo and Challenges for
Public Relations in Europe. Results of an Empirical Survey in 46 Countries. Brussels: EACD, EUPRERA

\section{MUUT LÄHTEET}

Suvanto-Harsaae, S. (2016). Markkinointi ja talousosasto ovat kuin kaksi eri uskontoa. Markkinointi \& Mainonta 5/2016, 16-17. 


\section{O, 128}

WHO?

\section{Anne Gregory}

- Anne Gregory, PhD, HonFCIPR, FRSA, FHEA, is Professor of Corporate Communication at the University of Huddersfield. After working as a journalist for the $B B C$ and independent radio, Anne spent 12 years as an award winning practitioner at senior levels. She is now an internationally recognised communication scholar having authored and edited over 25 books, 100 journal and professional articles and book chapters and a number of international research initiatives.

SMART OBJECTIVES

AND MEASUREMENT: THE VIRTUOUS CIRCLE

\section{$\neg$ he following chapter looks at the importance of setting SMART objectives in commu-} nication programmes and campaigns. This is important because the communication planner needs to be able to demonstrate:

- the value of their work (how it helps the organisation achieve its objectives)

- its impact (what changes as a result of communication)

- effectiveness (that their interventions have achieved what they were intended to)

- efficiency (that resources have been used well) 
The chapter covers the crucial link between objectives and evaluation, how objectives fit into the planning cycle, the link between aims and objectives, the different levels of objectives, the different types of objectives and finally, constraints on objective setting.

\section{Introduction}

In recent years there has been an increasing focus on the need for communication planners to evaluate their work in order to demonstrate it is both effective and efficient (Gregory, 2015; Noble, 2014). In the private sector this has been driven by increasing scrutiny of costs within organisations and a demand for a good Return on Investment (Likely \& Watson, 2013; Macnamara 2014). In the public sector communication has come under increasing pressure because of budget restraints in spending post the financial crisis of 2008/9 and because of calls for greater transparency from citizens (Gregory, 2017; Macnamara, 2017).

In response the communication industry itself has come forward with numerous initiatives to improve and standardise evaluation metrics and measures the most well-known of which are those produced by the International Association for the Measurement and Evaluation of Communication (AMEC). The Barcelona Principles first introduced by AMEC in 2010 and revised in 2015 (AMEC, 2010, 2015) are often regarded as the point at which thinking on evaluation and measurement began to coalesce.
Strategic communication planning models through the history of communication planning (for example, Cutlip, Center and Broom, 1985; Lindenmann, 1993: Fairchild, 1997; Watson, 1997, Macnamara, 2002; Gregory, 2015; Government Communication Service (GCS), 2016) all follow the same logic with the basic format following a five step process: define aims and objectives; determine what the desired outcomes are; devise strategies to achieve those outcomes; set measures and targets, and review the results. All agree that it is impossible to judge success if there is no recognition of the starting point of the journey and the distance that has to be travelled.

All the literature agrees that evaluation begins at the start of the planning cycle, with the setting of measurable objectives. Measurement and evaluation against defined goals and SMART objectives are fundamental to any communication programme whether it be a single campaign or an on-going effort where the results are incremental over time. (AMEC, 2015, p.2). The fundamental principle of starting with goals and SMART objectives is also fully supported in the public sector with the European Commission (Henningsen et al, 2014) stating this as 'a baseline for best practice communication measurement and evaluation' (p.1).

\section{SMART objectives and prior research}

Setting SMART communication objectives requires prior work on a number of key factors: 
Identifying the issue

As Grunig and Hunt identified back in 1984 (Grunig \& Hunt, 1984) all effective communication programmes address issues. Issues create aware and active publics and these are the primary groups that organisations need to engage with. These issues can be opportunities as well as potential and actual problems with particular stakeholder groups. Issues are wide-ranging and caused because relationships with groups are created, changed or ended in a way that generates a reaction, whether that be at the level of attitudes, feelings or behaviour. There are also issues that pose reputational risks, issues created by changes in the environment or by association with a particular sector such as the pharmaceutical industry. Research and analysis is required to identify the issues on which to base any communication programme.

\section{Uncovering stakeholder perceptions and behaviours}

Analysis may or may not include a thorough investigation of both the external and internal environment, but invariably a key component is a careful examination of publics and stakeholders to discover their attitudes towards the organisation itself and to the wider issue identified. Crucial to this is listening, understanding and seeing the world from the stakeholder point of view and not taking an instrumental approach where people are there to be 'researched' in order to be persuaded and manipulated for purely organisational gain.
Determining the communication contribution. Having identified the issue or problem, the planner then has to determine how communication can contribute to its resolution. Windahl et al. (2009) define a communication-based problem in two ways: first, a problem may arise from the lack of or wrong sort of communication. For example, winter flu vaccination is not being requested by older people because it has only been announced to doctors (lack of information) and because it has been described by its technical name (wrong sort of information) - this problem can easily be solved by communication. Second, a problem is a communication problem if it can be solved communication alone. For example, if the uptake of the vaccinations has also been affected by suspicions about its effectiveness, or if there are a limited number of clinics where it is available, then this is more than a communication problem. Some other measures such as independent opinion to confirm its effectiveness and wider availability may be needed to stimulate use. In this case the Communication professional needs to bring these problems to management attention and once they are addressed, communication can step in.

Scoping the impact communication can make The analysis stage will also identify the impact the communication activity is meant to achieve and the nature of the intervention required. For example, if the analysis discovers that only $60 \%$ of older people are taking up flu vaccinations and the Government target is $90 \%$, then, provided 
the problem can be solved by communication alone, the desired impact will be to gain compliance from an addition $30 \%$ of the target population and communication interventions that stimulate behaviour change will be required.

\section{Aims and objectives}

The author's view is that to set SMART objectives it is important to have an overarching aim for the communication plan. Sometimes there will be more than one aim if there are multiple strands to the plan and/or very different stakeholders with different agendas to engage.

The aim or aims will state what the programme seeks to achieve in overall terms. They are useful to articulate because they required focussed thinking on what the overall impact and contribution will be. They also provide the bridge to organisational aims and through them to potential societal contribution. If one organisational aim of a country's health department is to keep the elderly population healthy and active for as long as possible, then communication activity must be focused on that. Not only does the vaccination communication contribute to the organisation meeting its objectives, but it also taps into wider societal values about looking after older people who have contributed to a country's prosperity over their lifetime.

A good aim should be able to be evaluated at the end of the programme by turning it into a question. Thus, the aim 'to maximise the uptake of flu vaccination by elderly people' becomes the evaluative question 'did we maximise the uptake of the vaccine by elderly people?'.

The aim of the UK Government's GREAT campaign whose purpose is to grow the UK economy is

'to increase the levels of trade, investment and tourism, and high quality students coming to the UK, leading to a measurable economic impact of at least $£ 1$ billion over three to five years and the creation of over 10,000 direct jobs for the UK economy' (see https://gcs.civilservice. gov.uk/guidance/campaigns/case-studies/\#great)

\section{SMART objectives}

Objectives are the specific, measurable steps that break the aims into what are effectively milestones for the programme. Research on publics will have uncovered their position on any particular topic which provides a starting point, or benchmark. The planner then needs to decide what movement if any is required: a legitimate objective may be to confirm existing attitudes or actions.

SMART objectives should have a number of characteristics as spelt out by the acronym: they should be

- Specific (formulated clearly and completely understandable)

- Measurable

- Attainable (within the resources provided and not over-ambitious in scope)

- Relevant (making a contribution that is related to the task)

- Time-bound 
Examples of SMART objectives linked to specific groups of stakeholders are:

Employees: Ensure every employee is able to repeat the three key objectives in the new corporate plan by 10 November.

Corporate: Change regulations on the taxation of charitable giving within two years by influencing voting behaviour of government ministers via a lobbying campaign.

Trade: Double competitive tendering from key suppliers by increasing chief executive to chief executive meetings by $50 \%$

Consumer: Increase numbers of consumers who say they are more aware of us than our main competitors from $60 \%$ to $70 \%$ in 18 months.

Objective setting is complex (Noble, 2014; Watson \& Noble, 2014). Communication exists within a dynamic context and sits alongside other activities that may shape attitudes or behaviour over time such as shifts in public opinion, changes in government policy, significant public trends and events (for example BREXIT) all of which may also stimulate action from opposing or supporting groups. Setting communication objectives in this environment is difficult, nonetheless, unless some attempt is made to set SMART objectives, it will be virtually impossible to measure progress or evaluate the eventual outcome.

\section{Levels of objectives}

It is generally accepted (IPR, 1997, 2003; Gregory, 2015; Macey \& Schneider, 2008; Stacks \& Bowen, 2010; Watson \& Noble, 2014) that objectives and outcomes of communication are formulated at three levels:

- Cognitive objectives seek to create awareness and understanding. They deal with information and knowledge, focus on providing the thinking element of the content and on what information publics should know, understand and remember.

- Affective objectives deal with how people react to information. This focuses on the feeling elements of the content and on what emotional response is generated. This affects interest and attitudes

- Conative objectives deal with the hoped-for response. This focuses on the behavioural outcomes that might be generated when people are exposed to the content of the programme.

The table next page shows examples of these types of objectives. 
Table 1. Examples of three levels of objectives

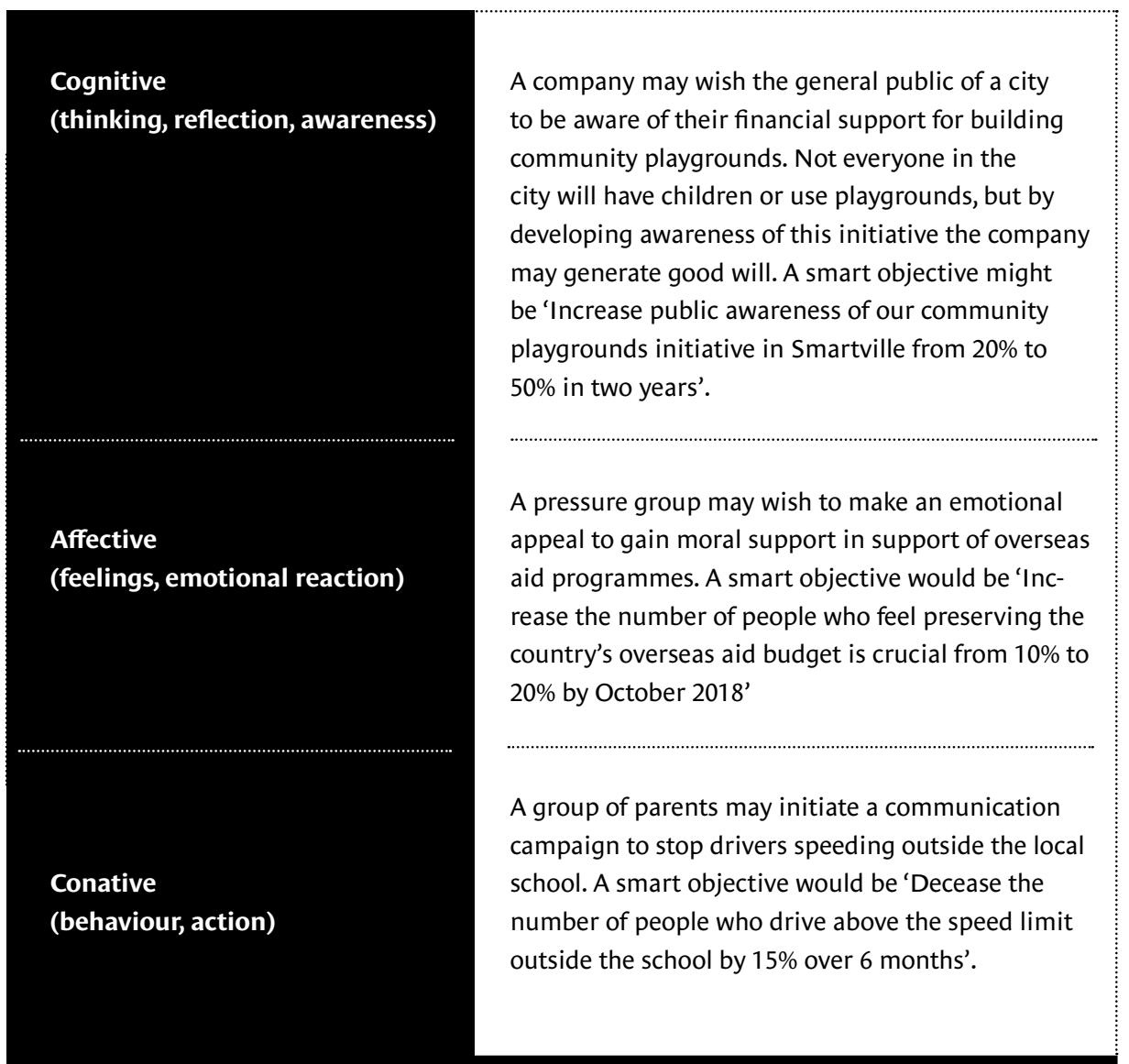


The choice of level of objectives is determined by two factors: the effect desired by communication planners and the starting point of the group who are the targets of the communication. Behaviour change is generally more difficult to achieve because of the level of personal investment that is required. The three levels are often regarded as hierarchical (Noble, 2014), with behaviour change not being possible without a degree of awareness and motivation.

According to Grunig and Hunt (1984) three variable make the achievement of objectives easier:

- the level of effect (or outcome) should be chosen with care. If the communication planner wants to induce radical change, it will be sensible to set cognitive objectives first, rather than hoping for conative effects from the start.

- choose target publics with advocacy in mind. Research should have identified those who already support the position of the organisation; they can then act as advocates on its behalf.

- organisations can change too. Sometimes minor adjustments in the organisation's stance can elicit a major, positive response from publics.

Recent advances in behavioural economics (Thaler \& Sunstein, 2008; Nesterak, 2014) have been enthusiastically embraced by Governments across the world, including in Britain, Australia and the US who have been using social psychological techniques to accelerate the time needed to achieve in behaviour change.

\section{Types of objectives}

In the author's experience of judging Awards, communication programme objectives often describe the process, that is, what the planner will do, rather than the desired outcome or impact of the communication. These are very different types of objectives. In the example given above about corporate objectives (change regulations on the taxation of charitable giving within two years by influencing voting behaviour of government ministers via a lobbying campaign) the impact of the communication is aimed at changing the regulations. The process is through a lobbying campaign.

When framing SMART objectives, impact should always come first since that is about framing the desired outcome. That element will remain constant. The process may change once the programme is underway and the effectiveness and efficiency of the process is monitored and evaluated. For example, the planner may find lobbying is too expensive and time consuming and that working through the trade body is better in both respects. Thus process is more concerned with management rather than outcomes.

Furthermore, when evaluating communication programmes it is the impact or outcome that determines whether the programme has been ultimately successful or not. Thus, in the example given above, what really matters is whether the regula- 
tions were changed. Usually process objectives are measured at the output level and would be concerned with measuring such matters as the number of times Ministers were met, what there voting intensions were, the amount of press coverage for your programme and whether it was positive or negative. While important they are not as important as the result, they are means to obtaining the result.

\section{Constraints on objectives}

While objectives should be SMART, sometimes it is not always possible to be precise about timeframes or the level of change that might be achieved. Programmes designed to achieve social change, such as shifts in attitudes and behaviour on food consumption or towards immigration are notoriously difficult to gauge. It is then that a nuanced and agile (van Ruler, 2014) approach is called for where constant monitoring of the environment and the programme is needed and objectives recalibrated as the evidence-base is built up.

There are other constraints to be borne in mind too such as the capability and capacity of those involved in implementation, the resources available, the support of senior people and infrastructure, changes in the external environment and in key stakeholder groups. This points to the fact that irrespective of the accuracy of the issue-identification and of the SMARTness of the objectives devised, communication is about human attitudes, feelings and behaviours. These can never be completely predicted or understood. Which means that a level of humility and a great deal of listening is required by those involved in setting objectives.

\section{Conclusions}

Setting sound aims and objectives is fundamental to communication planning. They define what the outcomes of the programme will be, they provide the rationale for the strategy, set the agenda for tactical actions and are the benchmark against which the programme will be evaluated. Their importance cannot be overstated.

To conclude this chapter on SMART objectives there are a number of Golden Rules which can be incorporated into practice immediately:

1. Setting SMART Objectives are an essential part of a professional approach to programme planning

2. Good objectives are based on sound research which discovers:

a. the issues upon which a communication programme should be based,

b. the awareness, attitudes and behaviours of the key stake holders involved,

c. the contribution of communication to resolving those issues, and

d. the size of the communication task

3. Setting SMART objectives are key to being able to evaluate any communication programme

4. Deciding the level of communication objectives is crucial

5. Ensuring that objectives are impact focussed is essential 
6. Understanding that objectives may have to change if circumstances change recognises the reality of today's complex environment.

\section{Online sources of information:}

IPR - Institute for Public Relations (2009). Guidelines for Setting Measurable Public Relations Objectives: An Update http://www.instituteforpr.org/wp-content/ uploads/Setting_PR_Objectives.pdf

GSC - Government Communication Service (2015) OASIS campaigns Guide https://gcs.civilservice.gov.uk/wp-content/ uploads/2015/09/OASIS-CampaignsGuide-.pdf

\section{BIBLIOGRAPHY}

AMEC, (International Association for the Measurement and Evaluation of Communication). (2014). Social Media Measurement Framework User Guide. Retrieved from http:// www.social-media-measurement-framework. org/wp-content/uploads/2014/06/Social-MediaMeasurement-Framework.pdf

AMEC, (International Association for the Measurement and Evaluation of Communication). (2015). Barcelona Principles 2.0. Retrieved from http://amecorg.com/wp-content/ uploads/2015/09/Barcelona-Principles-2.0development-and-detailed-changes.-7September-2015.pdf
Cutlip. M, Center, A. \& Broom, G. (1985). Effective Public Relations, (6th edn.). Englewood Cliffs, NJ: Prentice Hall.

Fairchild, M. (1997). How to get Real value from public relations. London, UK: ICO.

GCS (Government Communication Service). (2016). GCS evaluation framework. London, UK: Cabinet Office. Retrieved from https://gcs. civilservice.gov.uk/wp-content/uploads/2015/11/ GCS_GCS-Evaluation-framework_A4-_191115.pdf

Gregory, A. (2015). Planning and managing public relations campaigns. London: Kogan Page

Gregory, A. (2017). The Fundamentals of Measurement and Evaluation of Communication, in Handbook of Public Sector Communication (eds. V. Luoma-aho \& M-J Canel). London: Wiley-Blackwell. In press.

Grunig, J.E. and Hunt, T. (1984). Managing Public Relations. New York: Holt, Rinehart and Winston.

Henningsen, A., Traverse Healy, K., Gregory, A., Johannsen, A., Allison, R., Bozeat, N., \& Domaradzki, L. (2014). Measuring the European Commission's communication: Technical and methodological report. Retrieved from http:// ec.europa.eu/dgs/communication/about/ evaluation/index_en.htm

IPR (Institute for Public Relations). (1997). Guidelines for measuring the effectiveness of PR programmes and activities. The Institute for Public Relations Commission on PR Measurement and Evaluation. Gainsville, FI., 
University of Florida.

IPR (Institute for Public Relations). (2003). Guidelines for measuring the effectiveness of $P R$ programmes and activities. The Institute for Public Relations Commission on PR Measurement and Evaluation. Gainsville, FI., University of Florida.

Likely, F., \& Watson, T. (2013). Measuring the edifice: Public relations measurement and evaluation practice over the course of 40 years. In K. Sriramesh, A. Zerfass, \& J. Kim, (Eds.), Public relations and communication management: Current trends and emerging topics (pp. 143-162). New York, NY: Routledge.

Lindenmann, W. (1993). An 'Effectiveness Yardstick' to measure public relations success. PR Quarterly, 1(38), 7-9.

Macey, W., \& Schneider, B. (2008). The meaning of employee engagement. Industrial and Organizational Psychology, 1(1), 3-30.

Macnamara, J. (2002). Research and evaluation. In C. Tymson \& P. Lazar, The new Australian and New Zealand public relations manual (21st Century ed.). Sydney, NSW: Tymson Communications. pp. 100-134.

Macnamara, J. (2014). Emerging international standards for measurement and evaluation of public relations: A critical analysis. Public Relations Inquiry. 3(1), 7-29

Macnamara, J. (2017). Public sector Communication management and evaluation, in Handbook of Public Sector Communication (eds.
V. Luoma-aho \& M-J Canel). London: Wiley-Blackwell. In press.

Nesterak, E. (2014, July 13). Head of White House 'nudge unit' Maya Shankar speaks about newly formed social and behavioural sciences team. ThePsychReport. Retrieved from http:// thepsychreport.com/current-events/head-ofwhite-house-nudge-unit-maya-shankar-speaksabout-newly-formed-us-social-and-behavioralsciences-team

Noble, P. (2014). Public relations programme research and evaluation. In Exploring Public Relations (3rd ed.). R. Tench and L. Yeomans (Eds.). London: Pearson pp. $168-317$

Stacks, D., \& Bowen, S. (Eds.) (2013). Dictionary of public relations measurement and research. Gainesville FL: Institute for Public Relations. Retrieved from http://www.instituteforpr.org/ topics/dictionary-of-public-relations-measurement-and-research

Thaler, R., \& Sunstein, C. (2008). Nudge: Improving decisions about health, wealth, and happiness. New Haven, CT: Yale University Press.

Van Ruler, B. (2015). Agile public relations planning: The Reflective Communication Scrum. Public Relations Review. 41 (2), 187-194

Watson, T., \& Noble, P. (2014). Evaluating public relations: $A$ best practice guide to public relations planning, research and evaluation (3rd ed.). London, UK: Kogan Page.

Windahl, S. \& B. Signitzer (with J.E. Olson) (2009). Using Communication Theory. London: Sage. 


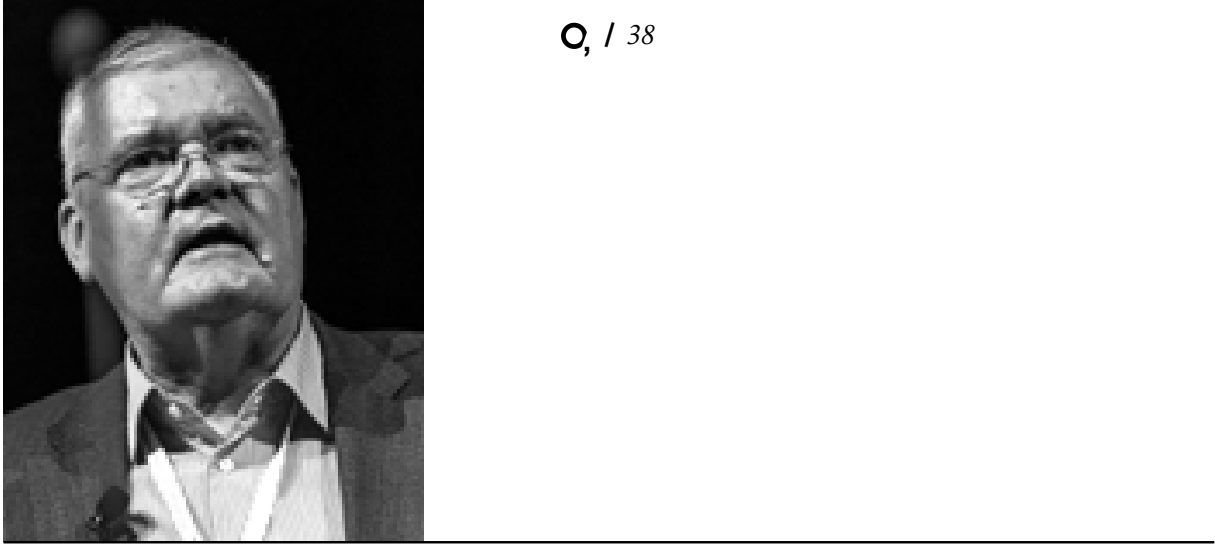

WHO?

Jim Macnamara

- Jim Macnamara PhD, FAMEC, FAMI, CPM, FPRIA is Professor of Public Communication at the University of Technology Sydney, a role he took up in 2007 following a distinguished 30-year professional career spanning journalism, public relations, and media research. Jim is the author of 16 academic and professional books and more than 200 academic and professional journal articles.

He is Chair of the Academic Advisory Group to the International Association for Measurement and Evaluation (AMEC) and a Fellow of AMEC and has advised a number of organisation on evaluation including the UK Government and the state government of New South Wales in Australia.

BEST PRACTICE MEASUREMENT IS ABOUT LISTENING, LEARNING, AND ADAPTING NOT JUST CHANGING OTHERS

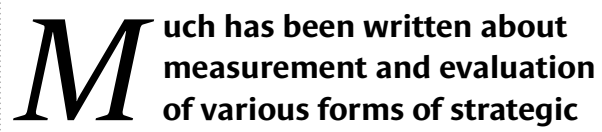
communication including public relations. Despite the plethora of articles, manuals, guides, tools, and impassioned pleas from academics and industry leaders, measurement and evaluation remain under-used and largely focussed on measuring outputs rather than outcomes and impact (Gregory \& Watson, 2008; Macnamara, 2015; Michaelson \& Stacks, 2011).

Furthermore, most proposed models for measurement and evaluation narrowly focus on outcomes that achieve the goals and objectives of the organisation undertaking the communication. 
The impact on stakeholders and audiences is seldom considered other than in terms of how they reflect the desires and intentions of the organisation. This organisation-centric approach persists despite conceptualisation of PR and corporate communication as two-way, dialogic, and focussed on relationships.

Rather than repeat advice that is provided elsewhere, this short analysis seeks to advance discussion by introducing two approaches that generate greatly increased data for planning and evaluation as well as improved results of communication.

\section{Lack of listening}

Public relations and strategic communication management including corporate communication and government communication are theorised as two-way communication, dialogue, and focussed on engagement and relationships (J. Grunig, L. Grunig \& Dozier, 2006; Johnston, 2014; Taylor \& Kent, 2014).

However, in early 2016 I released the findings of a two-year, three-country study that showed that organisations listen "sporadically at best, poorly, and sometimes not at all" to their stakeholders and publics (Macnamara, 2016a, p. 236). The Organisational Listening Project (Macnamara, 2016a, 2016b), which is continuing to explore and test various organisational listening strategies, concluded that, under the auspices of 'communication', organisations predominantly implement an 'architecture of speaking' through advertising, PR, Web sites, events, social media, and other activities focussed on disseminating their messages. From 80 to 95 per cent of the communication resources of organisations were found to be devoted to disseminating organisations' messages (i.e., speaking).

\section{Creating an architecture of listening}

The study called for government, corporate, and non-government organisations to counter-balance this by creating an architecture of listening in order to achieve their stated goals of two-way communication, dialogue, engagement, and relationships. Organisational listening requires more than adding a 'listening tool' or doing an occasional survey. My research proposed that the characteristics of an architecture of listening are:

1. A culture of listening;

2. Policies for listening;

3. Overcoming the politics of listening (e.g., the marginalisation of some groups);

4. Structures for listening;

5. Resources for listening (including human resources);

6. Skills for listening;

7. Technologies for listening;

8. Articulation of what is heard to organisation decision making and policy making (Macnamara, 2016a, 2016b).

The Organisational Listening Project may appear to be unrelated to measurement and evaluation of public communi- 
cation. However, the two practices listening and measurement undertaken for evaluation - are closely interconnected.

This is because all research involves and requires listening. Whether the method used for measurement and evaluation is surveys, focus groups, in-depth interviews, content analysis of media reporting and commentary, ethnography, experiments, random controlled trials, or statistical analysis of database records, measurement and evaluation implicitly if not explicitly have listening at their core. Measurement and evaluation involve not only the collection of data, but the processing, analysis, and interpretation of quantitative and qualitative data to try to understand audience awareness, attitudes, perceptions, concerns, interests, media preferences, intentions, and behaviour and changes in those variables.

\section{Overcoming organisational centricity}

However, the organisation-centric approach of many organisations and many practices in strategic communication mean that the listening undertaken as part of traditional research methods is often functional and instrumental. That is to say, organisations listen to what they want to listen to when they want to listen. Usually this is confined to help them target potential consumers and to measure the effectiveness of their own information and persuasion initiatives, rather than open listening to stakeholders and audiences.

The Organisational Listening Project sought to not only explore the level and effectiveness of listening by organisations but also to identify methods to improve listening to their stakeholders and publics, which often requires large-scale listening and listening across diverse interests. Attention to organisational listening is necessary because listening is much more than tokenistic attention and dialogue is not simply turn-taking at speaking. From psychology, political science, and communication literature, listening is defined as (1) recognising others who have relevant views or interests (not only 'publics' decided by the organization); (2) giving acknowledgement when others speak; (3) paying attention to what others say; (4) interpreting what they say to (5) gain understanding of their views and needs; (6) giving consideration to what they say; and (7) responding in some appropriate way, which is not necessarily agreement (Bickford, 1996; Husband, 1996, 2000, 2009; Honneth 2007; Lundsteen, 1979; Purdy \& Borisoff, 1997).

\section{Traditional methods for organisational listening}

Traditional organisational listening methods include research, increasingly referred to as insights, involving quantitative methods such as surveys and qualitative methods such as focus groups and in-depth interviews, as well as public consultation, and social media monitoring. As well as identifying that these traditional methods can be significantly improved, The Organisational Listening Project identified a number of specialist methods for tuning in to audiences, gaining insights, and creating measurable outcomes. 


\section{A new approach - Sense Making Methodology}

One of the advanced methods identified is sense making methodology (SMM). While sometimes narrowly understood as a method of making sense of data (i.e., analysis and interpretation), SMM is in fact a broad methodology for research, planning, and implementation that is focussed on creating genuine open dialogue between organisations and their publics in which the organisation listens actively in a spirit of mutuality and reciprocity. In short, it is a systematic approach for the design of dialogue beyond tokenistic efforts that often characterise government and corporate engagement. Leading advocate of this approach, Brenda Dervin, and her main co-author summarise the SMM approach as:

You listen to me, and I will listen to you; you learn from me, and I will learn from you; you trust my narratives about my material circumstances, and I may listen to the narratives within which you wrap your expertise. But you will also have to listen to my expertise.

(Dervin \& Foreman-Wernet, 2013, p. 159)

This points to one of the key principles that makes SSM fundamentally different to other top-down and expert led approaches to research and planning. SMM is based on an understanding and acceptance that "both organisations and constituencies have expertise to share, common struggles to ponder, and capacities to teach and learn from each other" (Dervin \& Foreman-Wernet, 2013, p. 160) and, therefore, SMM "mandates refocussing communication attention on dialogue rather than transmission" of information (Dervin \& Foreman-Wernet, 2013, p. 154). Dervin and her co-author state frankly: "in SMM public communication is defined as the means to not merely change constituencies but to change organisations" (p. 160).

As part of this, SMM goes further than facilitating dialogue with major stakeholders. As The Organisational Listening Project found, dialogue and consultation are often restricted to the "usual suspects" - major organisations such as business groups, trade unions, and mobilised lobby groups that represent economic and political elites (Macnamara, 2016, p. 180). SMM requires open listening and engagement of all parties potentially affected by an organisation, which often requires outreach rather than passive engagement such as waiting for submissions to consultations or relying on occasional surveys.

A further fundamental difference in the Sense Making Methodology approach is that it recognises that people who comprise audiences and publics move and change through time and space. Traditional approaches to mass communication and public communication tend to assume or "imagine" audiences as static groups identifiable by stable demographic and psychographic data (Anderson, 1991). SMM recognises that people are in a constant state of growth and change. Therefore, traditional audience segmentation works only for identifying habitual behaviours. SMM tries to understand the 
person in situation - in other words, the person at a particular point in time within the social, cultural, political, economic context in which they exist. Traditional market research that relies on quantitative statistics such as demographics uses blunt instruments to measure audience attitudes, perceptions, interests, and needs. SMM incorporates greater use of qualitative research to gain deep insights into audiences. This is important because other key principles of SMM are:

- Ultimately the intended audience controls all the gates, as sense making and meaning making of the strategic communication or organisations happens in the minds of audiences. Therefore, in communication everything begins and ends with the audience - not the organisation or channels;

- The everyday experiences of people are valid and valuable sources of information that are often dismissed in favour of 'expert' views and external scientific data. Ultimately, audiences know more about their lives than anyone else. So listen to them - often and intently. Dervin and Foreman-Wernet point out that in SMM informants in research are "theorists of their own worlds" (2013, p. 158);

- People (audiences) most trust and rely on their families, friends, and peers, so mass media campaigns will always have limited impact. SMM approaches favour agility, flexibility, multiple channels, participation, and collaboration including community-based engagement.

SMM approaches require well-meaning experts in marketing, research, and communication to "humble" their knowledge and subjugate their views and categorisations in favour of allowing audiences to speak on their own terms in their own contexts (Dervin \& Foreman-Wernet, 2013, p. 160). SMM also is cautious towards consensus, recognising that consensus is often not possible and strategies therefore have to deal with diversity and difference.

A final explanation and warning comes from Dervin and Foreman-Wernet who say: "Communication is ultimately a quid pro quo. People are willing to listen to that which collides with or is new to their worlds when those communicating at them change to communicating with them" (2013, p. 153) [italics added].

Approaches such as Sense Making Methodology are rarely used in public relations and corporate communication, but offer much to create a listening organisation, a learning organisation, and an adaptive organisation. The organisation that does not listen, learn, and adapt inevitably faces fractious issues, crises, and potentially an uncertain future. Conversely, open listening informs strategy (formative research) and provides a constant stream of feedback (evaluation), and can build productive relationships and trust. 


\section{O, I 43}

\section{REFERENCES}

Anderson, B. (1991). Imagined communities: Reflections on the origin and spread of nationalism (Rev. Ed.). New York, NY and London, UK: Verso. (Original work published 1983)

Bickford, S. (1996). The dissonance of democracy: Listening, conflict and citizenship. Ithaca, NY and London: Cornell University Press.

Dervin, B., \& Foreman-Wernet, L. (2013). Sense-making methodology as an approach to understanding and designing for campaign audiences. In R. Rice \& C. Atkin (Eds.), Public communication campaigns (4th ed., pp. 147-162). Thousand Oaks, CA: Sage.

Gregory, A., \& Watson, T. (2008). Defining the gap between research and practice in public relations programme evaluation: Towards a new research agenda. Journal of Marketing Communications, 24(5) 337-350.

Grunig, J., Grunig, L., \& Dozier, D. (2006). The excellence theory. In C. Botan \& V. Hazelton (Eds.), Public relations theory II (pp. 21-62). Mahwah, NJ: Lawrence Erlbaum.

Honneth, A. (2007). Disrespect. Cambridge, UK: Polity Press.

Husband, C. (1996). The right to be understood: Conceiving the multi-ethnic public sphere. Innovation: The European Journal of Social Sciences, 9(2), 205-215.

Husband, C. (2000). Media and the public sphere in multi-ethnic societies. In S. Cottle (Ed.), Ethnic minorities and the media (pp. 199-214).
Buckingham, UK: Open University Press.

Husband, C. (2009). Commentary: Between listening and understanding. Continuum: Journal of Media \& Cultural Studies, 23(4), 441-443.

Johnston, K. (2014). Public relations and engagement: Theoretical imperatives of a multidimensional concept. Journal of Public Relations Research, 26(5), 381-383.

Lundsteen, S. (1979). Listening: Its impact on language and the other language arts. Urbana, IL: ERIC Clearing House on Reading and Communication Skills.

Macnamara, J. (2015). Overcoming the measurement and evaluation deadlock: A new approach and model. Journal of Communication Management, 19(4), 371-387.

Macnamara, J. (2016a). Organizational listening: The missing essential in public communication. New York, NY: Peter Lang.

Macnamara J. (2016b). The work and 'architecture of listening': Addressing gaps in organization-public communication. International Journal of Strategic Communication, 10(2), 133-148.

Michaelson, D., \& Stacks, D. (2011). Standardization in public relations measurement and evaluation. Public Relations Journal, 5(2), 1-22.

Purdy, M., \& Borisoff, D. (1997). Listening in everyday life: A personal and professional approach (2nd ed.). Lanham, MA: University of America Press. 
Taylor, M., \& Kent, M. (2014). Dialogic engagement: Clarifying foundational concepts.

Journal of Public Relations Research, 26(5), 384-398. 


\section{$30^{\circ}$}

Viratinnin ammattiaive:

\section{PROCOMPRO \\ -VALMENNUSKOKONAISUUDET SYVENTÄVÄT ASIANTUNTIJAN OSAAMISTA}

Kolme kokonaisuutta, joiden ohjelmistosta valitset itsellesi sopivan taitoalueen.

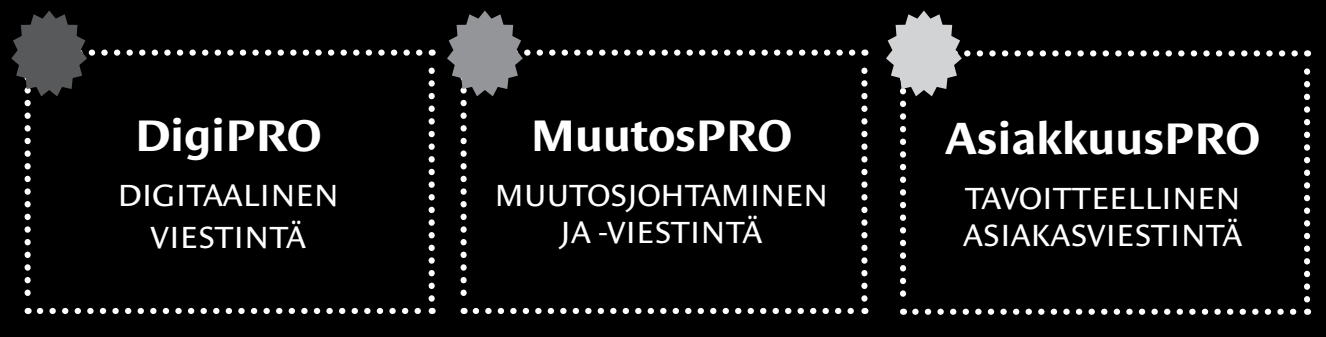

Valitse omat suosikkisi digiviestinnän koulutussisällöistä. Mukana mm. web-analytiikka ja hakukoneoptimointi sekä sosiaalisen median strategia ja mittaaminen.

\section{MuutosPro}

MUUTOSJOHTAMINEN JA -VIESTINTÄ

\section{AsiakkuusPRO}

TAVOITTEELLINEN ASIAKASVIESTINTÄ
Menestys alkaa asiakkaista. Kokonaisuudessa mukana mm. yrityksen brändi-identiteetti, sisäiset asiakassuhteet sekä asiakaskokemuksen kehittäminen ja johtaminen.

Valmennuskokonaisuuden suorittamisesta saat ProComPRO-todistuksen!

Viidestä koulutuspäivästä koostuvan kokonaisuuden hinta ProComin jäsenille 2100 euroa + alv $24 \%$, ei-jäsenille 2900 euroa + alv $24 \%$.

Uusia tietoja ja taitoja muutoksen johtamiseen eri tasoilla. Mukana mm. muutosprojektin johtaminen, muutokseen motivointi sekä muutos ja media. 


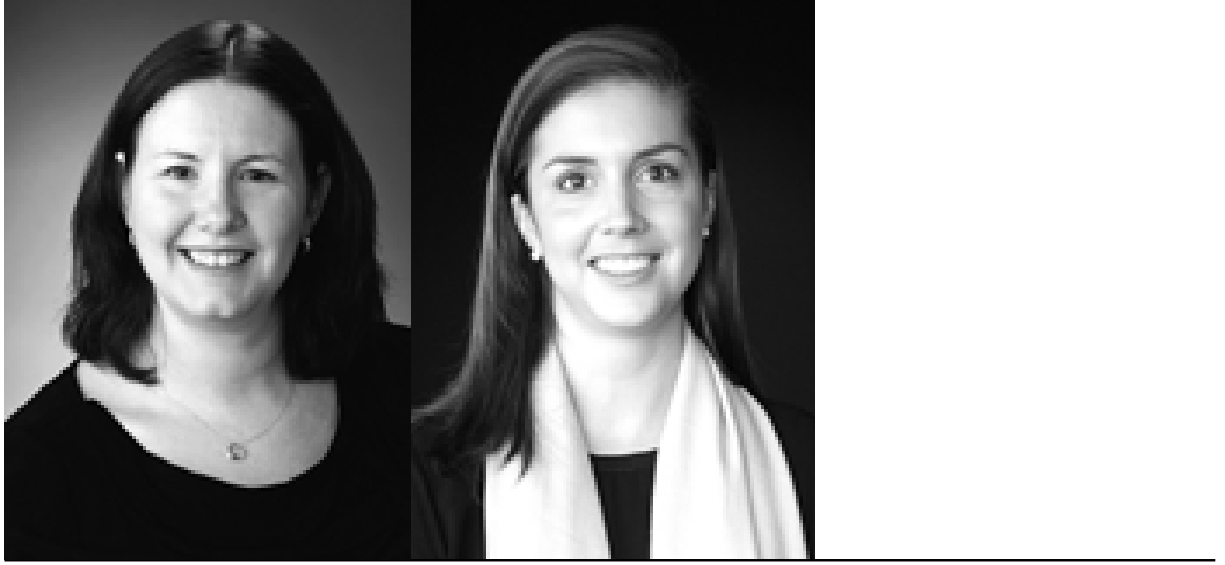

WHO?

\section{Jodie Conduit and Rebecca Dolan}

- Jodie Conduit is an Associate Professor in Marketing, after being awarded her PhD from Monash University in 2000. Her academic interests lie in understanding how to engage consumers in interactions with organisations, and each other, that enable them to work together to achieve meaningful and relevant outcomes. This underpins her research agenda in the areas of customer engagement, value (co-)creation, organisational capabilities, services marketing and marketing strategy. Her research has been widely published in leading journals including the Journal of Service Research, Journal of Business Research, Journal of Business Ethics, and the Journal of Marketing Management among others.

Rebecca Dolan is a lecturer in Marketing at the University of Auckland in New Zealand. She was awarded her PhD from The University of Adelaide in 2015. Rebecca's research focusses on contemporary issues in marketing such as digital disruption, social media, and customer engagement. She has a particular interest in deriving insights from Big Data, particularly investigating patterns of online consumer behaviour through digital and social analytics. Rebecca's research has been published in the Journal of Strategic Marketing and The International Journal of Wine Business Research, among others. 
SOCIAL MEDIA ANALYTICS:

MEASUREMENT TOOLS

FOR EXPLORING ONLINE ENGAGEMENT

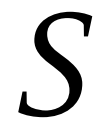

ocial media enables hundreds of millions of new and existing customers to share opinions, thoughts and feelings online, providing a trail of conversations to explore and understand. Data generated through these social media interactions enables communication and marketing professionals' immediate access to the text, images and videos that consumers engage with through social media.

This chapter explores six types of social media engagement behaviours, which can be identified and measured through online social media data collection tools. Specifically, two software programs designed to extract communication data from Facebook; Facebook Insights and NCapture are discussed. We demonstrate how they are valuable tools to enhance our understanding of online communication between brands and consumers.

\section{Introduction}

In 2016, there were more than 1.65 billion monthly active users on Facebook, 1 billion monthly active users of WhatsApp, 500 million monthly active users of Instagram, and 310 million monthly active users of Twitter (Statista, 2016). The interactive properties of social media have transformed consumers from passive observers of content to active participants, who create vast quantities of user generated content through their conversations, interactions and behaviours online. As a result, new immediate data have emerged as valuable resources to measure the interaction and behaviours of customers online.

The rise of social media sites has created new platforms with a trail of data detailing customer interactions and conversations for businesses to explore and understand. Access to this data has disrupted traditional approaches to customer relationship management, causing a need for organisations to consider how to build insights from the large quantities of data made available by social media (Manovich, 2011). Through understanding data derived from social media platforms, managers can potentially know radically more about their customers and directly translate that knowledge into improved decision making and performance (McAfee, Brynjolfsson, Davenport, Patil, \& Barton, 2012). The major challenge for communication and marketing practitioners lies within the ability to understand and extract insights from social media data in order to better understand customers 
(Bijmolt et al., 2010).

\section{How customers engage on social media}

Traditional categorisations of 'users' of social media distinguish between users who are more active, and create content, compared to those who are members of a community but do not post, referred to as 'lurkers' (Preece et al., 2004). This basic categorisation of online users is limited in its general nature and fails to take into account the diverse number of possible actions available to fans in dynamic online platforms.

Customer engagement behaviours within social media can also be explored in terms of their intensity. Muntinga et al. (2011) propose three social usage types: consuming (low level of brand related activity), contributing (medium level) and creating (highest level). Lower levels of engagement have been described as situations in which customers consume content or using very basic forms of feedback, such as 'liking' a page on Facebook. Comparatively, higher engagement occurs in cases when customers more actively process the role of the brand in their lives, participating in forms of co-creation through writing reviews, comments or creating content (Malthouse et al., 2013). Further, consumers may exhibit a level of whereby they do not actively contribute to the brand's social media platform.

This chapter provides an insight into the way in which online engagement behaviours can be measured and interpreted.

\section{How can engagement behaviour be measured?}

In this section, we describe 6 specific types of social media behaviours that can be measured to indicate the extent of engagement that the customer has with your brand in Facebook. Within these six types, it is also important to recognise that behaviours can be positive and negative in nature, and also vary in intensity. Luomaaho (2015) refers to positively engaged stakeholders as 'Faith-holders', who trust and like the organization or brand and support it via their beliefs, emotions and behaviours. In this chapter, we focus on the behaviours of positively engaged consumers, through creating, contributing and consuming behavior. Stakeholders may also be negatively engaged 'hateholders' (Luoma-aho, 2015) who dislike or hate the brand or the organization and harm it via their behaviours. We explore this concept through the description of detaching and destructive social media engagement behaviour.

The behaviours are depicted in Figure 1 next page. 


\section{Figure 1:}

Social media engagement behaviours

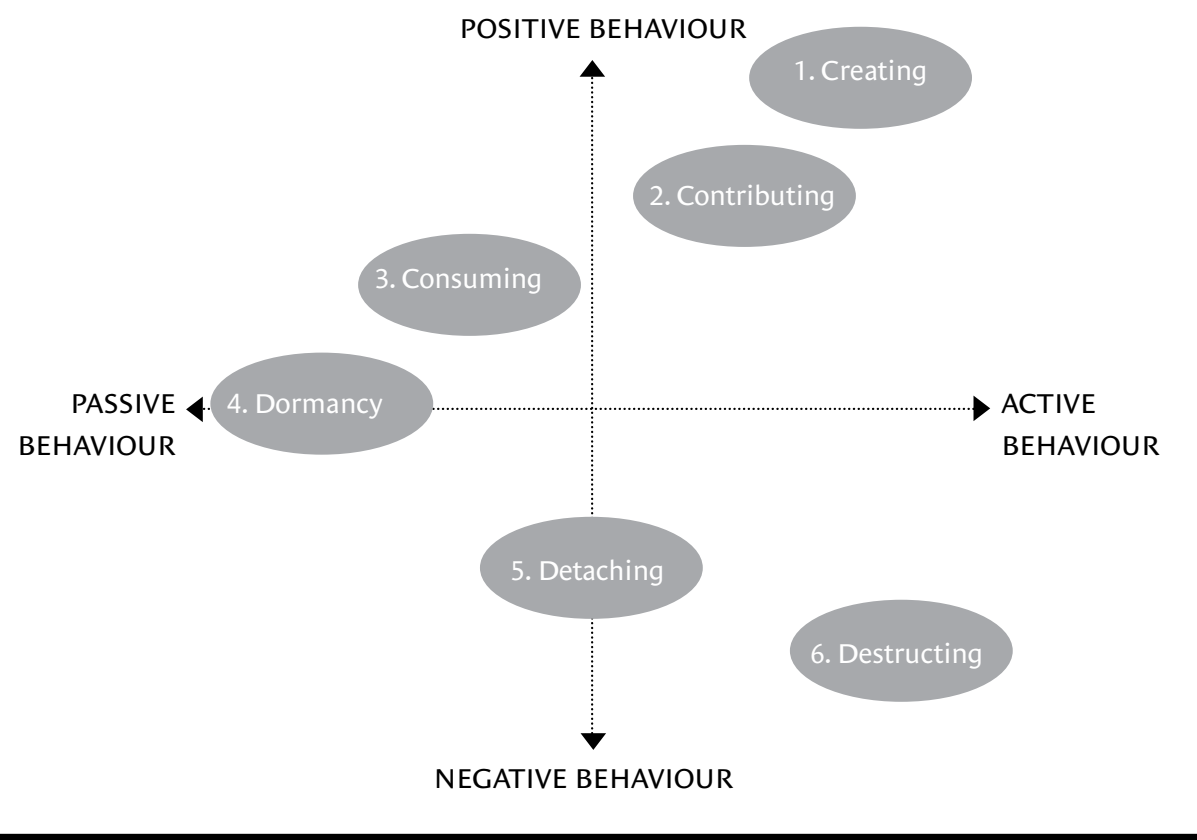

1. Customers who create new content Description: Creating behaviour re presents the highest level of positive engagement. Creators act as co-developers of the content on social media pages, through the initiation of positive, active content contributions, and subsequent interaction with the brand, and other members.

Measurement: Managers can investigate the number of positive comments that are created by fans. 


\section{0,150}

\section{Figure 2:}

Creating engagement behaviour

- Air New Zealand

3. A April 7 at $9: 34 \mathrm{pm}$ -

Thank you air $\mathrm{nz}$ staff at Auckland airport and palmerston north for the assistance in helping me board and get off the plane. (flight number 5113)

Big thumbs up for the flight attendances who made sure I was ok during the flight, and the wonderful lady who went and checked my luggage in.

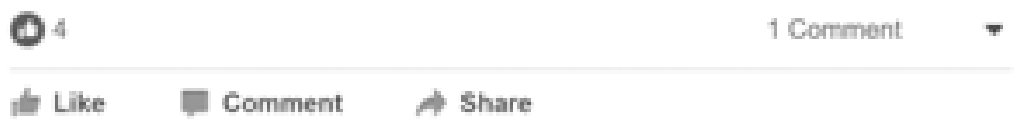

\section{Customers who contribute to existing content}

Description: Social media users engage in this contributing behaviour through making positive, active contributions to existing content on the social media brand page. Customers contribute through forwarding content, for example through the 'Share' function on Facebook or 're-tweet' function on Twitter. Through this form of contribution, customers become distributers of pre-existing content.

Measurement: Contributing measures include the total number of likes received by the page post, and the total number of shares received by the page post.

\section{Customers who consume existing content}

Description: This type of engagement behaviour refers to the passive consumption of brand-related content. This consumption is achieved through reading reviews, discussions and comments, in addition to viewing photos, watching videos and clicking on content and links.

Measurement: Indicators of consuming behaviour include the number of clicks to play (video), link clicks, clicks on the page content, and photo views/clicks.

\section{Customers who are dormant}

Description: Social media users exhibiting a state of dormancy are often referred to as 'lurkers', and are defined by making zero active or passive contributions to the social media brand post. 
They do not engage with social media through the consumption, contribution to or creation of any content Measurement: Dormancy can be measured by exploring post reach and active engagement. Post reach is the number of people who have seen the post in their news feed. The number of people who have seen the post, minus the number of people who have engaged (clicked, liked, commented, shared), equals the number of dormant fans.

\section{Customers who detach}

Detachment represents a low level of negative engagement. Detached customers privately remove themselves from the social media page through selecting to hide all future content, or 'unlike' or 'unsubscribe' from the page. This reflects a termination of the inter action, meaning there is a temporary or permanent conclusion to the consumers' behavioural engagement with the social media page.

Measurement: Detachment can be explored by considering the negative feedback clicks, separated into four metrics; 'hide post', 'hide all posts', 'report as spam' and 'unlike page'.

\section{Customers who create destructive content}

Description: Destructive engagement behaviour occurs when social media users actively create negative content on social media brand pages, interacting with the brand, other customers and the public. For example, the comment shown in Figure 3 from the Jetstar Airline Facebook Page demonstrates destructive engagement. Measurement: in order to explore destructive content, user comments should be explored and comments with negative sentiment can be described as destructive.

\section{Figure 3:}

Destructive engagement behaviour

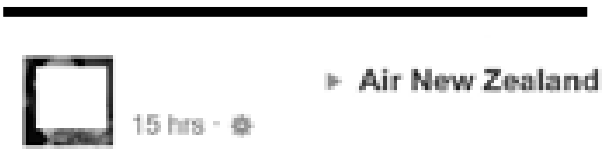

So disappointed Air New Zealand. We can understand that sometimes fights are cancelled for reasons out of your control but seriously your communication or lack there of is disgusting. We have been waiting for hours to find out our options and we're still waiting 


\section{Tools to access engagement behaviour data:}

There are two tools that can be used to collect customer data from Facebook; 'Facebook Insights' and 'NCapture'. These tools can be utilised to provide a detailed understanding of the six engagement behaviours listed above.

\section{Facebook Insights:}

Facebook Insights is a tool provided to administrators of Facebook brand pages to enable high-level monitoring of the activities that occur on that page. It allows administrators to download data regarding the performance of a post, including the number of people the post reached, the number of people who clicked the post, and the number of people who liked, commented on or shared the post. If the post is a video, insights data also shows the total number of video views, and length of video views.

Despite these capabilities, there are some limitations to the use of Facebook Insights data. Firstly, it is provided exclusively to administrators of the Facebook page, and therefore analysis of multiple brands data, or competitor data is not possible. Secondly, whilst Facebook Insights collects the 'number of comments' as a metric of engagement, the content of these comments is not captured. Finally, as the features of Facebook Insights are controlled by Facebook a change in policy could mean that a metric considered valuable may become no longer available, or a change in measurement structure. Many of these shortcomings of the Facebook
Insights tool can be overcome through the simultaneous use of the program 'NCapture'.

\section{NCapture}

NCapture is a web browser extension that allows fast collection of content from web pages, online PDF's, Facebook, and Twitter. NCapture allows the downloading of Facebook wall posts and comments from any URL, meaning that permissions is not required to access this data (unlike Facebook Insights). NCapture collects similar data to Facebook Insights, including the content, type and timing of brand page posts, number of likes and number of comments.

NCapture has an advantage over Facebook Insights in its ability to collect the content and authorship of fan comments, relevant to each post. Depending on the individual user's privacy settings, NCapture also collects demographic data such as gender, age and location for the users who interact with a post. Data missing from the NCapture extension includes the number of shares made on a post, post reach, the number of clicks, video views and amount of negative feedback received by the post, all functions which are available through Facebook Insights.

\section{How can engagement behaviour information be used?}

The measurement of online engagement behaviours in a social media setting will provide clarity to managers who wish to understand the ways in which customers engage with their brands. By using a comprehensive approach to analy- 
sing engagement behaviour, there is an opportunity for managers to explore the relationship between specific engagement behaviours and purchasing patterns. For example, a manager may wish to explore whether consumers who contribute to content are more likely to purchase, compared to those users who remain dormant. Further, as suggested by Luoma-aho (2015) communication and marketing managers should not ignore negatively engaged 'hateholders', who engage online through detaching and destructing behaviour. Rather, they can be seen as a potential for future positively engaged consumers, if their issues are addressed.

Upon establishing which behaviours are most valuable, managers should also consider the strategies used to facilitate certain engagement behaviours. This could include consideration of the type of content posted within social media, and how it related to each of the 6 behaviours proposed. This would provide communication and marketing managers with a clearer understanding of the return on investment of the social media strategy. An evaluation of the dollar investment of increasing a customer's engagement from dormant to actively engage could be translated into sales propensity.

\section{To conclude}

This chapter provided an overview of the importance of understanding and measuring online engagement within online social platforms. Social media analytics tools such as Facebook Insights and NCapture were introduced as tools for social media engagement analytics.

Using social media data in addition to appropriate social media analytics will enable marketers to develop their understanding of how positive engagement behaviours are facilitated, or how negatively engagement behaviours may be mitigated, based on the strategic design of content within social media.

\section{Free available online sources to start with:}

http://sproutsocial.com/insights/what-is-social-media-engagement/

https://blog.bufferapp.com/measure-social-media-engagement

\section{REFERENCES:}

Baird, C. \& Parasnis, G. (2011). "From social media to social customer relationship management". Strategy \& Leadership, 39, 30-37.

Cvijikj, I. P. \& Michahelles, F. (2013). "Online engagement factors on Facebook brand pages". Social Network Analysis and Mining, 3, 843-861.

De Vries, L., Gensler, S. \& Leeflang, P. S. (2012). "Popularity of brand posts on brand fan pages: An investigation of the effects of social media marketing". Journal of Interactive Marketing, 26, 83-91.

Hollebeek, L. D., Glynn, M. S. \& Brodie, R. J. (2014). "Consumer brand engagement in social 


\section{O, I 54}

media: Conceptualization, scale development and validation". Journal of interactive marketing, 28, 149-165.

Luoma-aho, V. (2015). "Understanding Stakeholder Engagement: Faith-holders, Hateholders \& Fakeholders." Research Journal of the Insitute for Public Relations, 2 (1). Retrieved from http:// www.instituteforpr.org/understanding-stakeholder-engagement-faith-holders-hateholders-fakeholders/

Malthouse, E. C., Haenlein, M., Skiera, B., Wege, E. \& Zhang, M. (2013). "Managing customer relationships in the social media era: Introducing the social CRM house". Journal of Interactive Marketing, 27, 270-280.

Muntinga, D. G., Moorman, M. \& Smit, E. G. (2011). "Introducing COBRAs". International Journal of Advertising, 30, 13-46.

Nair, M. (2011). "Understanding and measuring the value of social media". Journal of Corporate Accounting \& Finance, 22, 45-51.

Preece, J., Nonnecke, B. \& Andrews, D. (2004). "The top five reasons for lurking: improving community experiences for everyone". Computers in human behavior, 20, 201-223.

Statista. (2016). "Statistics and Market Data on Social Media \& User-Generated Contetn" [Online]. Available at: https://www.statista.com/ markets/424/topic/540/social-media-user-generated-content/ [Accessed 13 June 2016].
Wallace, E., Buil, I., De Chernatony, L. \& Hogan, M. (2014). "Who Likes You and Why? A typology of Facebook Fans". Journal Of Advertising Research. 


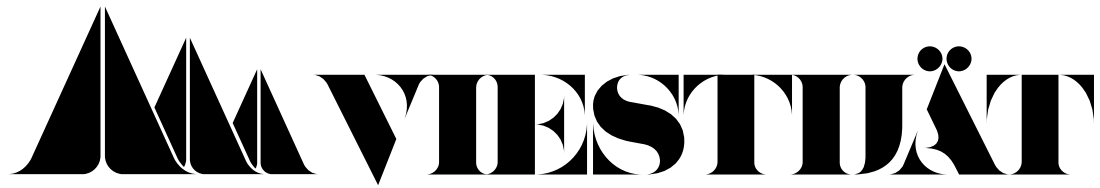

WWw.viestijat.fi 
hyödyt saada mitattavaan muotoon. Tämä helpottaisi myös viestinnän ammattilaisten työtä. Heidän tehtäväkseen jää usein perustella, miksi sisäisen vuorovaikutuksen kehittämiseen pitäisi investoida ja mikä sisäisen viestinnän välineistä saatava hyöty yritykselle on. Tässä artikkelissa esittelen erilaisia ratkaisuja ja näkökulmia siihen, miten organisaation sisäisestä sosiaalisesta mediasta saatavaa dataa analysoimalla viestinnän ammattilaiset voisivat tuoda organisaation sisällä käytävän verkkokeskustelun mitattavaan muotoon. Lisäksi esittelen tutkimuksia siitä, miten sosiaalisen median analysointia on organisaatioissa hyödynnetty ja millaisia tuloksia organisaatioiden sisäistä digitaalista viestintää analysoimalla voidaan koko organisaatiosta saada.

\section{Johdanto: miksi mitata}

\section{sosiaalisen median sisältöjä?}

Digitaalisten sisältöjen ja niiden analytiikan hyödyntämistä tuodaan yhä vahvemmaksi osaksi organisaatioiden johtamista. Laskentatoimen järjestelmistä saatavaa dataa käytetään kustannusten optimoimiseen, ja myynnin järjestelmistä kerättävää tietoa analysoidaan esimerkiksi mainonnan kohdentamisen tueksi. Lisäksi data-analytiikan tukena käytetään erilaisia henkilöstölle ja sidosryhmille suunnattuja kyselyitä.

Organisaation sisäisen viestinnän ja vuorovaikutuksen analysoinnissa on kuitenkin turvauduttu perinteisesti lähinnä erilaisiin kyselyihin, joissa käytettävät mittarit voidaan karkeasti jakaa kolmeen luokkaan: 1) viestintätyytyväisyyteen ja -ilmapiiriin liittyviin mittareihin, 2) organisaation maineeseen liittyviin mittareihin sekä 3) strategiseen viestintään liittyviin mittareihin (Juholin, 2009). Viestintätyytyväisyyteen ja -ilmapiiriin liittyvillä kyselyillä voidaan saada tietoa organisaatiossa käytetyistä viestintäkanavista, siitä, kuinka hyvin niiden kautta saadaan tietoa, ja kuinka hyväksi henkilöstö kokee mahdollisuutensa vaikuttaa niiden kautta. Tällaisten kyselyiden taustalla on perinteinen ajattelutapa viestinnästä sanomien siirtona, eikä viestintätyytyväisyttä tai -ilmapiiriä mitattaessa usein huomioida työntekijöiden omia vaikutusmahdollisuuksia ilmapiirin rakentamiseen. Maineeseen ja strategiaan liittyvissä kyselyissä sisäisen viestinnän mittarit ovat yksi osa-alue, jotka tuottavat tietoa siitä, kuinka hyvin organisaatio on onnistunut viestimään esimerkiksi innovatiivisuudestaan, visioistaan ja johtajuudestaan erilaisten sidosryhmien kanssa (Fombrun, Gardberg \& Sever, 2000). Sisäisen viestinnän näkökulmasta yksi keskeinen sidosryhmä on organisaation oma henkilöstö. Mainekyselyillä voidaankin mitata sitä, millainen maine organisaatiolla on henkilöstön keskuudessa. Strategiaan liittyvät kyselyt eroavat kahdesta edellä esitellystä kyselytyypistä erityisesti siinä, että strategiakyselyissä keskeisenä ajatuksena on vuorovaikutteisuus henkilöstön kesken. Tällaisissa kyselyissä henkilöstö nähdään aktiivisena ja itseohjautuvana toimijana, jolla on oma roolinsa strategian kehittämisessä ja toteuttamisessa. 
Kyselyt perustuvat kuitenkin itseraportointiin ja henkilöstön omiin käsityksiin viestinnän toimivuudesta ja vaikuttavuudesta. Ne myös vaativat vastaajiltaan aikaa ja tarpeeksi kattavaa vastaajajoukkoa, jotta tulokset olisivat yleistettävissä koko organisaatioon. Kyselyillä ei koskaan päästä tarkastelemaan täysin objektiivisesti esimerkiksi eri viestintäkanavien käyttömäärää tai sitä, ketkä organisaatiossa viestivät mistäkin asiasta, kenen kanssa ja milloin, koska kyselyt perustuvat vastaajien omiin käsityksiin ja arvioihin.

Itsearviointiin perustuville tutkimusmenetelmille on myös tyypillistä, että vastaajat korostavat vastauksissaan niitä puolia, joiden he ajattelevat olevan suotavia, ja vähättelevät raportoinnissaan niitä puolia, joiden he eivät ajattele olevan sosiaalisesti hyväksyttyjä. Organisaatiotutkimuksissa tämä korostuu, koska vastaajat voivat epäillä, että heidän työnantajansa saavat vastaajien henkilöllisyyden jotain kautta selville. (Donaldson \& Grant-Vallone, 2002.)

Itsearvioinnin täydennykseksi organisaatioviestinnän tutkimuksessa tarvitaankin menetelmiä, jotka voivat mitata organisaation jäsenten jokapäiväistä viestintää ja vuorovaikutusta käsityksiin, kokemuksiin ja niiden muisteluun perustuvan itseraportoinnin sijaan. Järjestelmät, joissa käyttöaktiivisuus ja sisältöjen kuluttaminen, tuottaminen ja jakaminen sekä niihin käytetty aika tallentuvat automaattisesti, tuovat uuden mahdollisuuden tällaisen tiedon saamiseen (ks. myös Rice \& Bormann, 1983). Tämän vuoksi organisaation sisäisten viestintävälineiden, kuten sisäisen sosiaalisen median ja sen sisältöjen analysoiminen voi tarjota uuden, mitattavan näkökulman organisaation sisäiseen viestintään.

Yritysten sisäisellä sosiaalisella medialla (enterprise social media, ESM) tarkoitetaan tutkimuskirjallisuudessa verkkoalustoja, joiden kautta työntekijät voivat 1) viestiä joko organisaation tiettyjen jäsenten kanssa tai lähettää viestejä, jotka kaikki organisaation jäsenet näkevät, 2) osoittaa joko implisiittisesti tai eksplisiittisesti, ketkä työntekijät kuuluvat omaan viestintäverkostoon, 3) lähettää, muokata ja valikoida itseensä tai muihin liittyviä tekstejä ja tiedostoja, sekä 4) katsella milloin tahansa muiden organisaation jäsenten viestejä, viestintäverkostoja, tekstiä ja tiedostoja, joita nämä työntekijät ovat lähettäneet, muokanneet tai valikoineet (Leonardi, Huysman \& Steinfield, 2013, 2). Tyypillisimpiä organisaatioiden käytössä olevia sisäisen sosiaalisen median alustoja ovat esimerkiksi Yammer, Google+ for work sekä Jive.

Sisäisen sosiaalisen median sanotaan eroavan muista, perinteisistä viestintävälineistä, koska sen kautta organisaatioissa käytävät keskustelut ja viestintäsuhteet tulevat näkyväksi myös niille työntekijöille, jotka eivät ole osallisina kyseisessä vuorovaikutuksessa tai edes tunne viestintäosapuolia entuudestaan. Sen sijaan, että sisäistä sosiaalista mediaa ajateltaisiin perinteisesti organisaation viestintäkanavana, jossa viestit siirtyvät, sitä tulisikin tarkastella alustana, jossa vuorovaikutus tapahtuu samalla tavalla kuin esimerkiksi toimistoissa, työpaikan käytävillä ja 
kokoushuoneissa. Se, että vuorovaikutus on sosiaalisessa mediassa digitaalista, mahdollistaa kuitenkin sen, että kuka tahansa organisaation työntekijä voi osallistua yleiseen keskusteluun tai havainnoida sitä ajasta ja paikasta riippumatta. (Leonardi, Huysman \& Steinfield, 2013.)

\section{Mitä asioita sisäisen sosiaalisen median keskusteluista voidaan mitata?}

Organisaatioiden käyttöön räätälöidyissä sisäisen sosiaalisen median sovelluksissa analytiikkaa tehdään jatkuvasti helpommin lähestyttäväksi erilaisten automaattisten visualisointien kautta. Järjestelmien käyttäjämäärät, klikkaukset sekä digitaalisten sisältöjen jakaminen ja kulutus saadaan näkyviin reaaliajassa, ja näitä lukuja voidaan hyödyntää seurattaessa viestinnän vaikuttavuutta tai tiedon leviämistä organisaatioissa ja niiden ulkopuolella. Analytiikan ja visuaalisuuden helpottumisesta huolimatta organisaatioiden sisäisen sosiaalisen median käyttöä ja etenkin niiden sisältöjä on kuitenkin tutkittu tieteellisesti vielä varsin vähän. Siinä missä ulkoisen sosiaalisen median, kuten Twitterin, sisältöjä on tutkittu esimerkiksi ohjelman tarjoaman avoimen ohjelmointirajapinnan kautta jo melko paljon, voitaisiin samantyyppistä tietoa käyttäjien viestinnästä ja sosiaalisista verkostoista hyödyntää myös organisaatioiden sisäisen sosiaalisen median analysoimiseen. Tällaista tietoa olisi jo saatavilla myös yrityksen sisäisen sosiaalisen median sisällöistä, mutta sen hyödyntämistä organisaatioiden toiminnan kehittämiseen ei ole vielä ainakaan tieteellisessä kirjallisuudessa juuri raportoitu. Esimerkiksi organisaation sisäisen sosiaalisen median sisältöjen tykkäysten määrää ja viestien vastavuoroisuutta, sisältöjen jakamista, profiilien katselukertoja tai suhdeverkostoja analysoimalla voitaisiin saada arvokasta tietoa organisaatioviestinnän kehittämiseksi.

Toisaalta data-analytiikka voi auttaa myös organisaation verkkokeskustelujen sisällön analyysissa, kun tulokset voidaan koota helposti yksilön tasolta joukkojen tasolle. Jos useampi työntekijöistä puhuu organisaation sisäisessä sosiaalisessa mediassa samasta asiasta, on asia todennäköisemmin myös koko organisaation kannalta kiinnostava (Shami et al., 2014). Tutkimukset ovat osoittaneet, että yrityksen sisäistä sosiaalista mediaa analysoimalla voidaan mitata esimerkiksi työntekijöiden vuorovaikutussuhteiden laatua ja syvyyttä (Wu, DiMicco \& Millen, 2010) sekä heidän sitoutumistaan työhönsä (employee engagement; Shami et al., 2015). Perinteisemmistä viestintäkanavista, kuten työyhteisön sähköpostiarkistoista tehty sisällönanalyysi on osoittanut, että tietyt sanat ja sanonnat paljastavat työpaikan valta- ja hierarkiasuhteita hyvinkin tarkasti (Gilbert, 2012). Tutkimukset antavat myös osviittaa erilaisten algoritmien ja kehittyvien laskennallisten sosiaalitieteiden mahdollisuuksista koko organisaation toiminnan ennustamiseen digitaalisten verkkokeskustelujen pohjalta.

\section{Millä mittareilla?}

Sisäisen sosiaalisen median sisältöjen mittaaminen ja analysoiminen voisikin tuottaa tietoa organisaation senhetkisestä 
tilasta, mutta myös paljon puhuttaneista tapahtumista lähimenneisyydessä sekä henkilöstöä innostavista ja huolettavista asioista tulevaisuudessa. Sisäisen sosiaalisen median keskusteluiden kautta voitaisiin piirtää kuvaa siitä, keitä organisaation jäsenet ovat suhteessa muihin, millaisia ryhmittymiä ja yhteisöjä organisaatiossa on yli virallisten organisaatiorajojen, ja ketkä organisaatiossa keskustelevat keskenään. Sosiaalisen median verkostoja mittaamalla voitaisiin myös saada tietoa siitä, ketkä työntekijät tai mitkä tiimit ja osastot eivät vielä tunne toisiaan tai ole tekemisissä toistensa kanssa, vaikka ehkä pitäisi, ja missä osissa organisaatiota tieto ei ehkä kulje samalla tavalla kuin toisissa. Tämä kaikki täytyy kuitenkin suhteuttaa yleiseen järjestelmän käyttöaktiivisuuteen. Jos jokin osasto tai tiimi on kokonaan näkymätön organisaation sisäisessä sosiaalisessa mediassa, täytyy syitä tälle etsiä muilla menetelmillä. Viestien vähäisyys tai sosiaalisen median profiilin päivittymättömyys voi johtua useasta syystä, kuten taitojen tai motivaation puutteesta. Pelkän sisäisestä sosiaalisesta mediasta saatavan datan mittaaminen ja visualisoiminen eivät siis aina riitä, vaan tarvetta voi olla myös muunlaiselle analysoinnille, jotta järjestelmän hyödyt ja haasteet tulevat kokonaisuudessaan nähdyiksi.

Viestinnän ammattilaisten kannattaa kiinnostua laskennallisten sosiaalitieteiden ja erilaisen data-analytiikan mahdollisuuksista organisaation sisäisen viestinnän mittaamisessa ja analysoimisessa. Jo käytössä olevat sisäisen viestinnän välineet, kuten organisaatioiden sisäinen sosiaalinen media, voivat tarjota valmiin alustan työyhteisöjen sisäisen viestinnän ja vuorovaikutuksen hyötyjen mittaamiselle ja tulevaisuudessa jopa organisaatioiden toiminnan ennustamiselle. Säännöllisen sosiaalisen median sisällönanalyysin kautta voidaan seurata organisaatiossa käytävän keskustelun tilaa, nähdä mitkä asiat huolettavat tai innostavat organisaation jäseniä, tai analysoida tiedon leviämistä ja erilaisia verkostoja sekä organisaation jäsenten tietoisuutta toisistaan ja osaamisestaan. Leonardin (2015) mukaan pelkästään sillä, että työntekijöillä on toisistaan ja verkostoistaan ns. metatietoa, eli he tietävät, kuka organisaatiossa tietää mitä ja kuka tuntee kenet, on nähty olevan positiivisia vaikutuksia työhön. Metatiedon lisääntyminen voi parantaa esimerkiksi tiimien suoriutumista, uusien innovaatioiden syntymistä ja vähentää päällekkäisten työtehtävien tekemistä organisaatioissa.

Sisäisen sosiaalisen median analytiikasta saatuja tuloksia voidaan verrata aikaisempiin tuloksiin sekä yhdistää henkilöstökyselyihin tai muihin organisaatiossa tehtäviin tutkimuksiin. Lisäksi sisäisen sosiaalisen median käyttötapoja ja sisältöä analysoimalla voidaan saada järjestelmän hankinnasta ja käyttöönotosta aiheutuneita kustannuksia hyödynnetyksi ja perustelluksi myös muulla tasolla kuin pelkästään viestinnän lisääntymisen, tehostumisen ja tiedon jakamisen helpottumisen näkökulmasta.

\section{Mitä tuloksilla tehdään?}

Organisaation sisäisen sosiaalisen median sisältöjä voidaan analysoida säännölli- 
sin väliajoin vaikkapa joka kuukausi tai puolivuosittain, tuloksia toisiinsa verraten, tai sisältöjä voidaan analysoida erikseen esimerkiksi tiettyihin prosesseihin liittyen. Joissain suurissa hajautetuissa organisaatioissa tätä jo tehdään ja sosiaalisen median työkaluista saatavaa dataa hyödynnetään muun muassa työntekijöiden asiantuntemuksen ymmärtämisessä ja levittämisessä muun organisaation tietoisuuteen. Esimerkiksi IBM:llä sosiaalisen median työkaluja hyödynnetään työntekijöiden viestintäverkostojen näkyväksi tekemisessä ja tietoisuuden lisäämisessä liittyen omaan ja muiden asiantuntemukseen. Sisäisellä sosiaalisen median analytiikalla voidaan myös parantaa innovaatioprosessien läpinäkyvyyttä. Suuressa organisaatiossa uusien työntekijöiden sosiaalistamisen ja hiljaisen tiedon levittämisen ja keräämisen nähdään olevan helpompaa sosiaalisen median keskustelujen kuin perinteisten viestintäkanavien kautta. Niiden ajatellaan myös lisäävän organisaation innovatiivisuutta tuomalla yhteen erilaisia työntekijöitä eri puolilta hajautettua, kansainvälistä organisaatiota. (Majchrzak, Cherbakov \& Ives, 2009.)

Mittaustuloksia tulkittaessa ja hyödynnettäessä täytyy kuitenkin muistaa, että suurten digitaalisten tekstimassojen ja keskusteluaineistojen analyysi vaatii aina tulkitsijan. Kielen rakenteet, ironia ja huumori ovat niin monitulkintaisia ja -tasoisia, että laskennalliset tieteet voivat tarjota mittaukselle perustan ja tehostaa ihmisen analysointikykyä, mutta eivät täysin korvata sitä (Grimmer \& Stewart, 2013). Lisäksi sosiaalisen median käyttötavat, kuten klikkaukset tai tiedon jakaminen eivät aina automaattisesti tarkoita sitä, että kyseisestä sisällöstä pidettäisiin, vaan linkkejä erilaisiin artikkeleihin voidaan jakaa eri motiivein ja monista eri syistä.

Myös eettiset kysymykset nousevat keskiöön, kun pohditaan sellaisten sisältöjen analysoimista ja mittaamista, jota niiden tuottajat, organisaation jäsenet, eivät ole luoneet mittaamista vaan aitoa keskustelua varten. Eettistä harkintaa tulisi käyttää siinä, pitäisikö työntekijöiden olla tietoisia jo järjestelmää käyttöönottaessaan, että sinne luotua sisältöä ja ihmisten välistä vuorovaikutusta voidaan analysoida ja mitata erilaisiin tarkoituksiin. Myös huoli keskustelijoiden anonymiteetin säilymisestä voi olla etenkin työyhteisön suljetuissa sisäisen sosiaalisen median keskusteluryhmissä todellinen. Työntekijät voivatkin siirtää keskustelunsa toisille foorumeille tai lakata keskustelemasta tai käyttämästä jotain järjestelmää sen takia, että sen sisältöjä voidaan analysoida ja mitata jälkeenpäin. Tällaisia asioita tulisi miettiä jo organisaation sisäistä sosiaalista mediaa käyttöönotettaessa ja sen hyödyntämistä suunniteltaessa.

\section{Lopuksi: Mittaamisen viisi viisautta}

Sisäisen sosiaalisen median mittaaminen ja analysoiminen voi tuoda organisaation sisäisiä keskustelunaiheita, ideoita ja hiljaista tietoa näkyväksi organisaation eri tasoilla, auttaa tunnistamaan organisaation viestintäverkostoja sekä lisätä ymmärrystä työntekijöistä ja heidän tietämyksestään. Tätä kautta sosiaalisen median analytiikka voi edesauttaa myös organisaation toimin- 
nan ennustamista ja kehittämistä. Yhdessä muiden digitaalisten järjestelmien analytiikan sekä erilaisten kyselyiden kanssa sisäisen sosiaalisen median mittaamisella voidaan saada kokonaisvaltaista tietoa organisaation sisäisestä vuorovaikutuksesta, siitä, millaiseksi työntekijät kokevat organisaationsa ja mihin suuntaan he haluavat sitä kehittää. Seuraavat konkreettiset toimenpiteet voivat auttaa sisäisen sosiaalisen median hyödyntämistä organisaation analyyttisena välineenä:

1. Seuraa säännöllisesti sisäisen sosiaalisen median analytiikkaa ja sen kehittymistä. Tarkastele, millä osastoilla ja missä työntekijäryhmissä sosiaalista mediaa käytetään eniten ja missä vähiten. Selvitä, mistä erot johtuvat.

2. Tarkastele sosiaalisen median analyysityökalujen avulla, mistä organisaatiossa puhutaan ja minkälaisissa verkostoissa. Noudattelevatko verkostot organisaatiorajoja vai löytyykö organisaatiosta myös epävirallisia verkostoja ja aktiivisia yhteisöjä virallisten rakenteiden yli? Voitaisiinko näitä itseorganisoituneita yhteisöjä hyödyntää laajemminkin organisaation toiminnassa?

3. Täydennä sisäisestä sosiaalisesta mediasta saatavaa analytiikkaa kyselyillä. Mieti, voiko henkilöstö kyselyitä keventää ja korvata osaa kysymyksistä sosiaalisen median analytiikasta saatavalla tiedolla.
4. Muista, että sisältöjä luetaan, niitä jaetaan ja niistä tykätään monista eri syistä, eikä aktiivisuus jonkin sosiaalisen median aihepiirin ympärillä automaattisesti tarkoita sisällön suosiota tai kannatusta. Laskennallisen analytiikan rinnalla tarvitaankin usein myös laadullisempaa sosiaalisen median analyysia ja tulkintaa.

5. Organisaation sosiaalisen median sisältöjen analysoinnissa tulee muistaa eettiset periaatteet. Millä tasolla henkilöstön tulee olla tietoisia heidän jakamansa sisällön analysoimisesta ja sen hyödyntämisestä organisaation toiminnan kehittämisessä? Miten varmistetaan, että käyttö ei kaadu siihen, että henkilöstö kokee, että heidän viestintäänsä sisäisessä sosiaalisessa mediassa valvotaan tai monitoroidaan?

\section{Näistä voit aloittaa:}

1) Leonardi, P. M., Huysman, M. \& Steinfield, C. (2013). Enterprise social media: Definition, history, and prospects for the study of social technologies in organizations. Journal of Computer - Mediated Communication 19(1), 1-19. http://onlinelibrary.wiley.com/doi/10.1111/jcc4.12029/ full 


\section{LÄHTEET}

Donaldson, S. I. \& Grant-Vallone, E. J. (2002). Understanding self-report bias in organizational behavior research. Journal of Business and Psychology, 17(2), 245-260.

Fombrun, C., Gardberg, N. \& Sever, J. (2000). The reporation Quotient: A multi-stakeholder measure of corporate reputation. The Journal of Brand Management - An International Journal, 7(4), 241-256.

Gilbert, E. (2012). Phrases that signal workplace hierarchy. Teoksessa Proceedings of the ACM 2012 conference on Computer Supported Cooperative Work, 1037-1046). New York, New York, USA: ACM.

Grimmer, J. \& Stewart, B. M. (2013). Text as data: The promise and pitfalls of automatic content analysis methods for political texts. Political Analysis 21(3), 267-297.

Juholin, E. (2009). Innovative communication survey for knowledge-based workplace communities. Report IV. Helsinki: Haaga-Helia ammattikorkeakoulu.

Leonardi, P. M. (2015). Ambient awareness and knowledge acquisition: Using social media to learn" who knows what" and" who knows whom". MIS Quarterly, 39(4), 747-762.

Leonardi, P. M., Huysman, M. \& Steinfield, C. (2013). Enterprise social media: Definition, history, and prospects for the study of social technologies in organizations. Journal of Computer-Mediated Communication, 19(1), 1-19.
Majchrzak, A., Cherbakov, L. \& Ives, B. (2009). Harnessing the power of the crowds with corporate social networking tools: How IBM does it. MIS Quarterly Executive, 8(2), 103-108.

Mann, J., Drakos, N. \& Gotta, M. (2014). Critical capabilities for social software in the workplace. Gartner Research.

Rice, R. E. \& Borgman, C. L. (1983). The use of computer-monitored data in information science and communication research. Journal of the American Society for Information Science, 34(4), 247-256.

Shami, N. S., Muller, M., Pal, A., Masli, M. \& Geyer, W. (2015). Inferring employee engagement from social media. Teoksessa Proceedings of the 33rd Annual ACM Conference on Human Factors in Computing Systems, 3999-4008. New York, New York, USA: ACM.

Shami, N. S., Yang, J., Panc, L., Dugan, C., Ratchford, T., Rasmussen, J. C., Assogba, Y. M., Steier, T., Soule, T., Lupushor, S., Geyer, W., Guy, I. \& Ferrar, J. (2014). Understanding employee social media chatter with enterprise social pulse. Teoksessa Proceedings of the 17th ACM conference on Computer supported cooperative work \& social computing, 379-392. New York, New York, USA: ACM.

Wu, A., DiMicco, J. M. \& Millen, D. R. (2010). Detecting professional versus personal closeness using an enterprise social network site. Teoksessa Proceedings of the SIGCHI conference on human factors in computing systems, 1955-1964). New York, New York, USA: ACM. 
tehokkuutta ja tehdä tietoon perustuvia päätöksiä tehokkuuden parantamiseksi. Käytäntö kuitenkin osoittaa, että merkittävä osa organisaatioista ei hyödy digitaalisen analytiikan tuottamasta datasta vaan ennemminkin hukkuu siihen. Datan menestyksekäs hyödyntäminen edellyttää sitä, että organisaatio kykenee rakentamaan kattavan mutta hallittavissa olevan tehokkuusmittariston. Tämä artikkeli kertoo, miten digitaalisen markkinointiviestinnän tehokkuusmittaristo tulisi rakentaa ja mitä asioita digitaalisen analytiikan hyödyntämisessä tulee ottaa huomioon.

\section{Johdanto: miksi tehokkuuden mittaaminen on tärkeää?}

Markkinointiviestinnän ammattilaisten ei enää toivota mittaavan toimenpiteidensä tehokkuutta; heiltä vaaditaan sitä (McDonald, 2010; Rust, Ambler, Carpenter, Kumar, \& Srivastava, 2004; Stewart, 2009). Tästä huolimatta hyvin harva organisaatio on kyennyt vastaamaan tähän haasteeseen rakentamalla toimivan ja uskottavan mittariston markkinointiviestinnän tehokkuuden mittaamiseksi, raportoimiseksi ja toiminnan kehittämiseksi. Tilanne on markkinointiviestijöiden kannalta huolestuttava, sillä tutkimusten mukaan markkinointiviestijöiden kyky osoittaa toimenpiteidensä tehokkuus vaikuttaa voimakkaasti heidän vaikutusvaltaansa, maineeseensa, yritysjohdon tyytyväisyyteen ja budjetin kokoon organisaation sisällä (Gök, Peker, \& Hacioglu, 2015; O’Sullivan
\& Abela, 2007). Toisaalta mittaaminen on myös lähtökohta tehokkuuden parantamiseksi; jos tuloksia ei mitata, ei koskaan opita, minkälaiset toimenpiteet toimivat paremmin ja minkälaiset huonommin. Markkinointiviestinnän tehokkuuden mittaamisella on siis toisin sanoen kaksi merkittävää roolia: 1) toiminnan tärkeyden osoittaminen ja 2) tulosten hyödyntäminen toiminnan kehittämiseksi.

Optimismia tilanteeseen on tuonut asiakkaiden lisääntyvä digitaalisten medioiden käyttö ja sitä kautta kasvava panostus digitaalisen markkinointiin, jonka tehokkuudesta saadaan yksityiskohtaisempaa tietoa digitaalisten analytiikkatyökalujen avulla (esim. web-analytiikka ja sosiaalisen median monitorointityökalut). Digitaalinen analytiikka tarjoaa hyödyntäjilleen rikasta dataa asiakkaiden käyttäytymisestä. Ydinongelmaksi voidaankin katsoa nimenomaan se, että analytiikan avulla on helppo kerätä paljon tehokkuuteen liittyvää dataa, mutta sen jalostaminen toimintaa ohjaavaksi informaatioksi vaatii resurssien lisäksi hyvin suunnitellun mittariston ja toimivat prosessit tulosten analysoimiseksi ja analyysin muuntamiseksi toimenpiteiksi (Järvinen, 2016; Järvinen \& Karjaluoto, 2015). Tämän artikkelin tavoitteena on tuoda esiin merkittävimmät asiat, jotka organisaatiossa tulisi pitää mielessä tehokkuusmittaristoa rakennettaessa ja hyödynnettäessä.

\section{Mittariston rakentaminen lähtee tavoitteiden asettamisesta}

Markkinoinnin tehokkuuden mittaaminen tarkoittaa mittareiden asettamista suhtees- 
sa markkinoinnin tavoitteisiin ja tavoitteiden saavuttamisen seurantaa näiden mittareiden avulla (Frösén, Luoma, Jaakkola, Tikkanen, \& Aspara, 2016). Määritelmän mukaisesti tavoitteiden asettaminen on siis tehokkuuden mittaamisen lähtökohta. Vaikka tämä voi kuulostaa itsestään selvältä, käytäntö osoittaa, että monissa organisaatioissa markkinointiviestinnän tavoitteilla ja käytössä olevilla mittareilla ei ole välttämättä mitään tekemistä toistensa kanssa. Suurin yksittäinen syy tavoitteiden ja mittareiden erillisyydelle on se, että asetetut tavoitteet ovat liian abstrakteja ja huonosti määriteltyjä, ja näin ollen niitä on mahdotonta mitata (Järvinen \& Karjaluoto, 2015). Esimerkkejä liian abstrakteista tavoitteista ovat $\mathrm{mm}$. innovatiivisen edelläkävijämielikuvan luominen ja asiakkaiden sitouttaminen (engl. customer engagement). Kutsuisin näitä mieluummin visioiksi kuin tavoitteiksi. Tavoitteiksi ne muuttuvat vasta silloin, kun organisaatio kykenee tarkasti määrittelemään, mitä innovatiivinen edelläkävijämielikuva tai engagement todella tarkoittaa ja miten tavoitteen toteutumista mitataan. Tavoitetta, jota ei voi määritellä, ei voi myöskään mitata. Tavoite, jota ei voi mitata, on vain kaunis ajatus, sillä sen toteutumista ei voida koskaan todentaa.

Minkälaisia tavoitteita digitaaliselle markkinointiviestinnälle tulisi sitten asettaa? Ensinnäkin, tavoitteiden tulee olla yhteydessä organisaation strategisiin tavoitteisiin (Ambler, Kokkinaki, \& Puntoni, 2004; Lamberti \& Noci, 2010). Toiseksi, niiden tulee olla fiksuja (smart). George Doran kehitti "SMART goal setting" -mallin 80-luvun alussa (1981), ja vuosien saatossa malli on noussut yhä suurempaan suosioon markkinointi- ja johtamiskirjallisuudessa. SMART ${ }^{1}$ on akronyymi , jonka sanat määrittelevät fiksun tavoitteen kriteerit:

- Specific (tarkoin määritelty)

- Measurable (mitattavissa oleva)

- Attainable (saavutettavissa oleva)

- Relevant (organisaation kannalta merkityksellinen)

- Time-bound (aikaan sidottu)

Esimerkkejä fiksuista digitaalisen markkinointiviestinnän tavoitteista ovat vaikkapa 10 prosentin kasvu verkon kautta hankittavien myyntiliidien määrässä seuraavan kuuden kuukauden aikana, hakukonesijoituksen parantuminen tietyillä (bisnesrelevanteilla) avainsanoilla sijoilta 10-20 sijoille 1-3 vuoden 2017 loppuun mennessä tai brändiin liittyvien sosiaalisen median keskusteluiden valenssi eli keskustelun äänensävyn (positiivinen/neutraali/ negatiivinen) kehittäminen kilpailevia brändejä suhteellisesti positiivisemmaksi vuoden 2018 loppuun mennessä. Nämä ovat fiksuja tavoitteita, koska jokainen niistä on tarkoin määritelty, mitattava, saavutettavissa oleva, merkityksellinen ja aikaan sidottu. Käytännössä tavoitteet on

\footnotetext{
${ }^{1}$ Doranin (1981) alkuperäinen SMART-akronyymi muodostui sanoista: Specific, Measurable, Assignable, Realistic ja Time-related.

Käytännössä myyntiliidi tarkoittaa myyntimahdollisuutta, mutta liidin ominaisuuksiin kuuluu se, että asiakas on itse ilmaissut kiinnostuksensa tuotetta tai palvelua kohtaan eli on jättänyt yhteystietonsa, ladannut tuote-esitteen tai rekisteröitynyt webinaariin tms., jolloin potentiaalisen ostajan perustiedot saadaan talteen.
} 
harvoin määritelty näin tarkasti. Se ei ole välttämättä ongelma, kunhan mittaamisnäkökulma otetaan huomioon tavoitteiden asettamisvaiheessa. Mittarit ovat myös tapa konkretisoida sitä, mitä tavoitteet tarkasti ottaen tarkoittavat.

Fiksuuden lisäksi digitaalisen markkinointiviestinnän tavoitteiden asettamisen tulisi olla moniulotteista aikavälin ja markkinointiviestinnän osa-alueiden suhteen. Osan tavoitteista tulisi keskittyä organisaation pitkän aikavälin menestymiseen ja osan lyhyen aikavälin tuottavuuteen. Vaikka tavoitteet ovatkin aina toimiala-, organisaatio- ja tilannesidonnaisia, voidaan digitaalisen markkinointiviestinnän tavoitteet luokitella karkeasti kolmeen tärkeään luokkaan:

1) myyntitavoitteet (esim. myynti ja myyntiliidit eli myyntimahdollisuudet),

2) bränditavoitteet (esim. näkyvyys, tunnettuus, mielikuva ja kiinnostavuus),

3) asiakkuustavoitteet (esim. kokemus, tyytyväisyys, uskollisuus, sitoutuminen ja suosittelut).

Myyntitavoitteet liittyvät digitaalisen markkinointiviestinnän kykyyn lisätä myyntiä lyhyellä aikavälillä. Bränditavoitteet ovat yhteydessä organisaation pitkän aikavälin potentiaaliin hankkia uusia asiakkaita. Asiakkuustavoitteet liittyvät puolestaan olemassa olevien asiakkaiden säilyttämiseen ja sitä kautta pitkän aikavälin menestymiseen. Menestyäkseen nyt ja tulevaisuudessa organisaation tulee onnis- tua kaikilla näillä kolmella osa-alueella, ja tästä syystä digitaalisen markkinointiviestinnän tavoitteiden tulisi sisältää elementtejä kustakin osa-alueesta. Käytännössä kuitenkin hyvin monet organisaatiot keskittyvät vain yhteen osa-alueeseen; ollaan joko rakastuttu omaan brändiin, puhutaan pelkästä seuraavan kvartaalin myynnistä tai luotetaan sokeasti siihen, että tyytyväiset asiakkaat palaavat ostamaan uudelleen ja kertovat kaikille ystävilleen mahtavasta asiakaskokemuksestaan. Keskittyminen yhteen osa-alueeseen johtaa usein yksiulotteisen mittariston rakentamiseen, kokonaiskuvan hämärtymiseen ja sitä kautta digitaalisen markkinointiviestinnän osaoptimointiin.

\section{Mittareiden valinta}

Digitaalisen markkinointiviestinnän mittareiden valinta on erityisen haastavaa siksi, että digitaalinen analytiikka tarjoaa käytännössä loputtoman määrän erilaisia mittareita, joiden sekaan voi helposti hukkua. Liika innostuminen mittareista voi johtaa tilanteeseen, jossa organisaatio yrittää mitata kaikkea, mutta ei loppujen lopuksi mittaa mitään, sillä mittariston sekavuus tekee tulkinnasta mahdotonta. Kuten edellisessä kappaleessa todettiin, mittareiden tehtävä on mitata tavoitteiden saavuttamista, ja näin ollen mittareiden valitseminen on huomattavasti helpompaa silloin, kun digitaaliselle markkinointiviestinnälle on asetettu selkeät tavoitteet.

Seuraavana haasteena on pohtia, mitkä mittarit sopivat parhaiten kuhunkin tavoitteeseen ja kuinka monta mittaria per tavoite on sopiva määrä. Kumpaankaan 
kysymykseen ei ole olemassa yksiselitteistä vastausta. Tutkimukset kuitenkin osoittavat, että liian kapea mittaristo on riittämätön vangitsemaan markkinointiviestinnän moniulotteiset vaikutukset, kun taas liian leveä mittaristo johtaa helposti tietotulvaan, jolloin mittaristosta ei saada mitään irti (McGovern, Court, Quelch, \& Crawford, 2004; Pauwels et al., 2009). Tehokkuusmittariston tulisi olla monipuolisesti valittu ja näin ollen sisältää lyhyen ja pitkän tähtäimen mittareita, määrällisiä ja laadullisia mittareita sekä eteenpäin ja taaksepäin katsovia mittareita (Ambler \& Roberts, 2008; O'Sullivan \& Abela, 2007). Varsinaisen mittarimäärän pohtimisen sijasta on tärkeämpää kuitenkin keskittyä mittareiden priorisointiin (Chaffey \& Patron, 2012). Organisaation tulisi valita kuhunkin tavoitteeseen liittyvä avainmittari (Key Performance Indicator eli KPI), joka kertoo yksiselitteisesti, saavutettiinko asetettu tavoite vai ei. Muita ns. apumittareita voidaan valita enemmän, ja niiden rooli on tarjota lisäinformaatiota siitä, mitkä tekijät selittävät onnistumista tai epäonnistumista tavoitteen saavuttamisessa.

Mittariston monipuolisuus ei ole tyypillisesti ongelma silloin, kun itse tavoitteet on valittu moniulotteisesti (bränditavoitteet, myyntitavoitteet ja asiakkuustavoitteet), sillä nämä tavoitteet ovat luonteeltaan erilaisia ja ohjaavat monipuolisen mittariston valitsemista. Ydinongelmana onkin vastaavasti se, että tavoitteet on usein valittu yksipuolisesti, jolloin myös mittaaminen on yksiulotteista. Perinteisesti markkinointiviestinnän mittaamisessa on nojattu liikaa bränditutkimuksiin ja asiakastyytyväisyyskyselyihin. Nämä ovat tärkeitä osa-alueita, mutta niitä on helppo kritisoida, sillä markkinointiviestinnän yhteys brändiin ja asiakastyytyväisyyteen sekä näiden asioiden yhteys pitkän aikavälin menestymiseen ei ole yksiselitteinen. Digitaalinen markkinointi ja analytiikka ovat hiljalleen kääntämässä tilanteen päälaelleen, ja keskittyminen on enenevissä määrin suuntautunut lyhyen aikavälin käyttäytymisen ja myyntilukujen seurantaan. Liiallinen myyntilukujen tuijottaminen on kuitenkin niin ikään vaarallista, sillä myyntiluvut keskittyvät menneeseen eivätkä kerro tulevaisuuden kasvunäkymistä.

Kuhunkin osa-alueeseen liittyvät mittarit kannattaa konkretisoida selkeäksi viitekehykseksi, joka havainnollistaa osa-alueen tavoitteet ja mittarien väliset suhteet (Homburg, Artz \& Wieseke, 2012; Järvinen \& Karjaluoto, 2015). Taulukko 1 havainnollistaa esimerkin avulla, miten digitaalisen markkinointiviestinnän myyntitavoitteisiin liittyvät mittarit voisi konkretisoida viitekehykseksi B2B-yrityksen tapauksessa. Huomionarvoista viitekehyksessä on se, miten tavoitteet kytkeytyvät toisiinsa. Liikenteen hankkiminen verkkosivustolle tukee myyntiliidien hankkimista, ja myyntiliidien hankkiminen tukee myynnin kasvua. Näin ollen, jos myyntitavoitteessa jäädään tavoitellusta, voidaan asiaan etsiä syitä muista tavoitteista. Samalla viitekehys konkretisoi aiemmin mainitun avainmittarin ja apumittareiden roolituksen. Esimerkiksi tavoitteen 1 (liikenteen hankkiminen verkkosivustolle) avainmittari on verkko- 


\section{O, / 69}

sivustoistuntojen määrä, joka kertoo sen, päästiinkö tavoitteeseen vai ei. Apumittarit tarjoavat lisäinformaatiota syistä, jotka selittävät tavoitteeseen pääsyä. Jos istuntojen kokonaismäärä on vähentynyt, voidaan tarkastella, mitkä liikenteen lähteet ovat tuoneet vähemmän liikennettä sivustolle edellisvuoteen verrattuna, ja tehdä korvaavia toimenpiteitä kyseisten kanavien käyttöön.

Taulukko 1. Esimerkki B2B-yrityksen myyntitavoitteiden mittaristosta

\begin{tabular}{|c|c|c|c|}
\hline Osa-alue: & Tavoite 1: & Tavoite 2: & Tavoite 3: \\
\hline Myynti & $\begin{array}{l}\text { Liikenteen hankkiminen } \\
\text { verkkosivustolle } \\
\text { (kasvu } 20 \% \text { ) }\end{array}$ & $\begin{array}{l}\text { Online-myyntiliidien } \\
\text { hankkiminen } \\
\text { (kasvu } 20 \% \text { ) }\end{array}$ & $\begin{array}{l}\text { Myynti } \\
\text { (kasvu } 20 \% \text { ) }\end{array}$ \\
\hline $\begin{array}{l}\text { Avainmittari } \\
\text { (KPI) }\end{array}$ & $\begin{array}{l}\text { Verkkosivustoistuntojen } \\
\text { määrä (kasvuprosentti) }\end{array}$ & $\begin{array}{l}\text { Liidien määrä } \\
\text { (kasvuprosentti) }\end{array}$ & $\begin{array}{l}\text { Myyntieurot } \\
\text { (kasvuprosentti) }\end{array}$ \\
\hline Apumittarit & $\begin{array}{l}\text { • Istunnot per kävijä } \\
\text { per kuukausi } \\
\text { • Istuntojen määrä } \\
\text { per liikenteen lähde } \\
\text { (suora, hakukoneet, } \\
\text { display, email, some, } \\
\text { viittaavat sivustot } \\
\text { jne.) }\end{array}$ & $\begin{array}{l}\text { - Liidit per kävijät } \\
\text { (konversiosuhde) } \\
\text { - Heti poistuneet } \\
\text { (bounce rate) } \\
\text { - Sivukatselut/istunto } \\
\text { - Keskimääräinen } \\
\text { istunnon kesto }\end{array}$ & 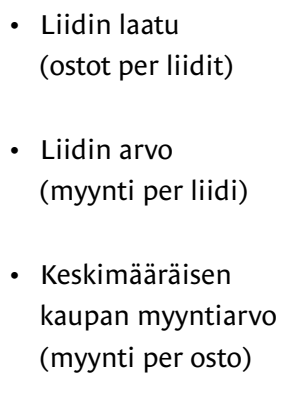 \\
\hline
\end{tabular}


Taulukon esimerkkimittaristo keskittyy pitkälti digitaaliseen analytiikkaan liittyviin mittareihin. Digitaalisen analytiikan tarjoama käyttäytymisdata soveltuukin erinomaisesti digitaalisen markkinointiviestinnän lyhyen aikavälin tuottavuuden mittaamiseen eli käytännössä myynnin ja myyntiä edeltävän käyttäytymisen seurantaan. Vastaavaa taulukkoa brändija asiakkuustavoitteiden osalta on vaikea laatia digitaalisen analytiikan tarjoamilla mittareilla. Syynä on se, että digitaalinen analytiikka ei tarjoa kovin hyviä mittareita asiakkaiden asenteiden, ajatusten ja tunteiden mittaamiseksi, joihin brändi- ja asiakkuustavoitteet pitkälti liittyvät (Järvinen, 2016). Analytiikan avulla pystymme seuraamaan asiakkaiden käyttäytymistä ja käyttäytymiseen johtavia reaktioita (esim. klikkauksia), mutta sen sijaan emme tiedä, mitä asiakkaat ajattelevat tai miten he kokevat viestinnän. Tästä syystä väitteelle, jonka mukaan objektiivisemmat käyttäytymismittarit tulevat korvaamaan subjektiiviset asennemittarit (Seggie, Cavusgil, \& Phelan, 2007), on vaikea löytää vahvoja perusteluja. Vaikka brändi- ja asiakkuustavoitteiden mittaaminen on usein vaikeampaa ja mittaustuloksiin liittyy subjektiivista vääristymää, keskittyminen pelkkiin analytiikkamittareihin voi johtaa lyhyen aikavälin tuottavuuden maksimointiin pitkän aikavälin tehokkuuden kustannuksella (Järvinen, 2016).

Digitaalisen markkinointiviestinnän myyntivaikutuksen mittaamiseen liittyy myös omat haasteensa ja harhaluulonsa. Digitaalisessa analytiikkahuumassa monille on syntynyt illuusio siitä, että analytiikan avulla digitaalisen markkinointiviestinnän tehokkuuden voi yksiselitteisesti linkittää myyntiin tuijottamalla analytiikkatyökalun tuottamia raportteja. On totta, että digitaalisen analytiikan tarjoaman käyttäytymisdatan avulla voidaan melko tarkasti osoittaa, mitkä toimenpiteet ovat olleet yhteydessä asiakkaan ostopäätökseen. Sen sijaan data ei kerro, kuinka paljon tietty toimenpide on vaikuttanut asiakkaan ostopäätökseen tai kokonaismyyntiin. Tämä on merkittävä digitaalisen analytiikan rajoitus, jota monet eivät tunnu ymmärtävän. Monesti kuulee väittämiä, kuten ”Teimme 100 euron AdWords-kampanjan, ja Google Analyticsin mukaan kampanja tuotti 250 euroa myyntiä”. Valitettavasti Google Analytics tai mikään muukaan web-analytiikkatyökalu ei tarjoa tällaista tietoa. Tosiasiassa Google Analytics kertoo, että 100 euron AdWords-kampanja houkutteli sivustolle kävijöitä, jotka ostivat 250 eurolla. Kampanja oli siis yhteydessä 250 euron myyntiin, mutta olisi asiakkaiden täydellistä aliarviointia väittää, että he tekivät ostoksensa puhtaasti kyseisen kampanjan takia. Samanaikaisesti ostopäätökseen vaikutti mahdollisesti useita kymmeniä muita asioita.

Markkinointiviestinnän vaikutusta myyntiin voidaan toki tutkia kehittynein tilastollisin menetelmin (esim. attribuutiomallinnus ja ekonometrinen mallinnus) ja tehdä mallien pohjalta suuntaa antavia arvioita. Mutta vastaus ei löydy missään tapauksessa analytiikkaraporteista, kuten jotkut olettavat. Tästä syystä tutkijalle nousee väistämättä hymy huulille, kun 
hän kuulee väitteen, jonka mukaan yritys X:n tietyn markkinointiviestintäkampanjan ROI on esimerkiksi 46,7 prosenttia. Maailmasta ei löydy ihmistä tai organisaatiota, joka kykenisi arvioimaan minkään kampanjan ROI-prosenttia vastaavalla tarkkuudella. Se, että ROI arvioidaan positiiviseksi, on jo paljon sanottu.

Digitaalisen markkinointiviestinnän mittaamiseen ei ole siis olemassa yhtäkään täydellistä mittaria tai virheetöntä mittausmenetelmää. Tämä johtuu siitä, että markkinointiviestinnän vaikutukset kohdistuvat ihmisiin, ja ihmiset ovat erilaisia. Täysin sama mittaamisongelma koskee kaikkia muita sosiaalitieteen ilmiöitä. Jostain syystä juuri markkinointiviestintää kuitenkin piinaa epärealistinen ajatus siitä, että mittaamisen pitäisi olla jotenkin absoluuttisen tarkkaa. Markkinointiviestinnän tehokkuusmittarit ovat indikaattoreita todellisesta tehokkuudesta. Ne pitää valita tavoitteiden mukaisesti ja riittävän monipuolisesti, jotta ymmärretään viestinnän moniulotteiset vaikutukset.

\section{Mitä tuloksilla tehdään?}

Digitaalisen markkinointiviestinnän mittaaminen on prosessi, joka koostuu seuraavista vaiheista:

1) Datan kerääminen (valittuja mittareita varten)

2) Tulosten raportointi (missä määrin tavoitteet saavutettiin?)

3) Tulosten analysointi ja tulkinta (tulosten taustalla olevien syiden etsintä)

4) Korjaavat toimenpiteet ja testaus (suunnittelu ja toimeenpano)
Datan keräämisen suunnittelu kannattaa toteuttaa mittarien valinnan yhteydessä, sillä ei ole järkeä valita mittareita, joita varten ei voida kerätä dataa. Olennainen kysymys datan keräämisessä on se, millä työkaluilla ja metodeilla keräys tapahtuu. Jos digitaalisen markkinointiviestinnän mittaaminen halutaan toteuttaa moniulotteisesti, tarvitaan tueksi digitaalista analytiikkaa sekä perinteisempiä kyselytutkimuksia. Kun tavoitteet ja mittarit on valittu huolellisesti, tulosten raportointi on suoraviivaista: verrataan tuloksia suhteessa asetettuun tavoitetasoon ja raportoidaan, missä määrin tavoitteissa onnistuttiin. Tulokset kannattaa raportoida säännöllisesti johdolle, sillä tämä johtaa tutkimusten mukaan johdon positiivisempaan suhtautumiseen markkinointiviestintää kohtaan (Pauwels et al., 2009).

Mittaamisprosessin suurin haaste liittyy puolestaan tulosten analysointiin. Analysointi vaatii aikaa ja ennen kaikkea analyyttistä osaamista, josta ei ole runsauden pulaa useimmissa organisaatioissa. Ilman analyysiä dataa ei saada jalostettua informaatioksi, joka ohjaisi suunnittelemaan ja tekemään digitaalisen markkinointiviestinnän tehokkuutta parantavia toimenpiteitä (Chaffey \& Patron, 2012). Tulosten analysoinnissa kannattaa keskittyä erityisesti niihin tavoitteisiin, joiden toteutumisessa on epäonnistuttu. Syvällisen analyysin tekeminen vaatii datan segmentointia, jota varsinkin digitaalisen analytiikan avulla on suhteellisen vaivatonta toteuttaa lukuisilla eri segmentointikriteereillä (liikenteen lähde, aika, sijainti, päätelaite jne.). 
Oletetaan esimerkiksi, että verkkokaupan konversiosuhde jää tavoitetasosta. Segmentoinnin avulla voidaan pureutua mahdollisiin syihin, joiden takia konversiosuhde jäi odotettua alhaisemmaksi. Yksinkertaisena esimerkkinä voidaan selvittää, onko konversiosuhde heikompi niiden kävijöiden osalta, jotka vierailevat sivustolla älypuhelimella. Jos näin on, voidaan olettaa, että ostaminen älypuhelimella ei ole verkkokaupassa riittävän vaivatonta. Seuraavassa vaiheessa siirrytään korjaavien toimenpiteiden suunnitteluun ja esimerkin tapauksessa mietittäisiin, miten ostamisesta älypuhelimella voitaisiin tehdä vaivattomampaa (esim. skaalautuuko sivusto älypuhelimille käyttäjäystävällisesti tai kysytäänkö tilauslomakkeella liikaa asioita?) Suunnittelun pohjalta muodostetaan hypoteesi tai hypoteeseja (esim. tilauslomakkeen yksinkertaistaminen johtaa parempaan konversiosuhteeseen älypuhelimilla). Tämän jälkeen testataan hypoteesien paikkansapitävyys (esim. A/B-testillä) ja onnistuneet testit implementoidaan pysyvästi. Digitaalisen markkinointiviestinnän mittaamisen perimmäisenä ajatuksena on jatkuva oppiminen ja tehokkuuden parantaminen mitattujen tulosten pohjalta.

\section{Lopuksi: Kehitä mittaamista askel kerrallaan}

Hyvän digitaalisen markkinointiviestinnän mittariston rakentaminen ja hyödyntäminen on oppimisprosessi. Toisin sanoen ei kannata yrittää haukata liian isoa palaa kerralla, sillä siihen saattaa tukehtua. Suosittelen etenemään askel kerrallaan ja samalla kartuttamaan ymmärrystä ja kokemusta mittaamisesta seuraavien vaiheiden mukaisesti:

\section{1) Aloita mitattavien tavoitteiden} asettamisesta. Valitse aluksi esimerkiksi kolme organisaation kannalta merkittävintä tavoitetta, joiden toteutumista on mahdollista mitata. Suosittelen aloittamaan myyntiin liittyvistä tavoitteista, koska
A) niiden mittaaminen on suhteellisesti helpompaa digitaalisen analytiikan avulla ja B) myyntiin liittyvät tulokset kiinnostavat tavallisesti johtoa eniten. Kun pystyt analytiikan avulla osoittamaan digitaalisen markkinointiviestinnän yhteyden myyntiin, olet paremmassa neuvotteluasemassa budjetin suhteen. Isompi budjetti puolestaan mahdollistaa lisäresurssien hankinnan laadukkaan viestinnän toteuttamiseksi ja entistä paremman mittariston rakentamiseksi.

2) Valitse yksi avainmittari per tavoite ja muutama apumittari avainmittarin tueksi. Älä valitse liian montaa mittaria, sillä se ainoastaan hankaloittaa tulkintaa.

3) Kokoa mittaristo yksinkertaiseen viitekehykseen, joka havainnollistaa tavoitteiden ja mittareiden keskinäiset suhteet (Taulukko 1).

4) Raportoi digitaalisen markkinointiviestinnän tulokset johdolle säännöl- 
lisesti ja pyydä heiltä palautetta.

5) Kun mittariston perusrunko on kasassa, kehitä kykyäsi analysoida tuloksia. Keskity ensisijaisesti niihin tavoitteisiin, jotka ovat jääneet toteutumatta. Segmentoi dataa ja pyri löytämään syitä odotuksia heikommille tuloksille.

6) Tee testejä tulosten parantamiseksi ja keskity tehokkuuden jatkuvaan optimointiin.

7) Tarkastele tavoitteitasi ja mittaristoa aika ajoin kriittisesti ja pohdi niiden heikkouksia. Kiinnitä eri tyisesti huomiota siihen, onko mittaristo riittävän moniulotteinen. Ottaako se huomioon sekä lyhyen aikavälin tuottavuuden että pitkän aikavälin tehokkuuden?

\section{Näistä voit aloittaa:}

Järvinen, J. \& Karjaluoto, H. (2015). The use of Web analytics for digital marketing performance measurement. Industrial Marketing Management, 50, 117-127. Saatavilla verkossa: https://www.researchgate. net/publication/275589681_The_use_of_ Web_analytics_for_digital_marketing_performance_measurement

Järvinen, J. (2016). The Use of Digital Analytics for Measuring and Optimizing Digital Marketing Performance. Väitöskirja, Jyväskylän yliopisto. Saatavilla verkossa: https://jyx.jyu.fi/dspace/bitstream/hand- le/123456789/51512/978-951-39-6777-2_vaitos21102016.pdf?sequence $=1$

\section{LÄHTEET}

Ambler, T., Kokkinaki, F. \& Puntoni, S. (2004). Assessing marketing performance: Reasons for metrics selection. Journal of Marketing Management, 20(3-4), 475-498.

Ambler, T. \& Roberts, J. H. (2008). Assessing marketing performance: Don't settle for a silver metric. Journal of Marketing Management, 24(7-8), 733-750.

Chaffey, D. \& Patron, M. (2012). From Web analytics to digital marketing optimization: Increasing the commercial value of digital analytics. Journal of Direct, Data and Digital Marketing Practice, 14(1), 30-45.

Doran, G. T. (1981). There's a S.M.A.R.T. way to write managements's goals and objectives. Management Review, 70(11), 35-36.

Frösén, J., Luoma, J., Jaakkola, M., Tikkanen, H. \& Aspara, J. (2016). What Counts Versus What Can Be Counted: The Complex Interplay of Market Orientation and Marketing Performance Measurement. Journal of Marketing, 80(3), 60-78.

Gök, O., Peker, S. \& Hacioglu, G. (2015). The marketing department's reputation in the firm. European Management Journal, 33(5), 366-380. 
Homburg, C., Artz, M. \& Wieseke, J. (2012).

Marketing performance measurement systems: Does comprehensiveness really improve performance? Journal of Marketing, 76(May), 56-77.

Järvinen, J. (2016). The Use of Digital Analytics for Measuring and Optimizing Digital Marketing Performance. Jyväskylä Studies in Business and Economics, 170, Dissertation thesis.

Järvinen, J. \& Karjaluoto, H. (2015). The use of Web analytics for digital marketing performance measurement. Industrial Marketing Management, 50, 117-127.

Lamberti, L. \& Noci, G. (2010). Marketing strategy and marketing performance measurement system: Exploring the relationship. European Management Journal, 28(2), 139-152.

McDonald, M. (2010). A brief review of marketing accountability, and a research agenda. Journal of Business \& Industrial Marketing, 25(5), 383-394.

McGovern, G. J., Court, D., Quelch, J. A. \& Crawford, B. (2004). Bringing customers into the boardroom. Harvard Business Review, 82 (November), 70-80.

O’Sullivan, D. \& Abela, A. V. (2007). Marketing performance measurement ability and firm performance. Journal of Marketing, 71(April), 79-93.
Pauwels, K., Ambler, T., Clark, B. H., LaPointe, P., Reibstein, D., Skiera, B., Wierenga, B. \& Wiesel, T. (2009). Dashboards as a service: Why, what, how, and what research is needed? Journal of Service Research, 12(2), 175-189.

Rust, R. T., Ambler, T., Carpenter, G. S., Kumar, V. \& Srivastava, R. K. (2004). Measuring marketing productivity: Current knowledge and future directions. Journal of Marketing, 68(October), 76-89.

Seggie, S. H., Cavusgil, E. \& Phelan, S. E. (2007). Measurement of return on marketing investment: A conceptual framework and the future of marketing metrics. Industrial Marketing Management, 36(6), 834-841.

Stewart, D. W. (2009). Marketing accountability: Linking marketing actions to financial results. Journal of Business Research, 62(6), 636-643. 

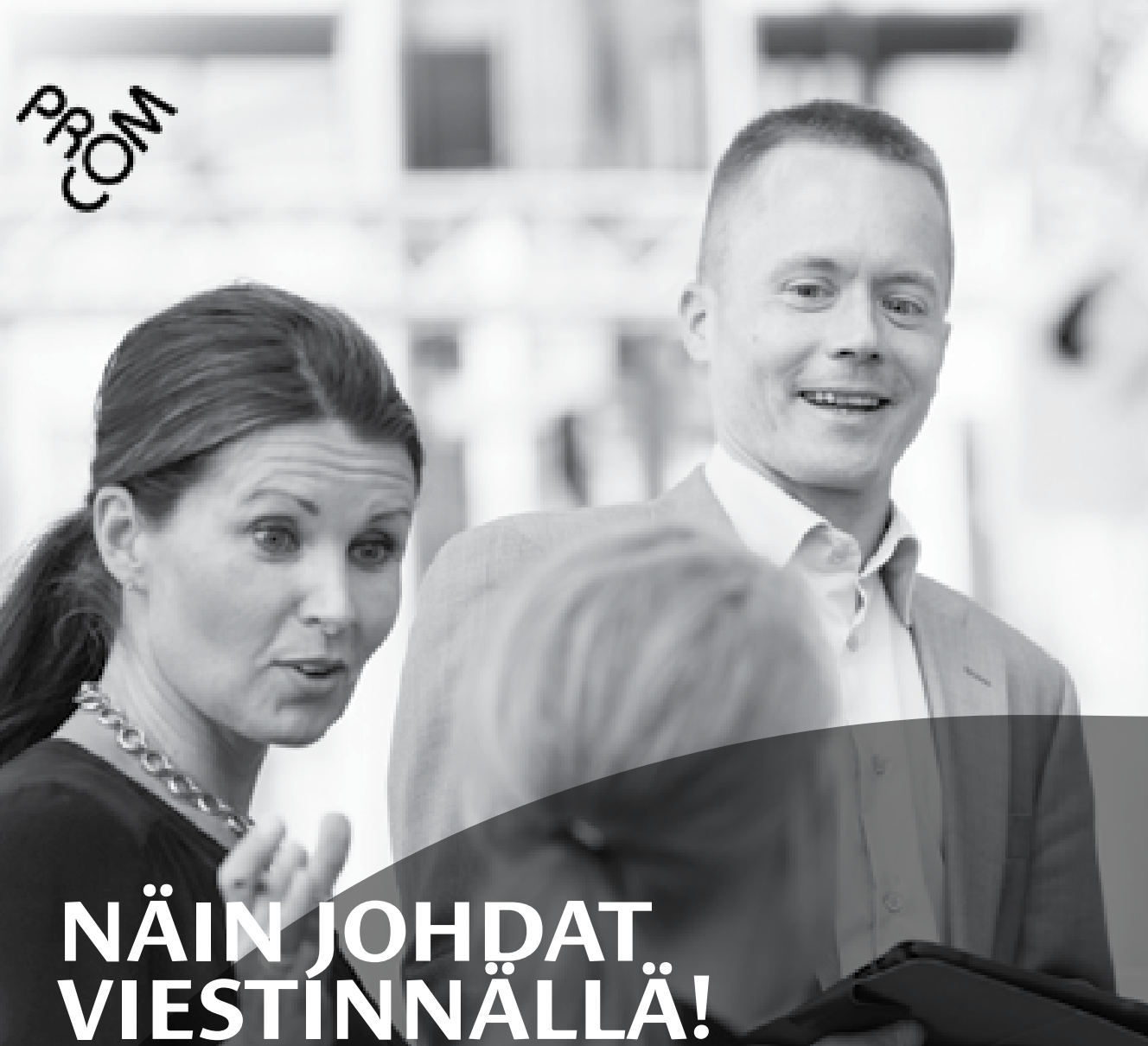

- Verkkokoulutus esimiehille

Vuorovaikutuksen merkitys työpaikoilla huomataan vasta, kun asiat menevät pieleen.

ProComin uusi, itseopiskeluna suoritettava verkkokoulutus opastaa käytännönläheisesti kaikkia esimiehiä onnistumaan paremmin johtajina.

31.7. asti saat koulutuksen hinnasta $-15 \%$ alennuksen (norm. 159 e / 189 e + alv. 24 \%). Käytä koodia "ProComma".

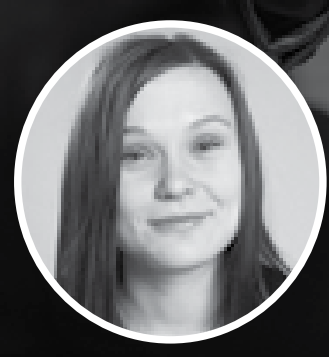

Valmentajana toimii tutkijatohtori Anne Laajalahti Jyväskylän yliopistosta. 


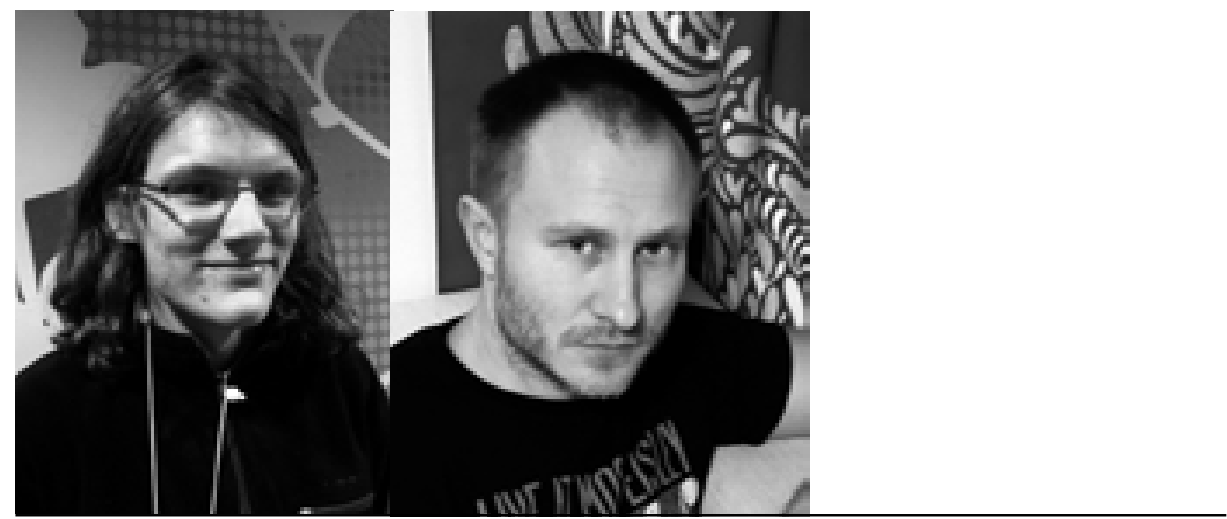

KETKÄ?

\section{Matti Nelimarkka ja Reijo Sund}

- Matti Nelimarkka on Helsingin yliopiston jatko-opiskelija ja Aaltoyliopiston tutkija. Hänellä on sekä yhteiskuntatieteen että tietojenkäsittelytieteen tutkinnot. Hänen tutkimusaiheensa pureutuvat sosiaalisen laskennan alalle: hän kehittää ja tutkii erityisesti uusia vuorovaikutteisia sovelluksia sekä analysoi ihmisten välistä tietokonevälitteistä ja tietokonetuettua vuorovaikutusta. Nelimarkka on Rajapinta ry:n puheenjohtaja sekä perustajajäsen ja opettaa laskennallista yhteiskuntatiedettä Helsingin yliopistolla.

Reijo Sund toimii Helsingin yliopiston yhteiskuntatieteiden menetelmäkeskuksen johtajana sekä professorina Itä-Suomen yliopistossa. Hän on soveltavan tilastotieteen dosentti, ja hänen tutkimuskiinnostuksensa ovat kohdistuneet ensisijaisesti isojen rekisteriaineistojen analysointiin liittyviin metodologisiin kysymyksiin sekä tilastolliseen tietojenkäsittelyyn niin yhteiskuntakuin terveystieteisiin kuuluvissa sovelluksissa. Sund on osallistunut myös avoimeen lähdekoodiin perustuvien tilastollisten ohjelmistojen kehittämiseen. 


\section{VIESTINNÄN MITTAAMINEN BIG DATAN AVULLA}

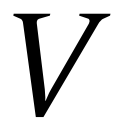
iime aikoina monella yhteiskuntatieteiden alalla yhdeksi uudenlaiseksi ja lupaavaksi tutkimusmahdollisuudeksi on noussut massadatan (big data) käyttö, niin myös viestintätieteissä. Yleisellä tasolla uudenlainen tutkimustapa on kiinnostanut erityisesti sosiaalisen median palveluiden analyysissä, kuten Twitterin ja Facebookin kohdalla (esimerkiksi Zhang \& Counts, 2015; Bruns \& Highfield, 2013; Hemphill \& Roback, 2014; Graham et al., 2013), mutta massadatan analyysiin kehitettyjä menetelmiä on käytetty myös perinteisen media-aineiston analyysiin (esimerkiksi Levy \& Franklin, 2013; Burscher, Vliegenthart \& De Vreese, 2015). Kohteena ovat olleet myös tekstipohjaiset aineistot - joihin rajaudumme tässä työssä - vaikkakin viime aikoina myös kuvien, videoiden sekä äänen analyysiin on kehitetty paljon uusia menetelmiä.
Riippuen puhujasta massadata saattaa viitata paitsi aineistoon myös menetelmällisiin lähestymistapoihin aineiston analyysissä. Mielestämme yhteiskuntatieteellisen tutkimuksen yhteydessä nämä uudet laskennalliset analyysimenetelmät ovat jopa kiinnostavampia kuin itse massadata. Analyysimenetelmiin keskittymällä vältämme varsin turhauttavan keskustelun massadatan koosta ja eroista ei-massadataan. Nämä menetelmät tukevat perinteisiä kyselytutkimuksen ja haastatteluaineistojen laadullisia ja määrällisiä analyysitapoja. Laskennallisen yhteiskuntatieteen piirissä suosittuja menetelmiä ovat olleet koneoppiminen, verkostoanalyysi sekä simulaatiomallit (Cioffi-Revilla, 2010). Lisäksi erityisesti datan visualisoinnin kautta vuorovaikutteisten järjestelmien käyttö tarjoaa analyyseihin mielekästä lisäsisältöä.

Tässä lyhyessä katsauksessa käsittelemme viestinnän mittaamista laskennallisilla menetelmillä. Mittaaminen keskittyy usein saavutetun viestinnän arvon mittaamiseen suhteessa kustannuksiin; mittareita voivat esimerkiksi olla uusien kommenttien lukumäärä sosiaalisessa mediassa (heijastelee aktiivisuutta) kuin uutisotsikoihin nousseet viestit (heijastelevat ulkoista näkyvyyttä). Aloitamme määrittelemällä, mitä tarkoitamme massadatalla ja kuvaamalla yleisellä tasolla sen analysointimenetelmiä. Tämän jälkeen käsittelemme neljä erilaista näkökulmaa mittaamiseen: määrällisen, laadullisen, tilastollisen sekä ennustavan. Päätämme katsauksen arvioimalla, mihin massadata ja sen menetelmät soveltuvat sekä eivät sovellu viestinnän mittaamisen analyy- 
sissä ja kuinka massadataa voi hyödyntää viestintäalan ammattilaisena.

\section{Big data ja analyysimenetelmiä}

Viimeisten muutaman vuoden aikana termi "Big data" on noussut yhdeksi muotitermiksi, jota ryöstöviljellään miltei alalla kuin alalla (Sund, 2015). Usein tuntuu lisäksi olevan epäselvää, mitä termillä missäkin yhteydessä tarkoitetaan. Suomenkielisen Wikipedian mukaan "Big data on erittäin suurten, järjestelemättömien, jatkuvasti lisääntyvien tietomassojen keräämistä, säilyttämistä, jakamista, etsimistä, analysointia sekä esittämistä tilastotiedettä ja tietotekniikkaa hyödyntäen.” (Wikipedia, 2017.) Kyseisessä määritelmässä on pyritty tietynasteiseen arvovapauteen, mutta muotitermiksi nouseminen on vaatinut uskoa massadatan huomattavaan taloudellisen hyödyntämisen potentiaaliin. Massadatasta puhuttaessa törmätäänkin usein hehkutukseen, jossa erilaiset (yritysten) tietovarannot luvataan taianomaisesti muuttaa (liiketoimintaa tukevaksi) hyödylliseksi informaatioksi. Ennen massadataa (2010-luku) käytännössä samasta asiasta puhuttiin ainakin liiketoimintatiedon hallinnan (business intelligence, 2000-luku), tiedonlouhinnan (data mining, 1990-luku) ja asiantuntijajärjestelmien (expert systems, 1980-luku) nimillä, mutta ne eivät onnistuneet täyttämään monia suurista lupauksistaan. Keskeinen syy siihen, etteivät ne nousseet valtavirran analyysiksi, oli liiallinen usko datan objektiivisuuteen sekä keskittyminen teknologiaan eikä varsinaisiin empiirisen tutkimuksen perustavanlaatuisin haasteisiin.
On tarpeen korostaa, ettei datan määrää lisäämällä voida ohittaa empiirisen tutkimuksen perusoletuksia tai rajoituksia. Erilaiset käsitykset aineistojen tavasta heijastella todellisuutta johtavat myös erilaisiin metodologisiin valintoihin. Jos mitattavat asiat ovat suoraan havaittavia, kuten esimerkiksi lähetettyjen viestien lukumäärä, on niitä varsin helppoa tarkastella siten, että jokainen ymmärtää asian samalla tavalla. Jos taas ollaan kiinnostuneita toisentyyppisistä kysymyksistä, metodologinen tilanne on monimutkaisempi. Esimerkiksi kun kysytään, miksi joku viesti on lähetetty, sitä harvoin pystytään mittaamaan käytettävissä olevasta aineistosta millään itsestään selvällä tavalla. Tässä suhteessa yhteiskuntatieteet ovat tyypillisiltä tutkimuskysymyksiltään eriytyneet suorempaan havainnointiin perustuvista tieteistä. Tämä on ongelmallista siinä mielessä, että menetelmien soveltaminen tilanteissa, joissa tutkimuskysymys tai aineisto ei ole sopusoinnussa menetelmän kannalta oleellisten metodologisten oletusten kanssa, johtaa usein kestämättömiin tulkintoihin ja pahimmillaan karkeisiin virhepäätelmiin. Lisähaasteita aiheuttaa vielä se, että käytännössä kaikki massadatat ovat luonteeltaan sekundaarisia, eli niitä ei alun perin ole tuotettu nimenomaan kyseessä olevaa tutkimusta varten. Varsinkin sosiaalisen median aineistojen osalta on myös ongelmallista, että yhteiskunnalliset ilmiöt ja itse sosiaalinen media voivat vaikuttaa hyvin nopeasti syntyvän aineiston luonteeseen, jolloin tutkimuksen tai vastaavan asetelman toistaminen myöhemmin ei välttä- 
mättä enää onnistu - esimerkiksi Twitterin keskusteluissa yksilöiden Twitterin käyttö sekä tulkinnat aiheiden kiinnostavuudesta muokkaavat tämän median sisältöä (Jungherr, Schoen \& Jürgens, 2016).

Käytännössä nämä rajoitukset tarkoittavat sitä, että kysymyksenasettelua joudutaan muokkaamaan sellaiseksi, että siihen pystytään vastaamaan käytettävissä olevalla aineistolla. Tämä on vaikeaa, kun tarkastellaan moniulotteisia ilmiöitä kuten viestinnän mittaamista, ja vaatii varsin laajaa taustatietämystä aiheesta ennen kuin edes yritetään soveltaa laskennallista analyysiä (Boyd \& Crawford, 2012). Ilman ilmiötä ja tarkasteltavan aineiston syntyhistoriaa koskevaa taustatietämystä päädytään täysin aineistolähtöiseen tutkimukseen, joka ei yleensä milloinkaan ole tarkoituksenmukaista. Taustatietämyksen lisäksi tarvitaan osaamista myös laskennallisten menetelmien käytöstä ja isojen aineistojen käsittelystä, joten onnistuneeseen tutkimukseen tarvitaankin välttämättä yhteiskuntatieteen ja laskennallisen osaamisen yhdistämistä (Halavais, 2015).

\section{Laskennallinen näkökulma viestinnän mittaamiseen}

Yksinkertaisin lähestymistapa viestinnän mittaamiseen on laskea lukumääriä. Laskennalliset menetelmät ovat erinomainen tapa tuottaa lukumäärätietoa laajoista aineistoista, erityisesti jos aineistolle on tarpeen tehdä jotain esikäsittelyä - kuten muuttaa sanat perusmuotoon - ennen laskentaa. Yleisesti erilaiset kuvailevat tunnusluvut ovat yksinkertaisin, usein tosin alkeellinen, tapa mitata viestintää isoista aineistomassoista. Esimerkiksi viestien määrä, jakauma ajan suhteen sekä viestien tyypit (kommentteja, vastauksia, linkkien jakoja yms.) ovat yleisesti käytössä olevia mittareita (esimerkiksi Marttila et al., 2016; Merry, 2014; Graham et al., 2013). Usein tulokset ovat kiinnostavia, mutta varsin vaillinaisia - ilmiötä pystytään kyllä kuvailemaan, mutta ei välttämättä täsmällisemmin erottelemaan ilmiön laatua.

Myös verkostoanalyysia käytetään usein viestinnällisen datan analyysiin. Verkostoanalyysissä ilmiö kuvataan toimijoiden välisiksi suhteiksi, verkoksi jossa havainnoidaan toimijoiden ('solmujen') välille muodostuvia yhteyksiä ('kaaria'). Solmujen ja kaarien kautta voidaan laskea useita verkkoa kuvaavia tunnuslukuja, kuten aste, joka mittaa solmuun tulevien kaarien määrää, tai havainnoida millaisia yhteisöjä verkossa syntyy. Perinteinen verkostoanalyysin sovellus viestinnän mittaamisessa on tutkia sosiaalisen median vuorovaikutussuhteita tietyn tapahtuman aikana. Esimerkiksi Larsson (2013) on tutkinut, kuinka katsojat ja esiintyjät viestivät toisilleen television puheohjelmien aikana. Samoin Bruns ja Highfield (2013) tarkastelevat verkostoanalyysin menetelmiä käyttäen vuorovaikutusta vaalien alla eri toimijaryhmien (ehdokkaat, media, kansalaiset jne.) välillä. Tämänkaltaisella lähestymistavalla voidaan arvioida, onnistuuko viestintä luomaan monensuuntaista vuorovaikutusta vai tapahtuuko vuorovaikutus vain viestijän ja yleisön välillä, jolloin vuorovaikutuksellisuudesta huolimatta ei välttämättä synny laajaa keskustelua. 


\section{Sisällön analyysi isojen aineistojen aikana}

Edellä kuvattua määrällistä tapaa on kuitenkin helppo kritisoida viestin varsinaisen sisällön huomiotta jättämisestä. Vaikka sisällön ja merkitysten analyysi on selvästi haastavampaa kuin lukumäärien tarkastelu, myös koneelliseen sisällön analyysiin on kehitetty menetelmiä. Yksi lähestymistapa on sentimenttianalyysi (esim. Thelwall et al., 2010), jonka avulla voidaan arvioida viestin sisältöä positiivisella ja negatiivisella akselilla. Laskennalliset menetelmät ovat saavuttaneet paljon suosiota, sillä niitä käyttämällä saadaan näennäisesti analysoitua sellaisiakin isoja aineistoja, joiden sisältämän tekstimäärän lukeminen veisi vuosikausia. Monissa tilanteissa näiden menetelmien toiminta voi kuitenkin olla ristiriitaista - esimerkiksi ironian tulkinta on haastavaa niin ihmisille kuin tietokoneille - tai viestin negatiivinen ilmaus koskeekin jotain muuta kuin viestissä mainittuja viestijöitä. Lisäksi sentimenttianalyysi perustuu usein sanalistoihin positiivisista ja negatiivisista ilmaisuista; kuitenkin näiden sanalistojen validiteetti - eli kuinka hyvin sanalistat kuvaavat positiivisia ja negatiivisia tunteita, erityisesti englannista suomeksi käännetyissä listoissa - voi olla todella huono. Laskennallisen sisällönanalyysin menetelmiä käytettäessä tulisikin aina edes jossain määrin pyrkiä arvioimaan koneellisen tulkinnan tarkoituksenmukaisuutta lukemalla joitain alkuperäisiä tekstejä ja vertaamalla koneen tulkintaa inhimilliseen tulkintaan (Grimmer \& Stewart, 2013). Muuten käy helposti niin, että aletaan tehdä tulkintoja vain laskennallisen menetelmän tuloksista eikä varsinaisesta sisällöstä. Silloin päädytään usein sellaiseen virhepäätelmään, jossa saadaan kyllä laskennallisessa mielessä oikeita vastauksia, mutta ei niihin kysymyksiin joihin haluttaisiin.

Jonkin teoreettisesti pohjustetun kehikon käyttäminen viestien luokitteluun on harvemmin viestinnän määrällisessä mittauksessa sovellettu mutta mielekäs apuväline viestien lukumäärän laskemisen yhteyteen. Yleisesti tällaista lähestymistapaa kutsutaan määrällisissä analyyseissa datan rikastamiseksi, eli käytännössä hyödynnetään analyyseissa taustatietämystä, jota ei aineistosta sinänsä suoraan löydy mutta jonka mukaisesti aineiston voi kuitenkin epäsuorasti olettaa käyttäytyvän. Tätä voidaan tehdä monella tavalla, mutta yksi todella kätevä laskennallinen keino on käyttää ohjattua koneoppimista: ensin opetetaan tietokonetta esimerkkien avulla, minkä jälkeen tietokone voi käyttää oppimaansa luokittelua hyvin nopeasti suuriinkin aineistoihin. Opettamalla tietokonetta luokittelemaan sisältöjä olemassa olevien (mahdollisesti teoreettisesti mielekkäiden) luokitusten kautta voidaan tehostaa aineiston analyysiä merkittävästi. Esimerkiksi Stromer-Galley et al. (2016) toteuttivat Yhdysvaltojen 2016 presidentinvaaleihin sovelluksen, joka luokitteli ehdokkaiden sosiaalisen median viestejä niiden viestintätarkoituksen perusteella, esimerkiksi tunnisti hyökkäävyyttä sekä imagon ylläpitoa.

Monissa tapauksissa on mahdollista käyttää analyysiin myös etäisyysmittoihin 
perustuvaa ryhmittelyanalyysia tai ohjaamatonta koneoppimista, joissa pyritään puhtaasti laskennallisin keinoin ryhmittelemään aineistoa. Tällöin ei siis ole tarpeen opettaa koneelle luokittelua (kuten ohjatussa koneoppimisessa), vaan kone muodostaa itsenäisesti mahdollisia luokitteluja ja ihmisen tehtäväksi jää näiden tulkinta. Viime aikoina aihemallinnus (topic modeling) on kerännyt suosiota (Blei, 2012). Aihemallinnuksessa tietokone ryhmittelee aineiston sanoja ryhmiin. Jokaiselle "dokumentille" (=yhdelle tekstiaineistoille) lasketaan todennäköisyys kuulua tiettyyn aiheeseen eli ryhmittelyn mukaiseen termi- ja dokumenttijoukkoon. Aiheet ovat koneen havaitsemia yleisiä sanoja, jotka esiintyvät useimmiten joissain tietyissä dokumenteissa. Aiheille annetaan myöhemmin merkitys tarkastelemalla näitä sanoja. Menetelmää on sovellettu Suomessa esimerkiksi vaalijulkisuuden havainnointiin. Vuoden 2015 vaalien lehdistöjulkisuudessa voitiin koneellisesti löytää 40 erilaista politiikkaan liittyvää aihekokonaisuutta (esimerkiksi energiapolitiikka, lapsiperheet sekä valtiontalous). Nämä aihekokonaisuudet löydettiin aineistosta ilman etukäteen annettua luokittelua (Nelimarkka et al., arvioitavana).

\section{Tilastolliset menetelmät ja big data}

Yllä kuvatut menetelmät ovat kuitenkin luonteeltaan kuvailevia, ne eivät sellaisenaan kerro vielä syy-seuraussuhteista jotka ovat usein mielenkiinnon kohteena myös viestinnän mittauksessa. Syy-seuraussuhteita tarkasteltaessa käytetään tyypillisesti konfirmatorista lähestymistapaa, jossa perinteiseen määrällisen tutkimuksen tapaan asetetaan ensin hypoteesi ja tarkastellaan sitten sen toteutumista tilastollisilla testeillä. Esimerkiksi Laaksonen et al. (2017) uskoivat, että ehdokkaat ovat hyökkäävämpiä, jos he kommentoivat kilpailevan puolueen ehdokkaan sisältöjä Facebookissa kuin jos he kommentoivat oman puolueensa ehdokkaan sisältöjä. Negatiivinen viestintä tunnistettiin laskennallisesti sentimenttianalyysillä, ja viestien sentimenttien jakaumaa tarkasteltiin perinteisellä tilastollisella testaamisella.

Syy-seuraussuhteen tarkastelemiseksi ilmiö tyypillisesti operationalisoidaan aiemman teorian ja tutkimuskirjallisuuden avulla. Operationalisoinnissa yhdistetään tutkimuksellinen käsite erilaisiin mittareihin, esimerkiksi kyselytutkimuksessa joukko kysymyksiä operationalisoidaan tarkoittamaan yhteiskuntatieteellisesti kiinnostavaa käsitettä. Tämä operationalisointi ja teoreettinen pohdinta voidaan myös laskennallisten menetelmien hengessä formuloida algoritmiksi, tietokoneohjelmaksi, joka tekee aineistolle mielekkään operationalisoinnin. Esimerkiksi Digivaalit 2015 -hankkeessa ehdokkaan vaikuttavuutta perinteisen median agendaan mitattiin tarkastelemalla, mainitsiko ehdokas sosiaalisessa mediassa poliittisesti mielenkiintoisen ilmiön ennen kuin siitä puhuttiin perinteisessä mediassa. Kyseessä on siis aikasarja-analyysin eräs sovellus, jolla mitattiin ehdokkaiden mahdollisuuksia tai potentiaalia vaikuttaa median agendaan. Näin laskettiin vaikuttajaindeksiä ehdokkaille. Myöhemmin hankkeessa tarkasteltiin taustatekijöiden, kuten iän, 
sukupuolen sekä puolueaseman vaikutusta vaikuttajaindeksiin regressioanalyysissä ja havaittiin esimerkiksi eduskunnassa olevilla puolueilla olevan suuremmat vaikuttaja-indeksit median agendaan (Nelimarkka et al., arvioitavana).

\section{Ennustaminen ja ennakointi massadatalla}

Massadatalla pyritään usein ennustamaan tulevaisuutta. Klassinen esimerkki on Googlen aikanaan kehittämä flunssan ennustaminen ihmisten hakutermejä tarkastelemalla. Vaikka myöhemmin kyseinen tutkimustulos havaittiin pätemättömäksi (tiivistelmä kritiikistä, esim. Lazer et al., 2014), se on edelleen usein esillä. Esimerkiksi Suomessa samankaltaista lähestymistapaa on käytetty työttömyysasteen ennustamiseen. Ideana näissä ennustavissa malleissa on käyttää kerättyä historiallista massadataa ja yhdistää näitä aineistoja havaittuihin käytösmalleihin.

Ennustaminen on usealle viestinnän alalle mielekäs alue. Esimerkiksi markkinoinnissa tulevaisuuden ennustaminen voisi usein olla hyödyllistä kuluttajien tarpeiden havaitsemiseksi. Vaalien tuloksen ennustamiseen voidaan käyttää vaikkapa sosiaalisen median viestintää, millä saavutetaan usein melko tarkkoja tuloksia. Tosin, kuten Gayo-Avello (2013) huomauttaa, ei näissä tutkimuksissa - lupauksista huolimatta - ennusteta vaalitulosta, vaan usein enemmänkin kehitetään malleja, jotka selittävät edellisten vaalien tuloksia. Eli esimerkiksi viestien määrään, niiden sentimentteihin ja viestimäärän muutoksiin perustuva selittävä malli estimoidaan käyttäen edellisiä vaaleja kuvaavaa dataa ja uskotaan, että samanlainen malli voisi päivitetyllä datalla toimia myös seuraavien vaalien tarkastelussa.

\section{Mihin laskennalliset menetelmät soveltuvat?}

Periaatteessa laskennalliset menetelmät ovat hyvin samankaltaisia kuin perinteisemmätkin tilastotieteen menetelmät. Massadatan kanssa käytettäväksi kehitettyinä niillä on kuitenkin muutamia keskeisiä etuja. Ne skaalautuvat ja automatisoituvat, eli aineiston määrällä ei ole erityistä merkitystä käsittelyn kannalta ja samankaltainen analyysiprosessi voidaan suorittaa yksinkertaisesti uudelleen. Toisaalta laskennallisilla menetelmillä ja massadatalla on oikein käytettynä mahdollista tarkastella asioita toisenlaisesta näkökulmasta, joka voi tarkentaa tunnettua kuvaa ilmiöistä tai jopa paljastaa täysin uudenlaisia ilmiöitä. Tämän vuoksi niitä onkin luonnehdittu yhteiskuntatieteiden mikroskoopiksi (Lazer et al., 2009).

Skaalautuminen ja automatisoituminen mahdollistavat myös viestinnän reaaliaikaisen analyysin. Yllä mainitsemamme Yhdysvaltojen presidentinvaalianalyysi (Stromer-Galley et al., 2016) esimerkiksi tarjosi toimittajille mahdollisuuden tarkastella ehdokkaiden Twitter-aktiivisuutta päivittäin ja käyttää tätä omissa uutisissaan. Samoin erilaiset vuorovaikutteiset järjestelmät voivat hyödyntää koneellisesti tehtyä luokittelua. Kaye et al. (2012) halusivat parantaa yrityksen työntekijöiden tietoisuutta tuotteista käytävästä keskustelusta sosiaalisessa mediassa. He rakensivat 
kahvihuoneeseen julkisen näytön, missä näytettiin tuotteita käsitteleviä positiivisia sekä negatiivisia viestejä sekä positiivisten ja negatiivisten viestien määrää. Näin jokainen kahvihuoneen käyttäjä tuli tietoiseksi yrityksen senhetkisestä maineesta ja "pöhinästä" sosiaalisessa mediassa.

Suuret lupaukset uusista analyysimahdollisuuksista ja löydöksistä massadatan ja laskennallisten menetelmien avulla ovat kuitenkin toistaiseksi jääneet varsin epämääräisiksi kokeiluiksi. Tällä viitataan erityisesti ohjaamattomaan koneoppimiseen ja sen sovelluksiin yhteiskuntatieteissä, jolloin siis suurten lupausten toteutuminen olisi eräänlainen aineistovetoisen (vs. teoriavetoisen) tutkimuksen paluu. Entuudestaan tuttua laajaa keskustelua on herättänyt kysymys teorian merkityksestä ja tarpeesta ilmiöiden tulkinnassa, niin akateemisessa kuin käytännöllisemmässä ammattitoiminnassa (kansainvälisestä keskustelusta, esimerkiksi Halavais, 2015; Kitchin, 2014; Boyd \& Crawford, 2012). Tätäkin oleellisempi keskustelu liittyy kuitenkin epistemologisiin ja metodologisiin periaatteisiin; keskustelun seurauksena määrällinen yhteiskuntatieteellinen tutkimus aikaisemmin leimattiin positivistiseksi ja pinnalliseksi. Tämä suuntaus johti aikoinaan laadullisten lähestymistapojen korostumiseen, mutta se joutuu nyt käytännössä mukautumaan tilanteeseen, jossa pitäisi pystyä analysoimaan myös sekundaarisia massatekstiaineistoja. Emme usko emmekä toivo näiden uusien laskennallisten menetelmien korvaavan välttämätöntä yhteiskuntatieteelliseen tutkimukseen kuuluvaa teoriakeskustelua, mutta toivomme niiden johtavan tarkoituksenmukaisella tavalla määrällisten menetelmien arvostuksen palautumiseen ja niiden oikeutetun käytön yleistymiseen.

Yksi erittäin potentiaalinen mahdollisuus on pyrkiä tukemaan massadatalla sekä laskennallisilla menetelmillä muilla tavoin saatuja havaintoja. Esimerkiksi etnografiaa voidaan käyttää yhdessä laskennallisten menetelmien kanssa tukemaan aineiston keräämisessä ja analyysissä sekä ohjaamaan havaintojen muodostamisessa (Laaksonen et al., 2017). Myös sekundaaristen aineistojen ymmärtämiseen tähtäävälle dataetnografialle olisi tarvetta.

Viime aikoina on tapahtunut merkittävää kehitystä massadatan soveltamisessa myös muihin kuin tekstiaineistoihin, esimerkiksi kuviin. Kuvista voidaan yllättävän tarkasti tunnistaa sen sisältöjä (objekteja) ja luokitella kuvia näiden sisältöjen suhteen. Samoin esimerkiksi videoanalyysi perustuu tämänkaltaisen kuva-analyysin soveltamiseen, mutta sarjalle kuvia. Näiltäkään osin massadatan ja laskennallisten menetelmien mahdollisuuksia ei tule siis sivuuttaa.

\section{Mitä massadatalla ei voi mitata?}

Eräs massadataan liittyvä haave on korvata perinteiset kyselytutkimukset nopeammilla ja kustannustehokkaammilla, esimerkiksi verkkokeskusteluiden aineistoihin perustuvilla lähestymistavoilla (GonzalezBailon \& Paltoglou, 2015; Jungherr et al., 2016). Yhteiskuntatieteissä ollaan kuitenkin oltu yleisesti varsin skeptisiä tämän suhteen, koska verkkokeskustelut eivät ole oikein missään mielessä edustava otos; ne 
perustuvat henkilön päätökseen ilmaista mielipiteensä sosiaalisessa mediassa (Jungherr, Schoen \& Jürgens, 2016). Samoin esimerkiksi tapahtumien osallistujien määrän mittaaminen sosiaalisen median aktiivisuuden perusteella kärsii vastaavasta ongelmasta; sosiaalisen median aineisto voi mitata vain niitä henkilöitä, jotka haluavat kertoa olevansa tapahtumassa sosiaalisessa mediassa. Samankaltaisia ongelmia voi esiintyä myös muissa aineistoissa, esimerkiksi yrityksen aineisto kuluttajan ostoksista ei sisällä kilpailevan kauppaketjun aineistoa. Eräs keino onkin välttää tulosten yleistämistä tietyn ympäristön ulkopuolelle; esimerkiksi analyysiä Twitteristä ei ole syytä yleistää Twitterin ulkopuolelle.

Yllä käsittelimme jo kahta muuta haastetta, aineistojen sekundaarisuutta - eli sitä, että ne on tyypillisesti muodostettu muihin kuin ennalta tunnettuihin tutkimustarkoituksiin - kuin myös sitä, että monet yhteiskunnalliset ilmiöt muuttavat nopeasti muotoaan tavalla, joka heijastuu myös aineistoihin. Nämä rajoitukset eivät välttämättä haittaa kontekstiin tiukasti sidotuissa kuvailevissa tutkimuksissa, mutta jos niitä ei oteta tai pystytä ottamaan riittävällä tavalla huomioon tutkimuksessa, on vaarana ajautua joksikin aikaa tilanteeseen, jossa joka tuutista alkaa tulla huonolaatuisia, puhtaasti menetelmien ja aineistojen ehdoilla tuotettuja selvityksiä kunnollisen oivaltavan ja uutta luovan yhteiskuntatutkimuksen sijaan.

\section{Big data ja yhteisöviestintä - mitä seuraavaksi?}

Ensimmäinen - ja mielestämme suurin - haaste massadatan soveltamisessa on pystyä muotoilemaan kysymys, joka tukee viestintätarpeita ja johon voi uskottavasti vastata massadatan avulla. Useilla yrityksillä on tarjolla esimerkiksi sosiaalisen median analytiikkaan välineitä, mutta niiden kohdalla on syytä olla tarkkaavainen: kuvaavatko mittarit sitä mitä niiden pitäisi kuvata, ja onko lähestymistapa uskottava. Esimerkiksi mainitsemamme sentimenttianalyysivälineet ovat usein, erityisesti suomeksi, vielä alkutekijöissään.

Valmiiden välineiden etu on niiden kustannustehokkuus; toinen vaihtoehto on pyrkiä saamaan yrityksen sisälle viestinnällisen massadatan osaamista. Osaamista voi ostaa useilta ohjelmistoyrityksiltä, mutta myös ilmaista koulutusta laskennallisen datan analyysiin on tarjolla - esimerkiksi MOOC-alustoilla verkkokursseina. Jos tätä taitoa pyritään kehittämään yrityksessä, kannattaa turvautua ilmaisiin ja avoimiin data-analyysiympäristöihin ja datan analyysityökaluihin, kuten R-ohjelmointikieleen tai Python-kieleen ja sen scikit-learn-paketteihin. Molempiin näistä on saatavissa apua ja tutoriaaleja useista internetlähteistä.

\section{Lopuksi}

Kuten esimerkkimme näyttivät, laskennalliset menetelmät ovat monipuolinen ja uusia mahdollisuuksia avaava lähestymistapa viestinnän mittaamiseen. Tekstiaineistojen lisäksi löytyy vaihtoehtoisia tapoja niin kuvien, videoiden kuin tilastojenkin analyy- 
siin. Suurin haaste liittyykin alati kasvaviin vaatimuksiin erilaisista tutkimustaidoista, joita onnistuneeseen analyysiin tarvitaan. Kuten Kitchin (2014) huomautti, myös yhteiskuntatieteellistä analyysia tarvitaan laskennallisen analyysin tekemiseksi yhteiskuntatieteissä. Tämä vaatii sekä tiivistä yhteistyötä menetelmäosaajien ja substanssiosaajien välillä että vähintäänkin yhteisen keskustelun mahdollistavaa peruskäsitystä niin menetelmistä kuin substanssistakin (Sund, 2003).

\section{Kiitokset}

Matti Nelimarkka kiittää Koneen Säätiötä sekä TEKESiä (hanke: Smarter Social Media Analytics) rahoituksesta tutkimukselle.

Kiitämme myös kahta nimetöntä arvioitsijaa artikkelin kommenteista, jotka selkeyttivät ja kehittivät artikkelia.

\section{Näistä voit aloittaa}

Grimmer, J. \& Brandon M. S. (2013).

Text as Data: The Promise and Pitfalls of Automatic Content Analysis Methods for Political Texts. Political Analysis 21(3): 267-297.

Jungherr, A., Harald S. \& Pascal J. (2016). The Mediation of Politics through Twitter: An Analysis of Messages Posted during the Campaign for the German Federal Election 2013. Journal of Computer-Mediated Communication 21(1): 50-68.

\section{KIRJALLISUUS}

Blei, David M. (2012). Probabilistic Topic Models. Communications of the ACM 55(4): 77-84.

Boyd, Danah \& Kate Crawford (2012). Critical Questions for Big Data. Information, Communication \& Society 15(5). Routledge: 662-79.

Bruns, Axel \& Tim Highfield (2013). Political Networks on Twitter. Information, Communication \& Society 16(5). Routledge: 667-691.

Burscher, B., Vliegenthart, R. \& De Vreese, C. H. (2015). Using Supervised Machine Learning to Code Policy Issues: Can Classifiers Generalize across Contexts? The ANNALS of the American Academy of Political and Social Science 659(1): $122-31$.

Cioffi-Revilla, C. (2010). Computational Social Science. Wiley Interdisciplinary Reviews: Computational Statistics 2(3): 259-71.

Gayo-Avello, D. 2013. A Meta-Analysis of Stateof-the-Art Electoral Prediction From Twitter Data. Social Science Computer Review 31(6): 649-79.

Gonzalez-Bailon, S. \& Paltoglou, G. (2015). Signals of Public Opinion in Online Communication: A Comparison of Methods and Data Sources. The ANNALS of the American Academy of Political and Social Science 659(1): 95-107.

Graham, T., Broersma, M., Hazelhoff, K. \& van 't Haar, G. (2013). Between Broadcasting Political Messages and Interacting With Voters. The Use of Twitter during the 2010 UK General Election Campaign. Information, Communication \& Society 16(5): 692-716. 


\section{O, I 86}

Grimmer, J. \& Brandon M. S. (2013). Text as Data: The Promise and Pitfalls of Automatic Content Analysis Methods for Political Texts. Political Analysis 21(3): 267-97.

Halavais, A. (2015). Bigger Sociological Imaginations: Framing Big Social Data Theory and Methods. Information, Communication \& Society 4462 (June). 1-12.

Hemphill, L. \& Andrew J. R. (2014). Tweet Acts: How Constituents Lobby Congress via Twitter. Teoksessa Proceedings of the 17th ACM Conference on Computer Supported Cooperative Work \& Social Computing - CSCW '14, 1200-1210. New York, New York, USA: ACM Press.

Jungherr, A., Schoen, H. \& Jürgens, P. (2016). The Mediation of Politics through Twitter: An Analysis of Messages Posted during the Campaign for the German Federal Election 2013. Journal of Computer-Mediated Communication 21(1): 50-68.

Jungherr, A., Schoen, H., Posegga, O. \& Jürgens, P. (2016). Digital Trace Data in the Study of Public Opinion. An Indicator of Attention Toward Politics Rather Than Political Support. Social Science Computer Review, (online-first).

Kaye, J., Lillie, A., Jagdish, D., Walkup, J. Parada, R. \& Mori, K. (2012). Nokia Internet Pulse. Proceedings of the 2012 ACM Annual Conference Extended Abstracts on Human Factors in Computing Systems Extended Abstracts - CHI EA '12: 829-844.
Kitchin, R. (2014). Big Data, New Epistemologies and Paradigm Shifts. Big Data \& Society 1(1): 1-12.

Laaksonen, S.-M., Nelimarkka, M., Tuokko, M., Marttila, M Kekkonen, A., Villi, M. (2017). Working the fields of big data: Using big-data-augmented online ethnography to study candidate-candidate interaction at election time. Information Technology \& Politics 14(1):1-22.

Larsson, A. O. (2013). Tweeting the Viewer - Use of Twitter in a Talk Show Context. Journal of Broadcasting \& Electronic Media 57(2): 135-52.

Lazer, D., Kennedy, R., King, G. \& Vespignani, A. (2014). The Parable of Google Flu: Traps in Big Data Analysis. Science 343 (6167): 1203-1205.

Lazer, D., Pentland, A., Adamic, L., Aral, S., Barabasi, A.-L., Brewer, D., Christakis, N. et al. (2009). Social Science. Computational Social Science. Science (New York, N.Y.) 323: 721-23.

Levy, K. E. C. \& Franklin, M. (2013). Driving Regulation: Using Topic Models to Examine Political Contention in the U.S. Trucking Industry. Social Science Computer Review 32 (December): 182-94.

Marttila, M., Laaksonen, S-M., Kekkonen, A., Tuokko, M. \& Nelimarkka, M. (2016). Digitaalinen Vaaliteltta: Twitter Politiikan Areenana Eduskuntavaaleissa 2015. Teoksessa Grönlund, K. \& Wass H. (toim.) Eduskuntavaalitutkimus 2015: Poliittisen Osallistumisen Eriytyminen, 117-37. Helsinki: Oikeusministeriö. 
Merry, M. K. (2014). Broadcast Versus Interaction: Environmental Groups' Use of Twitter. Journal of Information Technology \& Politics 11(3): 329-44.

Nelimarkka, M., Laaksonen, S.-M., Marttila, M., Kekkonen, A., Tuokko, M. \& Villi, M. (julkaisematon käskikirjoitus). Influencing the agenda through social media: Online agenda building and normalization during a pre-electoral campaign period.

Stromer-Galley et al. (2016). Illuminating 2016. http://illuminating.ischool.syr.edu/

Sund, R. (2003). Utilisation of Administrative Registers Using Scientific Knowledge Discovery. Intelligent Data Analysis 7(6): 501-19.

Sund, R. (2015). Miksi isoon dataan hukutaan? Tieto \& Trendit - Talous ja hyvinvointikatsaus 2/2015: 40-45.

Thelwall, M., Buckley, K., Paltoglou, G., Cai, D. \& Kappas, A. (2010). Sentiment in Short Strength Detection Informal Text. Journal of the American Society for Information Science and Technology 61(12): 2544-2558.

Wikipedia 2017. Big data. Luettu 30.1.2017. https://fi.wikipedia.org/wiki/Big_data

Zhang, A. X. \& Counts, S. (2015). Modeling Ideology and Predicting Policy Change with Social Media. Teoksessa Proceedings of the 33rd Annual ACM Conference on Human Factors in Computing Systems - CHI '15, 2603-12. New York, New York, USA: ACM Press. 


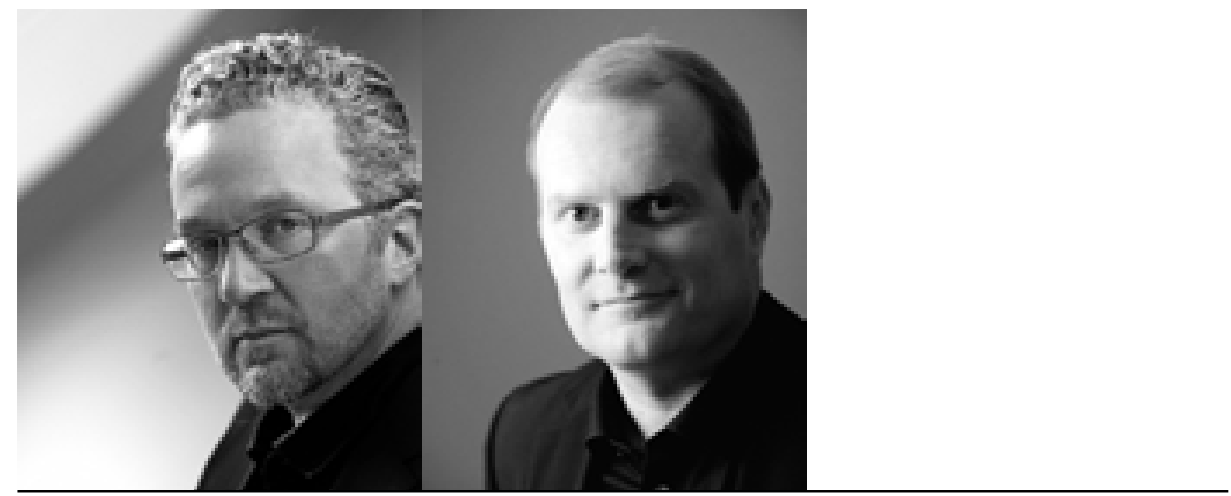

KETKÄ?

\section{Pekka Aula ja Jouni Heinonen}

- Professori Pekka Aula on Suomalaisen Tiedeakatemian pääsihteeri ja viestinnän tutkija. Aiemmin hän on toiminut muun muassa Helsingin yliopiston professorina vuosina 2004-2013 ja 2015 ja Lappeenrannan teknillisen yliopiston (LUT) professorina vuonna 2014. Kansainvälistä tutkimustyötä Aula on tehnyt Amsterdamin ja Stanfordin yliopistoissa. Aula on väitellyt valtiotieteiden tohtoriksi Helsingin yliopistosta vuonna 1999. Aula on tutkimustyössään erikoistunut organisaatioiden viestintään, viestintäympäristön muutoksiin, maineen ja maineenhallinnan kysymyksiin. Hän on julkaissut useita tieteellisiä ja populaareja kirjoja ja artikkeleita niin Suomessa kuin kansainvälisestikin.

VTM Jouni Heinonen on maineenhallintaan erikoistuneen viestintätoimisto Pohjoisranta Burson-Marstellerin hallituksen puheenjohtaja ja seniorikonsultti. Työssään hän konsultoi yrityksiä ja yhteisöjä maineen ja viestinnän strategisissa kysymyksissä. Heinosella on noin 20 vuoden kokemus mainetutkimusten suunnittelusta, toteuttamisesta ja kehittämisestä. Jouni Heinonen on kirjoittanut maineesta useita kirjoja ja hän on myös suosittu luennoitsija. 
MAINEEN MITTAAMINEN

SOMEDIALISAATION

AIKAKAUDELLA

$M$ aine on organisaation ulkopuolisten, yleensä sidosryhmien, tekemä arvio organisaatiosta (Brown \& Dacin, 1997; Barnett et al., 2006; Chun, 2005) ja näissä arvioinneissa organisaatio määrittyy hyväksi tai huonoksi. Hyvämaineiset organisaatiot ovatkin yleisesti ottaen hyvin tunnettuja, vetovoimaisia ja arvostettuja (Fombrun, 1996; Rindova et al., 2006; Pfarrer, et al., 2010). Mainetta pidetään organisaation, eritoten yritysten tärkeimpänä strategisena omaisuutena (Flanagan \& O'Shaughnessy, 2005) ja maineeseen kohdistuvia riskejä pidetään yhtenä kaikkein vahingollisimmista uhista aikamme organisaatioille (esim. Murray, 2003).
Maine on tutkimuskohteena suosittu ja maailmanlaajuinen. Kattavasti eri tieteenaloja seuraavan Scopus-tietokannan mukaan maailmassa on 2000-luvulla julkaistu runsaat 29000 tieteellistä vertaisarvioitua tutkimusta maineesta. Yksistään vuonna 2016 julkaisujen määrä oli yli 2500. Organisaatiomaineeseen keskittyneet tutkijat ovat kiinnittäneet huomiota siihen, miten yrityksen strateginen johtaminen voisi saavuttaa hyötyjä myönteisestä ja esimerkiksi kilpailijoita paremmasta maineesta (esim. Rhee \& Valdez, 2009; Rindova et al., 2006; Hutton et al., 2001). Tutkimukset osoittavat, että hyvä maine on monin tavoin kohteelleen eduksi ja että maineriski on aina uhka, joka voi toteutuessaan aiheuttaa esimerkiksi kilpailukyvyn heikkenemistä, sidosryhmien lojaalisuuden heikentymistä ja yritystoiminnan legitimiteetin vähenemistä (Rayner, 2003).

Viestinnän käytännön toimijoiden kannalta erityisen kiinnostavia ovat väitteet, joiden mukaan yksi keskeisimmistä ammatillisista haasteista ovat maineen arviointiin, mittaamiseen ja hallintaan liittyvät lainalaisuudet ja ongelmat erityisesti uuden viestintäteknologian ja sosiaalisen median (Aula, 2016; Aula \& Heinonen, 2016) aikakaudella. Maineestaan välittävät organisaatiot toimivat avoimuuden ja aktiivisen kommunikoinnin paineessa, jota lisäävät yhteiskunnan, politiikan ja talouden medioituminen - näkemyksemme ja kokemuksemme maailmasta ovat yhä enenevämmin riippuvaisia moninaisesta mediasta. Mediasta onkin tullut yhä kiinteämpi organisaatioiden toimintaym- 
päristöä määrittävä tekijä. Medioituneessa ympäristöstä organisaatiot muokkaavat toimintatapojaan vastaamaan vallitsevaa medialogiikkaa, kuten lähetysaikoja, tuotantorutiineja ja esitysformaatteja (ks. Ampuja et al., 2014). Julkisuudesta on tullut monille organisaatioille tavoite itsessään.

Ajatus medioituneesta toimintaympäristöstä on tyypillisesti rakentunut niin sanotun perinteisen median (sanomalehdet, radio, TV) organisaatioiden toimintaa ohjaaville reunaehdoille. Aikamme toimintaympäristön kuvaukseen on kuitenkin välttämätöntä sisällyttää mukaan sosiaalinen media. Voidaankin ajatella, että viestintäympäristön digitalisoituminen ja sosiaalisen median nousu on altistanut organisaatiot somedialisaation (Aula, 2016; Aula \& Heinonen, 2016) vaikutusvallalle. Somedialisaation ydinajatus aikamme toimintaympäristön kuvaajana on, että paitsi yhteiskunnan organisaatiot ja instituutiot niin myös perinteinen media itsessään joutuu yhä enenevässä määrin sovittamaan toimintaansa, kuten sisällöntuotannon muotoa ja jakelua, sosiaalisen median vaateisiin. Ilmeisin mikrotason esimerkki lienee niin sanottu klikkijournalismi. Makrotasolla ilmiö tiivistyy esimerkiksi Facebookin vuoden 2015 ilmoitukseen, jossa se kertoi sisällyttävänsä perinteisen median sisältöjä omaan palveluunsa. Facebookin käyttäjän ei enää tarvitse klikata itseään mediayhtiön sivuille, vaan sisältö on integroituneena palveluun. Samalla Facebook teki itsestään median ilman omaa sisällöntuotantoa ja siihen sidottuja resursseja ja vastuita. Lisäksi somedialisaatio ohjaa perinteisen median omia palveluja. Sanomalehtien verkkosivut muistuttavat sosiaalisen median palveluja jakopainikkeineen ja kommentointimahdollisuuksineen. Yleisradion TV-uutisten lähetyksessä on toimittajien Twitter-tunnus ja Helsingin Sanomien juttujen yhteydessä on Facebook- ja Twitter-jakomahdollisuudet. Somedialisaation päätepisteeksi voidaan ajatella täydellisesti toisiinsa sulautunut media, jossa jako perinteiseen ja sosiaaliseen mediaan menettää lopulta merkityksensä.

\section{Mittaamisen välttämättömyysvaade}

Somedialisaation luonnehtimassa liiketoimintaympäristössä perustellun tiedon jano on suuri. Viestien ja myös disinformaation määrä on alati kasvava. Samaan aikaan yhä harvempi pystyy erottamaan olennaisen epäolennaisesta. Tukea päätöksille haetaan tutkimuksesta, mutta usein unohdetaan katsoa tutkimuksen taakse; miten tutkimus on tehty, keneltä asioita on kysytty, miten aineisto on analysoitu ja niin edelleen. Mitä tahansa selvitystä ei kuitenkaan voida määrittää tutkimukseksi. Tällä on erityistä merkitystä, sillä pätevästä tutkimustiedosta on tullut uskottavuuden ja luottamuksen valuuttaa. Kiinnostavaa on myös, että erilaisilla mainelistauksilla (rankings) on valtaa. $\mathrm{Ne}$ osaltaan vaikuttavat siihen, miten tärkeät sidosryhmät havaitsevat ja hahmottavat brändejä ja miten ne arvioivat yrityksiä tai niiden johtajia. Vaikka mainelistauksia on hyödynnetty myös akateemisissa tutkimuksissa, niitä kohtaan on esitetty myös aiheellista kritiikkiä (Eberl, 2006). Kritiikki kohdistuu yleisimmin siihen, että 
mainelistaukset perustuvat vain yhden tai kapeasti määritellyn sidosryhmän, kuten yritysjohtajien mielipiteisiin (Renner, 2011).

Järjestelmällisellä maineen rakentamisella ei saada riittäviä hyötyjä, mikäli toimintojen ja niiden tuloksellisuuden monitorointiin ei kiinnitetä riittävästi huomiota. Taustaoletus tälle havainnolle on yksinkertainen: mainetta ei voida rakentaa menestyksellisesti, jos emme tiedä mitä maine tiettynä hetkenä on tai miten tehdyt toimenpiteet muuttavat vallitsevaa tilannetta. Tästä seuraa, että maineen rakentamisen ja hallinnan prosesseihin on välttämätöntä sisällyttää tekojen monitorointi. Vain jatkuva toimenpiteiden ja niiden seurausten arviointi takaa suurimman mahdollisen hyödyn.

Mittaamisen välttämättömyysvaateesta huolimatta monet organisaatiot eivät katso tarpeelliseksi investoida käyttökelpoisiin, päteviin maineen mittausmenetelmiin. Eikä maine ole poikkeus, vaan pikemminkin vahvistaa säännön. Yleisemminkin ottaen viestinnän arviointi on vajaata ja monet käytetyistä menetelmistä eivät kestä tieteellisen analyyttistä tarkastelua. Tilanne on paradoksaalinen. Viestintään, sen kaikissa muodoissaan, käytetään yhä enemmän resursseja, mutta jos niitä allokoidaan vajain perustein ilman selkeää tavoiteasetantaa ja seurantaa, voivat seuraukset olla arvaamattomia. Tilanne on kyseenalainen sikälikin, että samaan aikaan organisaatioissa korostetaan työn tuottavuuden ja toimenpiteiden tuloksellisuuden merkitystä. Erityisen riskialtista on, jos viestintästrategioissa selkeästi määriteltyjen, operatiivisesti tarkkojen viestinnän tavoitteiden ja niiden toteutumisen seuranta saavat vain vähän huomiota.

\section{Maineen mittausmenetelmät}

Ennen kuin mainetta voidaan menestyksekkäästi mitata, seurata ja hallita tarvitaan kolmen tason tietoa (Genasi, 2001): Ensimmäisen tason tieto koskee sitä, kenellä tai millä ryhmillä on organisaatioiden kannalta erityistä merkitystä. Keskeinen kysymys kuuluu, missä sidosryhmissä organisaatio haluaa olla maineeltaan hyvä. Tiedon toisella tasolla kysytään, millä asioilla on organisaatiolle erityistä merkitystä. Yhtäältä organisaatiossa halutaan tietää, mitkä tekijät ovat merkityksellisiä, kun sidosryhmät muodostavat käsityksensä organisaatiosta, ja millä organisaatioon liittyvillä tekijöillä on sidosryhmille erityistä merkitystä. Toisaalta oleellisia ovat organisaation toimialaan liittyvät merkitykselliset tekijät. Esimerkiksi tietotekniikka-alalla on oletettavaa, että maineen kannalta merkitykselliset asiat ovat hyvin erilaisia tai ne voivat painottua eri tavalla kuin metsäalalla. Tiedon toisella tasolla ovat lisäksi oleellisia organisaatioiden sisäiset asiat: mitkä ovat ne maineen tekijät, jotka ovat oman organisaation kannalta merkityksellisiä. Kolmas tiedon taso on maineen mittaamisen taso. Oleellista on määritellä, minkälaisen maineen organisaatio haluaa. Keskeistä on myös pohtia, miten organisaatio tietää, että sen maine on muuttunut ja mitkä tekijät ovat vaikuttaneet maineen muuttumiseen.

Maineen järjestelmällisessä arvioinnissa keskeisiä ovat mittauksiin käytetyt 
tiedonkeruumenetelmät. Karkeasti ottaen nämä voidaan jakaa neljään ryhmään, jotka eivät ole toisiaan poissulkevia. Yleistä, ja suositeltavaa, on erilaisten tiedonkeruumenetelmien yhdisteleminen eli ns. mix-methods-asetelmat. Yhdysvaltalainen mainetutkija Craig Carroll (2016) on laatinut hyödyllisen jaottelun eri tiedonhankintamenetelmistä: niin sanotut kirjoituspöytä- ja sekundaari-menetelmät, laadulliset menetelmät, määrälliset menetelmät sekä online- ja mobiilimenetelmät.

\section{Taulukko 1.}

Maineen mittaamisen tiedonhankintamenetelmiä (Carroll, 2016)

\begin{tabular}{|l:l:l:l}
$\begin{array}{l}\text { Kirjoituspöytä- } \\
\text { ja sekundaariset } \\
\text { tutkimukset }\end{array}$ & $\begin{array}{l}\text { Laadullinen } \\
\text { tutkimus }\end{array}$ & $\begin{array}{l}\text { Määrällinen } \\
\text { tutkimus }\end{array}$ & $\begin{array}{l}\text { Online-ja } \\
\text { mobiilitutkimus }\end{array}$ \\
\hline $\begin{array}{l}\text { Arkistotutkimus } \\
\text { Syndikoidut }\end{array}$ & Haastattelut & Kyselytutkimukset & $\begin{array}{l}\text { Sosiaalisen median } \\
\text { analyysit }\end{array}$ \\
$\begin{array}{l}\text { Historiallinen } \\
\text { tutkimus }\end{array}$ & Fokusryhmät & Sisällön analyysi & Verkkosivun \\
& Kehystutkimus & Koeasetelmat & optimointianalyysit \\
& Tapaustutkimus & &
\end{tabular}


Sekudaarimenetelmissä hyödynnetään jo olemassa olevia tai muiden keräämiä aineistoja. Usein kyseessä on niin sanottu syndikoitu, useiden toimijoiden yhdessä tekemä tai teettämä datankeruu tai tutkimus. Mainetutkimuksessa tunnettuja datalähteitä ovat esimerkiksi Nilsenin yleisömittaukset ja BuzzMetrics ja trendi- ja kuluttajakäyttäytymistä seuraavat kaupalliset toimijat, kuten Yankelovich, Ketchum ja Suomessakin paljon siteerattu Edelmanin luottamus-barometri. Myös akateemiset mainetutkimukset ovat käyttökelpoisia oman organisaation maineanalyysin lähteitä samoin kuin organisaation omat dokumentit ja muut arkistolähteet.

Laadulliset mittaukset tarjoavat parhaimmillaan rikkaan, yksityiskohtaisen ja syvälle menevän käsityksen organisaation maineesta, siihen liittyvistä näkemyksistä, mielipiteistä ja arvostuksista. Tyypillisiä tiedonkeruumenetelmiä ovat henkilöhaastattelut, fokusryhmät tai erilaiset tarinankerronta- ja sana-assosiaatiomenetelmät.

Määrällistä mainetutkimusta varten data kerätään tyypillisesti kyselytutkimuksilla ja analysoidaan erilailla tilastollisilla menetelmillä. Tunnettuja survey-perusteisia maineenmittareita ovat muun muassa konsulttiyritysten omistamat Rep Track (Reputation Institute) ja Brand Z (WPP) -mittarit. Suomessa vastaavia menetelmiä ovat Pohjoisranta Burson-Marstellerin RepMap ja T-median Luottamus\&Maine-mittarit.

Aineistona voivat toimia myös erilaiset media- tai muut tekstit, joita analysoidaan sisältöanalyysimenetelmillä. Mahdollista on myös erilaisten koeasetelmien käyttö, joissa esimerkiksi etsitään maineen eri osatekijöiden syy-seurausuhdetta taloudellista menestystä kuvaaviin mittareihin.

Näiden lisäksi on vielä yhä suurempaa suosiota keränneet online- tai mobiilidatan keräys- ja analyysimenetelmät. Eritoten monipuolinen Facebook- ja Twitter-analytiikka tarjoaa kiinnostavan, vaikka vielä vähän hyödynnetyn mahdollisuuden maineen mittaamiseen ja arviointiin. Kaupallisen puolen sosiaalisen median maineanalytiikkaa soveltaa muun muassa suomalainen Underhood. Myös niin sanotun big data -analytiikan mahdollisuudet ovat moninaiset ja ilmeiset.

Myös uudet viestintä- ja markkinointitutkimuksen muodot ovat todistaneet käyttökelpoisuutensa mainetutkimuksessa. Esimerkiksi psykofysiologisia tutkimusmenetelmiä on sovellettu menestyksekkäästi tutkittaessa organisaation maineen vaikutuksia organisaatiota koskevien uutisten vastaanottoon (Ravaja et al., 2015; Aula, 2016) ja mediayritysten maineen vaikutusta kuluttajien käyttäytymiseen (Laaksonen et al., 2013). Samoin yleisöjen käyttäytymiseen perustava analytiikka on vahvassa nousussa.

Uusien menetelmien oraalla olevasta noususta huolimatta on perusteltua väittää, että suomalainen käytäntöä palveleva mainetutkimuksen - ja myös viestintätutkimuksen - valtavirta nojaa vahvasti kyselytutkimuksiin. Vain harvoin organisaatiot ovat valmiita investoimaan enemmän resursseja vaativiin laadullisiin tutkimuksiin ja laadullisia menetelmiä soveltavaan analytiikkaan tai määrällisten ja laadullisten menetelmien yhdistämi- 
seen. Harmillista on, että valtaosa kyselymenetelmiä käyttävistä kaupallisista maine-, brändi- ja viestintäselvityksistä ei kestä lähempää menetelmällistä tarkastelua. Ongelmia löytyy yhtäältä tietojen keruusta, aineistojen edustavuudessa että analyysin pätevyydestä. Esimerkiksi, usein taloudellista syistä, tiedonkeruu tehdään internet-paneelissa liian pienellä otoksella, jotta eri vastaajaryhmien vertailu olisi pätevää. Pahimmillaan ei edes käytetä sinänsä asianmukaista paneelia, vaan vastaajiksi valikoituu käytännössä kuka tahansa, jolloin analyysi yleistää tulokset koskemaan "suomalaisia" tai suppeammin "suomalaisia johtajia” tai "nuoria”.

\section{Todistevetoinen maineen rakentaminen}

On oleellista ymmärtää, ettei maineenkaan mittaaminen ole itseisarvo. Maineen analyysin antama tieto ja ymmärrys on integroitava käytännön johtamiseen. Kun organisaatio ymmärtää, mitä esimerkiksi eri sidosryhmät organisaatiosta ajattelevat, miten organisaation maineen eri osa-alueet painottuvat eri sidosryhmissä (Aula, 2011) tai mitkä ovat maineen heikot alueet, voi organisaatio allokoida usein erittäin rajalliset resurssinsa sinne, missä ne tekevät parasta tulosta suhteessa tavoitteisiin. Tällä on erityistä merkitystä organisaatioiden viestinnälle, sillä näin viestintä saa aikaan oikeansuuntaisia vaikutuksia, mikä osaltaan voisi vahvistaa viestintäfunktiota organisaation strategisena resurssina (Heinonen, 2008).

Maineeseen liittyvien päätösten tulisi olla osa organisaation johtamista ja pe- rustua todistevetoiseen, tutkimus-analyysipohjaiseen tietoon. Mutta mainetiedon hyödynnettävyyteen liittyvät aina päätöksentekijän tulkinta- ja harkintakyvyt. Erityistä merkitystä tällä on siksi, että hyvän tiedon saatavuuden lisäksi tarjolla on aina moninkertainen määrä tutkimustiedoksi verhottua disinformaatiota, jolla ei ole mitään arvoa. Johtamisen näkökulmasta tutkittuna tietona myyty disinformaatio voi olla vahingollista ja johtaa sekä johtajan että johtamansa yhteisön harhaan. Johtamisen keskeinen kyvykkyys onkin pätevän tiedon erottaminen epäpätevästä samalla tavalla kuin hyvän argumentoinnin erottaminen huonosta, hyvän journalismin tunnistaminen valeuutisista ja merkityksellisen viestinnän erottaminen merkityksettömästä.

Olennainen osa maineenhallintaa ja mainejohtamista on päättäjän kyky analysoida ja vaatia todistevetoista argumentointia ja päteviä aineistoja. Yhtä viisasta on huomioida, että tunteet vaikuttavat päätöksentekoon aina. Päätöksentekijän pitää osata tunnistaa tunteiden merkitys, niiden synty ja keinot vaikuttaa. Mittarien ja analyysien tuottamat todisteet yhdessä tunteiden kanssa luovat kokonaisvaltaisen ymmärryksen, jonka pohjalta onnistuneita päätöksiä tehdään.

\section{Mittaamisen haasteet}

Viestinnän ja median digitalisoitumisen ja somedialisaatiokehityksen kiihtymisen myötä organisaatioiden maineen rakentaminen kohtaa ajassamme paljon haasteita. Digitalisaatio kiihdyttää maineen muutosprosesseja (ks. Aula \& Mantere, 2013) ja 
samaan aikaan siirtymät organisaatioiden poliittisessa, sosiaalisessa ja taloudellisessa ympäristössä pakottavat organisaatiot keskittymään maineensa huoltamiseen ja puolustamiseen (Aula, 2016).

Organisaatiomaineen kannalta somedialisaatio tarjoaa uusia mahdollisuuksia. Internet-ympäristö ja sosiaalinen media on pääsy uudenlaiseen dataan, käyttäytymisen seurantaan tai julkisuuden analyysiin. Valtavan isojen data-aineistojen eli niin sanotun big datan hyödyntäminen maineen mittaamisessa ja maineanalyyseissä on vielä alkutekijöissään. Toistaiseksi sosiaalinen media on houkuttelevuudessaan luonut maineen mittaamiseen uuden paradoksin: suunnattomat määrälliset mahdollisuudet ovat tehneet maineanalysoinnista laadullisesti heikkotasoista. On osoitettavissa, että käytettävissä olevat mittarit ovat alkaneet määrittää mitattavaa ilmiöitä itseään. Kun esimerkiksi sosiaalisessa mediassa on helppoa mitata klikkausten määriä, on klikkausten määrästä tullut yksi hyvän maineen rakenneosa. Koska on vaivatonta rekisteröidä Facebookin tykkäyksiä ja päivityksen jakomääriä, todetaan, että maine rakentuu "tykkäämisestä" ja "jakamisesta”, joita juuri nämä helpot indikaattorit mittaavat. Häntä on siis alkanut heiluttaa koiraa. Tämä on paitsi epäpätevää päättelyä ja huonoa analyysia, myös organisaation päätöksenteon ja kehittymisen kannalta vahingollista. Näyttäisikin siltä, että online-ympäristön ja etunenässä sosiaalisen median vaikutus maineeseen esitetään ensisijaisesti ennalta määrätyistä ja omia tarkoitusperiä ajavista lähtökohdista eikä aineistojen ja todisteiden kautta perustel- len. Toisin sanoen yhteys sosiaalisen median merkityksestä organisaation maineelle konstruoidaan sen sijaan, että se aineiston ja argumentoinnin kautta osoitettaisiin (ks. Gond, \& Palazzo, 2008).

Suuri haaste on, että valtaosa vallitsevista maineen mittareista ja analytiikasta analysoi menneisyyttä. Survey-ylivalta on opettanut meidät katsomaan taaksepäin ja luulemaan, että vain se on merkityksellistä. Menetelmät, kuten esimerkiksi maineen kyselytutkimukset, mittaavat aina mennyttä aikaa, jotain miten joku asia on ollut. Nopeasti muuttuvissa olosuhteissa oleellista ja käyttökelpoista olisi kuitenkin katsoa eteenpäin, kehittää ja käyttää maineen mittareita, jotka pyrkivät ennakoimaan maineeseen kohdistuvia muutospaineita. Hyvä alku olisi, jos maineeseen liittyviä päätöksiä tekevät olisivat ajan tasalla organisaation maineensa tilasta reaaliajassa, mikä nykytietämyksellä ja analyysiteknologialla olisi aivan mahdollista. Erityisesti menestyksekäs maineriskien hallinta edellyttää aikaisen varoituksen menetelmiä ja dynaamista analytiikkaa, jotta riskisignaalit voidaan tunnistaa tarpeeksi ajoissa.

Kolmas haaste liittyy tyypilliseen epäselvyyteen muutoksesta. Mainetutkimuksissakin kerrotaan usein asioiden muuttuneen. Maineen rakentamisen ja johtamisen näkökulmasta tärkeää on maineen muutokseen liittyvien pitkän aikavälin trendien tunnistaminen. Oleellista on ymmärtää, mikä on maineessa tapahtuvaa kausittaista tai mittausmenetelmästä johtuvaa vaihtelua ja mikä aitoa, todellista muutosta. 
Tutkimuksen tilaajan kannalta asialla on erityistä merkitystä. Tilaaja haluaa tietää, ovatko tutkittavat asiat muuttuneet ja jos ovat, kuinka paljon ja mihin suuntaan. Harmillista kyllä, monesti muutoksesta puhutaan, vaikka mitkään edes tutkimuksessa läsnä olevat todisteet eivät tue muutoksen tapahtuneen. Muutos ja vaihtelu menevät sekaisin. Mainetutkimuksen näkökulmasta maineen vaihtelu pitkällä aikavälillä ei välttämättä tarkoita sitä, että maine on muuttunut. Mikäli muutosta havaitaan, tarvitaan todisteita, mihin monet selvitykset eivät taivu. Todisteiden on tultava tutkimuksesta itsestään, ja erityisesti tutkimuksen toteuttajalta. Toisin sanoen, todistamisen taakka on tuottajalla, ei tilaajalla.

\section{Lopuksi}

Digitaalinen aikakausi ja siihen liittyvä somedialisaatio on tehnyt maineen rakentamisen prosesseista yksityiskohtaisempia, monimutkaisempia ja merkityksellisempiä kuin koskaan aiemmin. Erityisesti avoimet verkkoympäristöt ovat luoneet tarpeen uusille ja valtavirralle vaihtoehtoisille maineen arviointi- ja analyysimenetelmille (Laaksonen et al., 2012). Organisaatioiden maineeseen ja koko käytännön viestintäkenttää koskevaan, mittaamiseen ja arviointiin liittyvään keskusteluun pitäisi saada enemmän selkeitä ja perusteltuja pätevään aineistoon perustuvia väitteitä.

Erityistä taitavuutta vaaditaan pohdittaessa maineen, viestinnän ja uuden viestintäympäristön välisiä vaikuttavuussuhteita ilman vahvoja ideologisia alkuoletuksia siitä, miten organisaatioiden tulisi toimia. Tämä on erityisen tärkeää, sillä jos väitteet ladataan lähtökohtaisesti vahvasti ideologisiksi, erilaisten selvitysten johtopäätökset ja pahimmassa tapauksessa organisaatioille tehtävät suositukset heijastavat ainoastaan valittua ideologiaa. Tällöin johtopäätökset hyväksyvät ainoastaan ne, jotka hyväksyvät taustalla olevan ideologian, ja mitään rakentavaa keskustelua ei saada aikaan. Tämä on siinä mielessä ymmärrettävää, että luotettavien aineistojen kerääminen ja analysointi on työlästä, kun taas "näin yritysten pitäisi toimia" -tyyppisten mielipiteiden esittäminen onnistuu keneltä tahansa. Ollakseen organisaatioille hyödyllistä ja tuottava investointi, maineen mittaamisessa tarvitaan enemmän pätevää ja puolueetonta analyysia ja siihen perustuvia väitteitä

\section{LÄHTEET}

Ampuja, M., Koivisto, J. \& Väliverronen, E. (2014). Medioituminen: iskusana, analyyttinen työkalu vai uusi paradigma? Media \& viestintä 37(2014), 2, 22-37.

Aula, P. (2011). Meshworked reputation: Publicists' views on the reputational impacts of online communication. Public Relations Review $37(1), 28-36$.

Aula, P. (2016). Reputation Change. Teoksessa Caroll, C. (toim.) The SAGE Encyclopedia of Corporate Reputation. Sage. 
Aula, P. (2016). Reputation and neuroscience. Teoksessa Caroll, C. (toim.) The SAGE Encyclopedia of Corporate Reputation. Sage.

Aula P. \& Heinonen, J. (2016). The Reputable Firm: How Digitalization of Communication Is Revolutionizing Reputation Management. Springer.

Aula, P. \& Mantere, S. (2013). Making and Breaking Sense: An Inquiry into the Reputation change. Journal of Organizational Change Management 26(2), 340-352.

Barnett, M. L., Jermier, J. M. \& Lafferty, B. A. (2006). Corporate reputation: The definitional landscape. Corporate Reputation Review 9(1), 26-38.

Brown, T. J. \& Dacin, P. A. (1997). The Company and the Product: Corporate Associations and Consumer Product Responses. The Journal of Marketing 61(1), 68-84.

Carroll, C. (2016). Research methods in corporate reputation. Teoksessa Caroll, C. (toim.) The SAGE Encyclopedia of Corporate Reputation. Sage.

Chun, R. (2005). Corporate reputation: Meaning and measurement. International Journal of Management Reviews 7(2), 91-109.

Eberl, M. (2006). Unternehmensreputation und Kaufverhalten. Wiesbaden: DUV.

Flanagan, D. J. \& O'Shaughnessy, K. C. (2005). The effect of layoffs on firm reputation. Journal of management 31(3), 445-463.
Fombrun, C. J. (1996). Reputation. Boston: Harvard Business School Press Boston.

Genasi, C. (2001). Measuring reputation. Teoksessa Jolly, A. (toim.) Managing Corporate Reputations. London: Kogan Page, 27-34.

Gond, J.-P. \& G. Palazzo (2008). The social construction of the positive link between corporate social responsibility and financial performance. Academy of Management Best Paper Proceedings 2008(1), 1-6.

Heinonen, J. (2008). Maineenhallinta: organisaatioviestinnän strateginen mahdollisuus. Teoksessa Aula, P. (toim.) Kivi vai katedraali. Organisaatioviestintä teoriasta käytäntöön. Infor, Porvoo.

Hutton, J. G., Goodman, M. B., Alexander, J. B. \& Genest, C. M. (2001). Reputation management. The new face of corporate public relations? Public Relations Review 27(3), 247-261.

Laaksonen, S.-M., Salminen, M., Falco, A., Aula, P. \& Ravaja, N. (2013). Use of psychophysiological measurements in communication research. Teachings from two studies of corporate reputation. ESSACHESS Journal for Communication Studies, 6(1), 245-255.

Murray, K. (2003). Reputation. Managing the single greatest risk facing business today. Journal of Communication Management 8(2), 142-149. 
Pfarrer, M. D., Pollock, T. G. \& Rindova, V. P. (2010). A tale of two assets. The effects of firm reputation and celebrity on earnings surprises and investors' reactions. The Academy of Management Journal (AMJ) 53(5), 1131-1152.

Ravaja, N., Aula, P., Falco, A., Laaksonen, S.-M., Salminen, M. \& Ainamo, A. (2015). Online news and corporate reputation: A neurophysiological investigation. Journal of Media Psychology, 27(3), 118-133.

Rayner, J. (2003). Managing reputational risk. London: JohnWiley and Sons.

Renner, M. (2011). Generating Trust via Corporate Reputation. Berlin: WVB.

Rhee, M. \& Valdez, M. (2009). Contextual Factors Surrounding Reputation Damage with Potential Implications for Reputation Repair. The Academy of Management Review ARCHIVE 34(1), 146-168.

Rindova, V. P., Pollock, T. G. \& Hayward, M. L. (2006). Celebrity firms: The social construction of market popularity. Academy of Management Review 31(1), 50-71. 


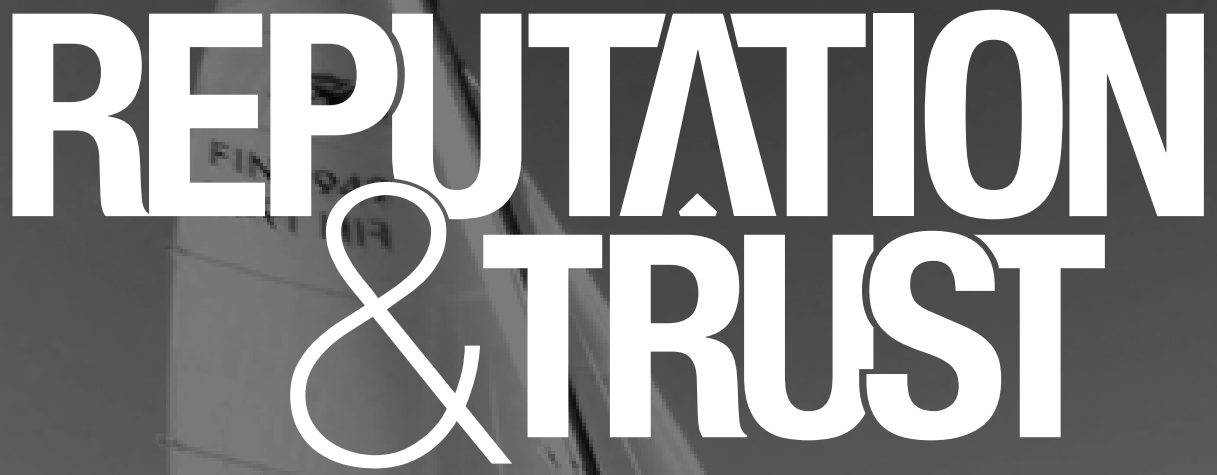

\section{A i 0 उ M \\ TMEDIA}

8

\section{F18}

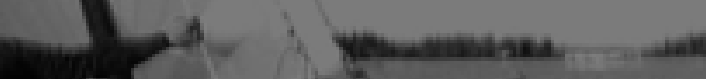

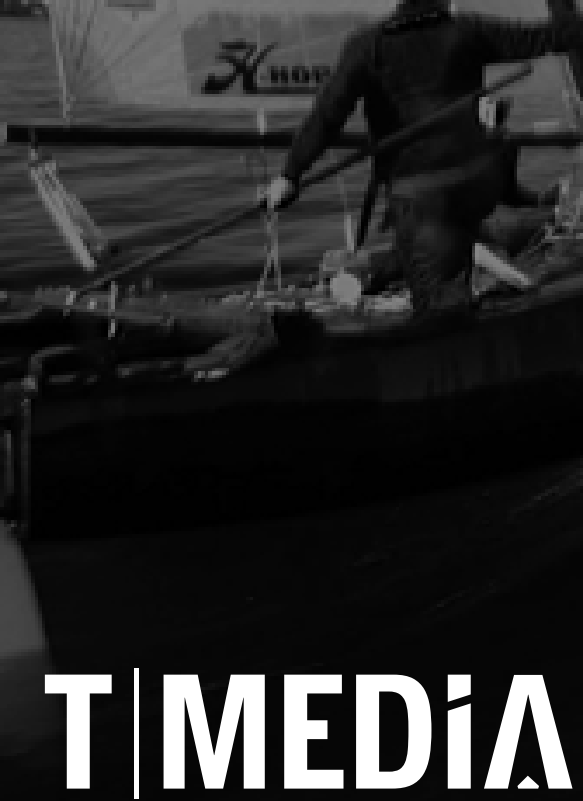

RESEARCH BASED REPUTATION ADVISORY

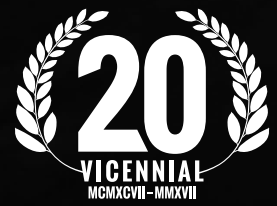




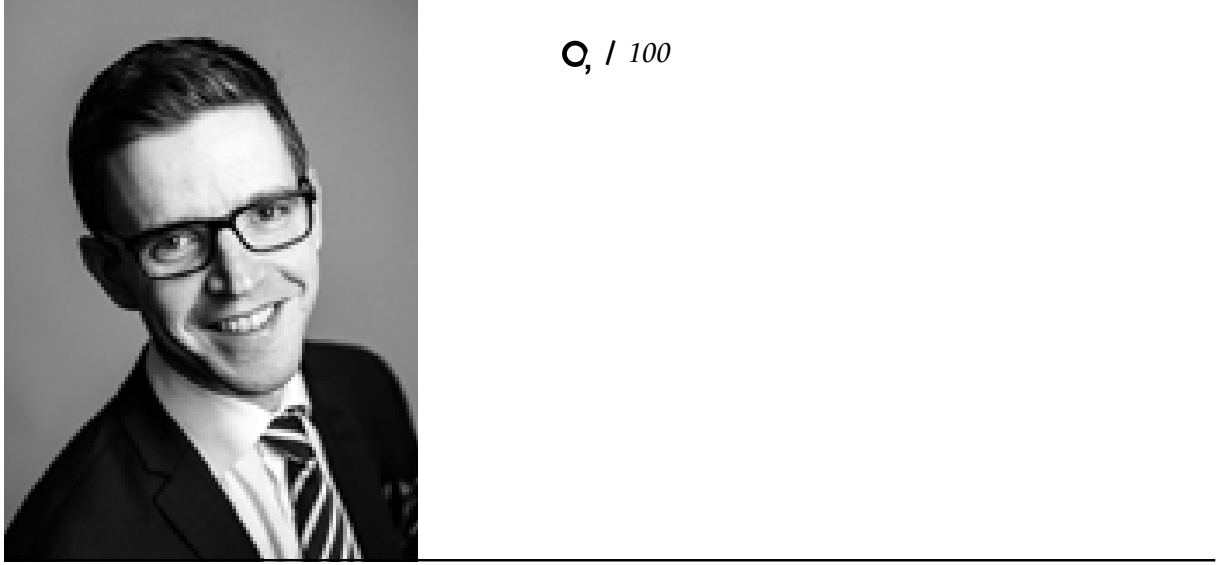

KUKA?

Hannu Saarijärvi

- Kauppatieteen tohtori Hannu

Saarijärvi on palvelujen ja kaupan

professori Tampereen yliopistossa.

Hänen tutkimusalueitaan ovat $\mathrm{mm}$.

asiakkaan kokema arvo, asiakastieto

ja asiakkuudet, strateginen markki-

nointi sekä palvelualojen murros,

yhteiskunnallinen rooli ja potentiaali.

MITEN VIESTIÄ JA MITATA ASIAKASLÄHTÖISYYTTÄ?

$K$

äsitevalinnat heijastavat maailmankuvaamme. Talous talouspolitiikka ja poliittinen retoriikka - on keskeinen maailmankuvaa muokkaava mekanismi. Viestinnän rooli tämän maailmankuvan ja siihen liittyvän dynamiikan analysoimisessa ja välittämisessä on kriittisen tärkeä. Sekä globaali että kansallinen talous rakentuu vaihdannalle: yritykset ja kuluttajat maksavat rahaa tuotteista ja palveluista, joita tarvitsevat. Tämän vuoksi kaiken taloudellisen toimeliaisuuden lähtökohtana ovat erilaisten asiakkaiden erilaiset tarpeet ja niiden syvällinen ymmärtäminen. Asiakaslähtöisyydestä viestiminen on kuitenkin 
haastavaa, sillä sen käsitteistö ja mittaristo ovat kehittymättömiä eivätkä ne kytkeydy kiinteästi yhteiskunnalliseen keskusteluun.

Tämä artikkeli rakentaa viestinnän ammattilaisille käsitteellisen viitekehyksen, jolla ymmärtää, arvioida ja mitata asiakaslähtöisyyttä. Viitekehys parantaa edellytyksiä viestiä asiakaslähtöisyyden yhteiskunnallisesta roolista ja merkityksestä. Tutkimustavoitteeseen vastataan kolmivaiheisesti. Ensiksi, johdantoluvussa käsitellään lyhyesti asiakaslähtöisyyden roolia talouspoliittisessa keskustelussa ja liiketaloustieteellisessä tutkimuksessa. Toiseksi, olemassa olevaa kirjallisuutta hyödyntäen rakennetaan käsitteellinen viitekehys, joka tunnistaa ja analysoi asiakaslähtöisyyden keskeiset käsitteet ja mittarit. Kolmanneksi, artikkelin yhteenvetoluku tiivistää keskeisimmät havainnot ja jatkotutkimusmahdollisuudet.

\section{Johdanto: mitä on asiakaslähtöisyys?}

Asiakaslähtöisyys siirtää yrityksen toiminnan lähtökohdaksi asiakkaan. Asiakaslähtöiselle organisaatiolle keskeinen kysymys on se, miten sen tuotteet, palvelut, resurssit ja prosessit tarjoutuvat asiakkaalle sekä miten ja millaista arvoa asiakas niiden avulla lopulta luo. Asiakaslähtöisyyden avulla syvennytään asiakkaan kokemaan arvoon ja siihen, mitä asiakkaat lopulta arvostavat ja mikä on heille merkityksellistä tuotteiden ja palvelujen kuluttamisessa. Tämä vaikuttaa asiakkaiden haluun mak- saa ja jatkaa yritysten asiakkaana myös jatkossa. Tämän vuoksi asiakaslähtöisyys on keskeinen yhteiskunnallinen käsite: se kytkeytyy tuotettuun arvonlisään ja tuottavuuteen. Bruttokansantuotettakin määrittää pitkällä aikavälillä lopulta kansallinen kyky mukautua kotimaisten ja kansainvälisten asiakastarpeiden muutoksiin. Asiakaslähtöisyys, joka on käsitteellisesti hyvin lähellä myös palvelumuotoilun (service design) teemoja, on noussut viimeisten vuosien aikana myös tärkeäksi yritysten ja julkisten organisaatioiden kehittämistä ohjaavaksi ajuriksi.

Talouspoliittisessa keskustelussa asiakaslähtöisyyden merkitys on jäänyt kuitenkin viestinnälliseen marginaaliin. Keskustelua hallitsevat yritysten ja yhteiskunnan näkökulmat. Yritysnäkökulmalle on tyypillistä keskustelu innovaatioiden tuottamisesta ja yritysten toimintaedellytysten parantamisesta: yritysten pitäisi pystyä tuottamaan alhaisimmilla kustannuksilla nykyistä enemmän sellaisia uusia tuotteita ja palveluja, joille löytyisi maailmalta kysyntää. Yhteiskunnalliselle näkökulmalle on vastaavasti ominaista makrotaloustieteellinen käsitteistö, joka korostaa mm. työllisyyskehitystä ja vientipotentiaalia keskeisinä yhteiskunnan toimintaedellytysten turvaajina.

Sekä yritysten että yhteiskunnan näkökulmat ovat relevantteja ja perusteltuja analysoitaessa kansantalouden toimintaa. Viestinnällisesti ne eivät kuitenkaan käsittele taloudellisen dynamiikan syvintä olemusta: asiakastarpeita. Vaihdannan lähtökohtana olevat asiakastarpeet - joko kansalliset tai kansainväliset - määrittävät 
ensisijaisesti sekä yritys- että yhteiskunnallisia näkökulmia. Yritysnäkökulma on alisteinen asiakastarpeille: yritykset lunastavat olemassaolonsa oikeutuksen vain asiakkaidensa kautta. Nykyinen yhteiskunnallisen keskustelun käsitteistö eriyttää keskustelun taloudellisen toimeliaisuuden ytimestä: kysynnän syvällisestä ymmärryk- sestä sekä yritysten ja julkisten organisaatioiden kyvystä vastata siihen. Yhteiskunnallinen keskustelu tarvitsee kollektiivista keskustelun painopisteen laajentamista yritys- ja yhteiskunnallisesta näkökulmasta asiakaslähtöisyyteen: asiakastarpeiden ymmärtämiseen, arvioimiseen ja mittaamiseen (Kuvio 1).

Kuvio 1. Talouspoliittisen viestinnän näkökulmat

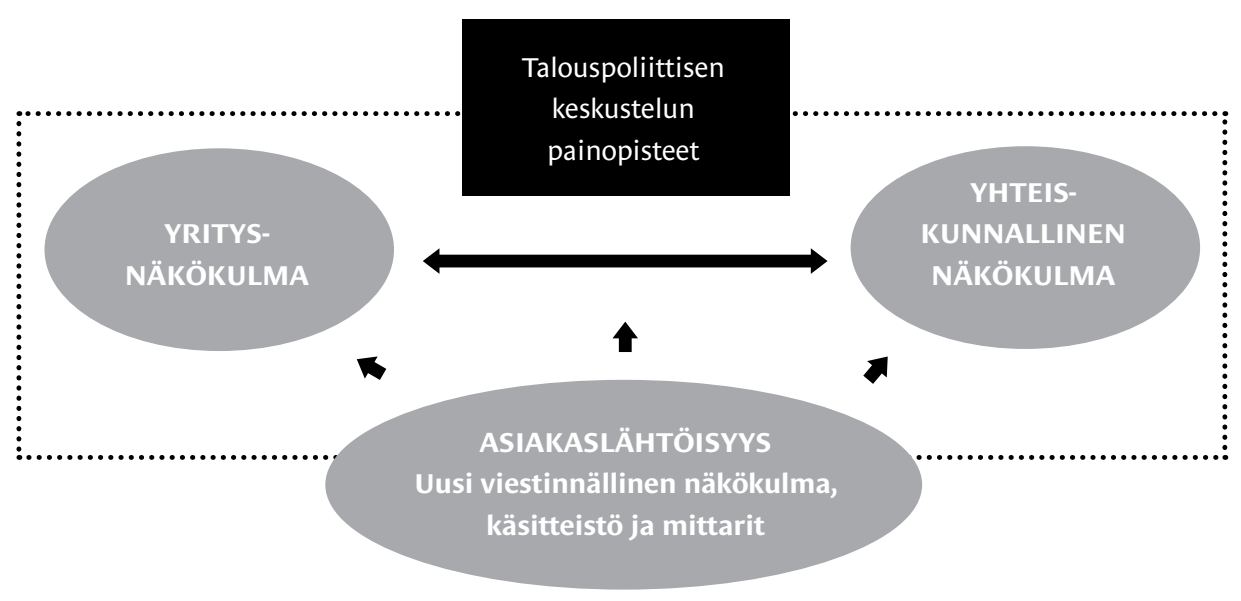


Vaikka talouspoliittinen keskustelu vierastaa asiakaslähtöisyyttä, tutkimuskirjallisuudessa se on korostunut erityisesti 2000-luvulla. Asiakaslähtöisyyttä korostavat tutkimussuuntaukset ovat haastaneet perinteistä kansantaloustieteellistä ja tuotantolähtöistä tutkimusta, jotka ovat osaltaan vaikuttaneet keskeisten liiketalouden käsitteiden käyttämiseen: tuote, palvelu, arvonlisä, vaihdanta tai arvoketju ovat lähtökohtaisesti hyvin tuotantolähtöisiä käsitteitä ja tarkastelevat taloutta yritysten näkökulmasta. Ne korostavat tuotteiden ja palvelujen tuottamiseen liittyviä ominaispiirteitä kuten yksikkökustannuksia, varaston kiertonopeutta tai tuotantokatetta. Vaikka nämä ovat tärkeitä teemoja, ne eivät jäsennä talouden ilmiöitä asiakastarpeiden näkökulmasta. Tuotantolähtöisyys voikin heijastua myös päätöksentekijöiden ajattelua ohjaaviin mentaalimalleihin (ks. Birshan et al., 2014; Strandvik et al., 2014) ja sitä kautta heidän käyttämäänsä retoriikkaan.

Viimeisten kahden vuosikymmenen aikana tuotantolähtöistä käsitteistöä on alettu vahvasti kritisoida. Tämän seurauksena 2000-luvulla on syntynyt tutkimussuuntauksia - tai jopa koulukuntia - jotka korostavat asiakaslähtöisyyttä kaiken taloudellisen vaihdannan perustana. Ns. service-dominant logic (Vargo \& Lusch, 2004, 2008, 2011), service logic (Grönroos 2008a, 2008b) tai customer-dominant logic (Heinonen et al., 2010; Strandvik, Holmlund \& Edvardsson, 2008) siirtävät kollektiivisesti huomiota yrityksen kontekstista asiakkaan kontekstiin. Käytännössä tämä tarkoittaa esimerkiksi ruokakaupan roolin muuttumista elintarvikkeiden myyjästä kuluttajien ruokaan liittyvien arkisten käytäntöjen ja prosessien tukijaksi: esimerkiksi asiakastietoa hyödyntämällä kuluttajille tarjotaan ruoan terveellisyyteen liittyvää informaatiota, resepti-ideoita aiempaan ostokäyttäytymiseen perustuen tai gluteenittomia ruokavaihtoehtoja allergikoille. Tämä edellyttää sekä syvää ymmärrystä asiakastarpeista ja huomion siirtämistä tuotteista asiakkaaseen että uudenlaisten mittareiden kehittämistä: asiakkaiden keskittämisaste, suositteluhalukkuus sekä asiakastyytyväisyys ja -uskollisuus ovat esimerkkejä keskeisistä mittareista.

Tutkimussuuntausten ohella asiakaslähtöisyyttä kuvaava käsitteistö on kehittynyt. Viimeisten vuosikymmenien aikana liiketaloustieteellisessä tutkimuksessa on kehitetty monia erilaisia käsitteitä kuvaamaan organisaatioiden ja asiakkaiden välistä dynamiikkaa erityisesti asiakkaan näkökulmasta. Käsitteet kuten asiakasarvo (esim. Khalifa, 2004; Rintamäki, Kuusela \& Mitronen, 2007); asiakaslupaus (esim. Anderson, Narus \& van Rossum, 2006), asiakassuhde (esim. Morgan \& Hunt, 1994), asiakasorientaatio (esim. Narver \& Slater 1990; Kohli \& Jaworski 1990), asiakaspolku (esim. Lemon \& Verhoef, 2016), arvon yhteisluominen (esim. Vargo \& Lusch, 2008; Saarijärvi, Kannan \& Kuusela, 2013), asiakkuuksien johtaminen (esim. Boulding, Staelin, Ehret, \& Johnston, 2005), asiakaskokemus (esim. Verhoef et al., 2009), asiakastieto (esim. Saarijärvi, Karjaluoto \& Kuusela, 2013) ja asiakasymmärrys (esim. Blosch, 2000) ovat nousseet tärkeiksi asiakaslähtöisyyttä konkretisoi- 
viksi käsitteellisiksi työkaluiksi.

Nämä käsitteet ovat siirtäneet alkujaan hyvinkin tuotantolähtöistä liiketalous- ja markkinointitieteellistä oppia (ks. Vargo \& Lusch, 2004) enemmän kohti vaihdannan fundamentaalista lähtökohtaa eli asiakastarpeita. Monet asiakaslähtöisyyttä korostavat käsitteet on myös empiirisesti osoitettu selittävän yrityksen menestymisen ja olemassaolon kannalta keskeisiä mittareita kuten asiakasuskollisuutta, asiakastyytyväisyyttä ja suosittelua.

\section{Asiakaslähtöisyyden keskeiset käsitteet ja mittarit}

Viimeisen 10 vuoden kuluessa asiakaslähtöisyyttä konkretisoivista käsitteistä asiakaslupaus, asiakasarvo ja asiakaskokemus ovat nousseet sekä tutkimuksellisesti että käytännön liiketoiminnan näkökulmasta siteeratuiksi, sovelletuiksi ja suosituiksi tavoiksi tutkia ja johtaa sekä viestiä liiketoimintaa. Lisäksi asiakaslähtöisyyden keskeiset mittarit - asiakastyytyväisyys, suosittelu ja asiakasuskollisuus - ovat tärkeitä täydentäviä käsitteitä, sillä ne sitovat kyvyn vastata asiakastarpeisiin yrityksen menestymisen mittareihin. Kokonaisuutena nämä käsitteet auttavat määrittämään asiakaslähtöisyyden merkitystä yritysnäkökulman ja yhteiskunnallisen näkökulman välissä (Kuvio 2 seuraavalla sivulla). Lisäksi ne luovat relevantin käsitteellisen viitekehyksen ymmärtää, arvioida ja mitata asiakaslähtöisyyden yhteiskunnallista roolia.

\section{Asiakaslupaus}

Asiakaslupaus on verbaalinen kuvaus, slogan tai brändiviesti siitä arvosta, jota yritys pyrkii asiakkaille luomaan (Anderson, Narus \& van Rossum, 2006; Webster, 1992). Asiakaslupauksella on kaksi tehtävää. Ensinnäkin, asiakaslupaus asemoi yrityksen ulkoisesti markkinoilla tapahtuvaan kilpailuun. Painottamalla asiakaslupauksessaan esimerkiksi hintaa, palvelutasoa, brändiin liitettyjä mielikuvia tai korkeaa laatua yritys erilaistuu muista. Tämä edellyttää ymmärrystä ns. kilpailukykytekijöistä (points of parity) ja kilpailuetutekijöistä (points of difference) (Anderson, Narus ja van Rossum, 2006). Asiakaslupauksen avulla yritykset hakevat paikkansa markkinoilla ja samalla luovat asiakkaalle odotustason hänelle luotavasta arvosta. Toiseksi, asiakaslupaus on sisäinen johtamisen työkalu, sillä se kytkee asiakaslupauksen sisällön (esim. erilaistuminen halvimmilla hinnoilla) yrityksen prosesseihin ja osaamisiin (esim. toimitusketjun hallinta, hinnoittelustrategiat, valikoimahallinta). Esimerkiksi K-Supermarketin "Tavallista parempi ruokakauppa" sekä viestii kuluttajille ruokakaupan fokusoitumisesta korkeaan laatuun että asettaa samalla tavoitetason henkilöstölle. Asiakaslupaus määrittääkin yrityksen punaisen langan: se yhtenäistää yrityksen toiminnan asiakaslupauksen toteuttamiseksi (Rintamäki, Kuusela \& Mitronen, 2007).

\section{Asiakasarvo}

Asiakasarvo on seuraus asiakkaan kokemista hyödyistä ja uhrauksista, ja se selittää asiakkaan osto- ja kulutuskäyttäytymistä (Rintamäki, Kuusela \& Mitronen, 2007). Asiakasarvo voidaan jakaa neljään asiakasarvon ulottuvuuteen: taloudelli- 

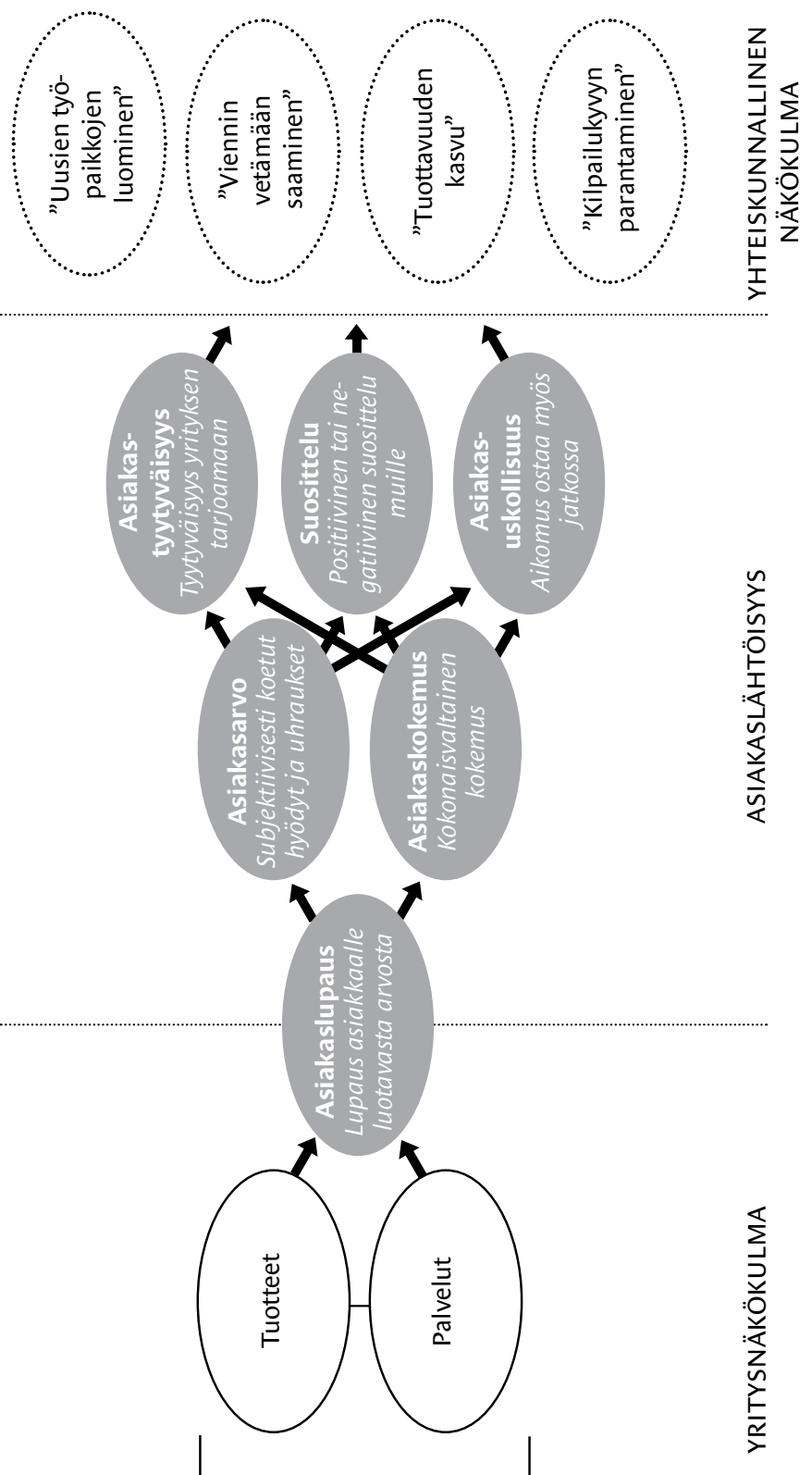

Yrityksen tarjoama asiakastarpeisiin 
seen arvoon (fokus rahan säästämisessä), toiminnalliseen asiakasarvoon (fokus vaivattomuudessa, ajan ja vaivan minimoimisessa), emotionaaliseen asiakasarvoon (fokus kokemuksessa ja mielihyvässä) ja symboliseen asiakasarvoon (fokus positiivisissa merkityksissä). Näistä kaksi ensimmäistä ulottuvuutta ovat luonteeltaan utilitaristisia ja kaksi jälkimmäistä hedonistisia (Rintamäki, 2016). Esimerkiksi Lidlin toiminta perustuu vahvasti taloudellisen asiakasarvon luomiseen, kun Stockmann korostaa emotionaalista ja symbolista asiakasarvoa.

Asiakasarvon ja asiakaslupauksen käsitepari kuvaavat samaa ilmiötä - asiakastarpeita ja organisaatioiden kykyä vastata näihin tarpeisiin - toisiaan täydentävistä näkökulmista. Siinä missä asiakaslupaus kuvaa yrityksen tavoitetta asiakkaalle luotavasta arvosta, asiakasarvo heijastaa tosiasiallista asiakkaan kokemaa arvoa, joka syntyy kun asiakas käyttää yrityksen tarjoamaa (tuotteet ja palvelut).

\section{Asiakaskokemus}

Asiakaskokemus laajentaa huomion yrityksen tuotteista ja palveluista asiakkaan kokonaisvaltaiseen kokemukseen. Verhoef et al. (2009) korostaa laajasti siteeratussa määritelmässään, että asiakaskokemus sisältää asiakkaan kognitiivisen, affektiivisen, emotionaalisen ja fyysisen kokemuksen yrityksen tarjoamasta. Asiakaskokemus kumuloituu ajan kuluessa. Se syntyy ja kehittyy ostoprosessin kaikissa vaiheissa (vertailu, ostopäätös, kulutus) ja kaikissa kanavissa (esim. fyysiset kanavat vs. digitaaliset kanavat) (Verhoef et al.,
2009). Tämän vuoksi esimerkiksi lääkäripalveluja tarjoavan yrityksen asiakaskokemukseen vaikuttaa itse lääkärissä käynnin lisäksi yrityksen internet-sivujen tarjoama informaatio, ajanvarauksen helppous ja vaivattomuus, asiakaspalvelun ystävällisyys, odotustilojen viihtyisyys sekä esimerkiksi resepteihin tai sairauspoissaoloihin liittyvän dokumentaation selkeys ja helppous. Asiakaskokemukseen voivat vaikuttaa myös tekijät, joihin yritys ei aina voi vaikuttaa, kuten toisten asiakkaiden läsnäolo ja heidän toimintansa elokuvateatterissa tai ravintolassa.

\section{Asiakastyytyväisyys, suosittelu ja asiakasuskollisuus}

Asiakkaiden tyytyväisyys, suositteluhalukkuus ja uskollisuus ovat perinteisiä ja tutkimuskirjallisuudessa laajalti sovellettuja seuraustason mittareita, joilla mitataan, kuinka hyvin yrityksen tarjoama on onnistunut vastaamaan asiakastarpeisiin. Empiirisissä tutkimusasetelmissa esimerkiksi yritysten markkinointitoimenpiteiden vaikuttavuutta, uusien palvelujen kehittämistä tai investointeja asiakaspalvelun laatuun pyritään mittaamaan juuri asiakastyytyväisyyden, suosittelun ja asiakasuskollisuuden kautta. Viimeisten vuosien aikana seuraustason mittareita on pyritty yksinkertaistamaan, minkä seurauksena myös ns. NPS-mittarin (net promoter score) käyttö on yleistynyt. NPS mittaa, kuinka todennäköisesti asiakas suosittelisi yrityksen tuotteita ja palveluja ystävilleen tai muille läheisilleen. 
Taulukko 1. Asiakasnäkökulman keskeiset käsitteet

\begin{tabular}{|c|c|c|}
\hline Käsite & Kuvaus & Mittareita viestinnälle \\
\hline Asiakaslupaus & $\begin{array}{l}\text { Yrityksen lupaus asiakkaalle luota- } \\
\text { vasta arvosta tai hyödystä. Käyte- } \\
\text { tään usein brändisloganina osana } \\
\text { markkinointiviestintää. Ohjaa } \\
\text { myös yrityksen sisäistä toimintaa: } \\
\text { strategisia painopistealueita, ydin- } \\
\text { prosesseja ja osaamisvaatimuksia. }\end{array}$ & $\begin{array}{l}\text { Kvalitatiivinen sisällönanalyysi yri- } \\
\text { tysten asiakaslupauksista. Millaiset } \\
\text { hyödyt (taloudelliset, toiminnalliset, } \\
\text { emotionaaliset, symboliset) ovat } \\
\text { asiakaslupauksen keskiössä? }\end{array}$ \\
\hline Asiakasarvo & $\begin{array}{l}\text { Asiakkaan kokema arvo. Määritel- } \\
\text { lään asiakkaan kokemien hyötyjen } \\
\text { (esim. laatu, nopeus, vaivattomuus) } \\
\text { ja uhrausten (esim. raha, vaiva, } \\
\text { stressi) erotuksena. }\end{array}$ & $\begin{array}{l}\text { Väittämäpohjaiset mittarit taloudel- } \\
\text { liselle, toiminnalliselle, emotionaali- } \\
\text { selle ja symboliselle arvolle. Lisäksi } \\
\text { kvalitatiivinen sisällönanalyysi aut- } \\
\text { taa erittelemään arvon ulottuvuuk- } \\
\text { sia. Sovellettavia mittaristoja esim. } \\
\text { Rintamäki et al. (2006), Rintamäki } \\
\text { \& Kirves (2016). }\end{array}$ \\
\hline Asiakaskokemus & $\begin{array}{l}\text { Asiakkaan kokema kokonaisvaltai- } \\
\text { nen kokemus. Laajentaa huomiota } \\
\text { tuotteiden ja palveluiden kulutta- } \\
\text { misesta laajempaan kuluttajan ko- } \\
\text { kemukseen, joka rakentuu kaikissa } \\
\text { asiakkaan ja yrityksen vuorovaiku- } \\
\text { tus-tilanteissa ja kaikissa kanavissa. }\end{array}$ & $\begin{array}{l}\text { Väittämäpohjaiset, Likert-astei- } \\
\text { kolliset mittarit, jotka huomioivat } \\
\text { tuotteiden ja palveluiden lisäksi } \\
\text { myös esimerkiksi asiakaspalvelun } \\
\text { laadun ja palveluympäristön osana } \\
\text { asiakaskokemusta. Toimialakohtai- } \\
\text { sia eroja. Sovellettavia mittaristoja } \\
\text { esim. Verhoef et al. (2009). }\end{array}$ \\
\hline
\end{tabular}




\begin{tabular}{|c|c|c|}
\hline $\begin{array}{l}\text { Asiakas- } \\
\text { tyytyväisyys }\end{array}$ & $\begin{array}{l}\text { Asiakkaan tyytyväisyys yrityksen } \\
\text { tarjoamaan. Asiakastyytyväisyy- } \\
\text { teen vaikuttaa myös odotustaso, } \\
\text { jota määrittävät mm. aiemmat } \\
\text { kokemukset ja yrityksen markki- } \\
\text { nointiviestintä sekä mielikuvat } \\
\text { täydellisestä kokemuksesta. }\end{array}$ & $\begin{array}{l}\text { Väittämäpohjaiset, Likert-asteikol- } \\
\text { liset mittarit, jotka mittaavat } \\
\text { tyytyväisyyttä eri näkökulmista } \\
\text { (mm. odotustaso, kokemus vs. } \\
\text { kuviteltu täydellinen kokemus, } \\
\text { kokonaistyytyväisyys). Sovellettavia } \\
\text { mittaristoja esim. Mägi (2003). }\end{array}$ \\
\hline Suosittelu & $\begin{array}{l}\text { Asiakkaan suositteluhalukkuus eli } \\
\text { kuinka todennäköisesti asiakas } \\
\text { suosittelisi yrityksen tarjoamaa } \\
\text { muille (esim. sukulaisille, ystäville). } \\
\text { Sosiaalisen median aikakaudella } \\
\text { suosittelun merkitys on kasvanut } \\
\text { merkittävästi. }\end{array}$ & $\begin{array}{l}\text { Väittämäpohjaiset, Likert-asteikol- } \\
\text { liset mittarit, jotka mittaavat } \\
\text { suosittelua monella väittämällä. } \\
\text { Sovellettavia mittaristoja esim. } \\
\text { Jones et al. (2006). NPS-mittari } \\
\text { on yleistynyt yksinkertaisena ja } \\
\text { nopeana mittaamisen tapana. }\end{array}$ \\
\hline $\begin{array}{l}\text { Asiakas- } \\
\text { uskollisuus }\end{array}$ & $\begin{array}{l}\text { Asiakasuskollisuus kuvaa halua } \\
\text { ostaa tulevaisuudessa. }\end{array}$ & $\begin{array}{l}\text { Väittämäpohjaiset, Likert-asteikolli- } \\
\text { set mittarit, jotka mittaavat asiakas- } \\
\text { uskollisuutta asiointiaikomuksen, } \\
\text { uudelleen ostamisen, asiakas- } \\
\text { pysyvyyden ja keskittämis- } \\
\text { asteen näkökulmasta. Sovellettavia } \\
\text { mittaristoja esim. Seiders, Voss \& } \\
\text { Godfrey (2005). }\end{array}$ \\
\hline
\end{tabular}

Taulukko 1 tiivistää ja määrittää asiakaslähtöisyyttä konkretisoivat käsitteet ja tavat, joilla niitä voidaan mitata.

\section{Kohti vaikuttavampaa viestintää}

Käsitevalinnat heijastavat maailmankuvaamme. Maailmankuvia rakennetaan ja puretaan erilaisia käsitteitä valitsemalla ja painottamalla. Yksipuolinen käsittei- den käyttö ohjaa helposti liian kapeaan ymmärrykseen ja yhteiskunnallisen keskustelun näköalattomuuteen. Viestinnän rooli kansantaloudellisen mentaalimallin eli päätöksentekoa ohjaavien jaettujen uskomusten haastamisessa on kriittinen. Nykyisessä yhteiskunnallisessa keskustelussa painottuvat retoriset oikopolut, jotka käsittelevät pelkästään seuraustasoa 
eivätkä niiden alkujuurta. "Uusien työpaikkojen luominen", "viennin vetämään saaminen", "työpaikkojen luominen", "tuottavuuden kasvu" tai "kilpailukyvyn parantaminen" ovat seuraustason asioita eivätkä huomioi riittävästi asiakastarpeita, jolle ne kaikki ovat lopulta alisteisia. Tämän yhteiskunnallisen keskustelun sokean pisteen korjaamisessa viestinnällä on merkittävä rooli.

Syvempi ymmärrys asiakaslähtöisyydestä ja sitä kuvaavista keskeisistä käsitteistä auttavat viestinnän ammattilaisia kuvaamaan talouden dynamiikkaa relevanteimmin käsittein. Tässä artikkelissa esitellyt käsitteet ja mittarit edistävät taloudellisten ilmiöiden yhteiskunnallista analysointia sekä täydentävät talouspoliittista keskustelua. Viestinnän ammattilaisten näkökulmasta keskeistä ei ole pyrkiä hyödyntämään heti kaikkia käsitteitä ja mittareita, vaan aloittaa käyttämällä esimerkiksi asiakasarvon käsitettä tai NPS-mittaria asiakaslähtöisyyttä yritysten liiketoimintaa analysoitaessa.

Vaikka asiakaslähtöisyyttä on tutkittu syvällisesti ja laaja-alaisesti viimeisten vuosikymmenien aikana, sen integrointi yhteiskunnalliseen keskusteluun on jäänyt marginaaliseksi ja pinnalliseksi. Tutkimusta asiakaslähtöisyyden viestinnällisestä ulottuvuudesta on tehtävä nykyistä enemmän ja vaikuttavammin. Lisätutkimus palvelisi laajasti yhteiskunnallista tarvetta ymmärtää talouden dynamiikkaa ja sitä käsittelevää päätöksentekoa nykyistä syvällisemmin sekä ohjaisi yritysten ja organisaatioiden toimintakulttuuria nykyistä asiakaslähtöisempään suuntaan.

\section{Aloita näistä:}

Almquist, E., Senior, J. \& Bloch, N. (2016). The elements of value. Harvard Business Review, September. Saatavilla verkossa: https://hbr.org/2016/09/the-elements-of-value

Anderson, J. C., Narus, J. A. \& van Rossum, V. (2006). Customer value propositions in business markets. Harvard Business Review, 84(3), 91-99.

Rintamäki, T., Kuusela, H. \& Mitronen, L. (2007). Identifying competitive customer value propositions in retailing. Managing Service Quality, 17(6), 621-634.

\section{LÄHTEET}

Anderson, J. C., Narus, J. A. \& van Rossum, V. (2006). Customer value propositions in business markets. Harvard Business Review, 84(3), 91-99.

Birshan, M., Gibbs, E. \& Strovink, K. (2014). Rethingking the role of the strategist. McKinsey Quarterly, 9. Saatavilla verkossa: http://www. mckinsey.com/insights/strategy/rethinking_the_ role_of_the_strategist

Blosch, M. (2000). Customer knowledge. Knowledge and Process Management, 4(4), 265-268.

Boulding, W., Staelin, R., Ehret, M. \& Johnston, W. (2005). A customer relationship management roadmap: What is known, potential pitfalls, and where to go. Journal of Marketing, 69(4), 155-166.

Grönroos, C. (2008a). Service logic revisited: Who creates value? And who co-creates?. 


\section{O, / 110}

European Business Review, 20(4), 298-314.

Grönroos, C. (2008b). Adopting a service business logic in relational business-to-business marketing: Value creation, interaction and joint value co-creation. Esitelmä Otago Forum 2:ssa 9.-12.12.2008, Dunedin, Uusi-Seelanti.

Heinonen, K., Strandvik, T., Mickelsson, K.-J., Edvardsson, B., Sundström, E. \& Andersson, P. (2010). A customer-dominant logic of service. Journal of Service Management, 21(4), 531-548.

Jones, M.A., Reynolds, K.E. \& Arnold, M.J. (2006). Hedonic and utilitarian shopping value: Investigating differential effects on retail outcomes. Journal of Business Research, 59(9), 974-981.

Khalifa, A.S. (2004). Customer value: A review of recent literature and an integrative configuration. Management Decision, 42(5), 645-666.

Kohli, J. K. \& Jaworski, B. J. (1990). Market orientation: The construct, research propositions, and manageriali implications. Journal of Marketing 54(2), 1-18.

Lemon, K. N. \& Verhoef, P. C. (2016). Understanding customer experience throughout the customer journey. Journal of Marketing, 80(6), 69-96.

Morgan, R. \& Hunt, S.D. (1994). The commitment trust theory of relationship marketing, Journal of Marketing, 58(3), 20-38.

Mägi, A. Q. (2003). Share of wallet in retailing: The effects of customer satisfaction, loyalty cards and shopper characteristics. Journal of
Retailing, 79(2), 97-106.

Narver, J. C. \& Slater, S. F. (1990). The effect of a market orientation on business profitability. Journal of Marketing 54(4), 20-35.

Payne, A.F. \& Frow, P. (2005). A strategic framework for customer relationship management. Journal of Marketing, 69(4), 167-176.

Rintamäki, T. (2016). Managing Customer Value in Retailing. An integrative Perspective. Acta Universitatis Tamperensis 2152. Tampere University Press: Tampere 2016.

Rintamäki, T. \& Kirves, K. (tulossa). From perceptions to propositions: Profiling customer value across retail contexts. Journal of Retailing and Consumer Services.

Rintamäki, T., Kuusela, H. \& Mitronen, L. (2007). Identifying competitive customer value propositions in retailing. Managing Service Quality, 17(6), 621-634.

Saarijärvi, H., Karjaluoto, H. \& Kuusela, H. (2013). Customer relationship management: The evolving role of customer data. Marketing Intelligence and Planning, 31(6), 584-600.

Saarijärvi, H., Puustinen, P., Yrjölä, M. \& Mäenpää, K. (tulossa). Service-dominant logic and service logic - contradictory and/ or complementary?. International Journal of Services Sciences.

Seiders, K., Voss, G.B., Grewal, D. \& Godfrey, A.L. (2005). Do Satisfied Customers Buy More? Examining Moderating Influences in a Retai- 
ling Context. Journal of Marketing 69(4), 26-43.

Strandvik, T., Holmlund, M. \& Grönroos, C. (2014). The mental footprint of marketing in the boardroom. Journal of Service Management, 25(2), 241-252.

Strandvik, T., Holmlund, M. \& Edvardsson, B. (2008). Customer needing - conceptualizing industrial service from a customer perspective. Working Papers, No. 536. Helsinki, Finland: Swedish School of Economics and Business Administration.

Vargo, S. L. \& Lusch, R.F. (2004). Evolving to a new dominant logic for marketing. Journal of Marketing, 68(1), 1-17.

Vargo, S. L. \& Lusch, R. F. (2008). Service-dominant logic: Continuing the evolution. Journal of the Academy of Marketing Science, 36(2), 1-10.

Vargo, S. L., Lusch, R. F. \& Morgan, F. (2006). Historical perspective on service-dominant logic. Teoksessa Lusch, R. F., \& Vargo, S. L. (toim.) (2006). The service-dominant logic of marketing: Dialog, debate, and directions. Armonk, NY: ME Sharpe, 29-42.

Verhoef, P. C., Lemon, K. N., Parasuraman, A., Roggeveen, A., Tsiros, M. \& Schlesinger, L. A. (2009). Customer experience creation: Determinants, Dynamics and Management Strategies. Journal of Retailing, 85(1), 31-41.

Webster, F. E. (1992). The changing role of marketing in the corporation. Journal of Marketing, 58(4), 1-17.
Zablah, A. R., Bellenger, D. N. \& Johnston, W. J. (2004). An evaluation of divergent perspectives on customer relationship management: Towards a common understanding of an emerging phenomenon. Industrial Marketing Management, 33(6), 475-489. 
erityisesti siihen, miten integroitu raportointi palvelee yritysvastuun mittaamista ja arviointia sekä niistä viestintää. Luomme katsauksen sekä alan tuoreimpaan tutkimuskirjallisuuteen että yritysraportoinnin käytäntöön, ja arvioimme yritysvastuuraportoinnin tulevaisuuden kehityskohteita.

\section{Johdanto: mistä integroidussa raportoinnissa on kyse?}

Kestävä kehitys on yksi aikamme suurimpia haasteita ja aiheuttaa paineita erityisesti globaalisti vaikutusvaltaisille suuryrityksille. Monimuotoisen viestinnän tärkeys korostuu, kun yritykset pyrkivät vastaamaan niihin kohdistettuihin liiketaloudellisiin ja yhteiskunnallisiin odotuksiin. Sijoittajat odottavat tietoa yrityksen taloudellisesta tilanteesta ja tulosodotuksista, asiakkaita kiinnostavat tuotteiden laatu ja alihankintaketjujen eettisyys, työntekijät toivovat avointa, reilua ja osallistavaa päätöksentekokulttuuria, alihankkijat haluavat olla mukana kehittämässä uusia tuotteita ja toimintatapoja ja yhteiskunta odottaa yritykseltä verotuloja, mutta myös avoimuutta, läpinäkyvyyttä ja vastuullisuutta. Yritysvastuuraportointi yhdistää yritysten lakisääteisen raportointi- ja tiedonantovelvollisuuden vapaaehtoiseen vastuullisuusviestintään. Vastuullisuusviestintä on keskeisessä asemassa myös yritysten riskienhallinnassa.

Viime vuosien aikana yritysvastuuraportoinnista on tullut erityisesti suurissa yrityksissä käytetty tapa viestiä toimintaan liittyvistä vastuullisuuskysymyksistä. Va- paaehtoisessa yritysvastuuraportoinnissa yhdistetään yleensä sekä niin sanottua "kovaa" eli todennettua, numeraalista ja/ tai rahamääräistä tietoa sekä "pehmeää" eli varmentamatonta, arvioihin ja kuvailuihin perustuvaa laadullista tietoa (Bertomeu \& Marinovic, 2015). Sekä Suomessa että kansainvälisesti valtaosa suuryrityksistä julkaisee laajoja yritysvastuuraportteja, joissa ne raportoivat taloudellisen, sosiaalisen ja ympäristövastuun kysymyksistä. Raporteissa käsitellään yhtäältä sitä, minkälaisia yhteiskunnallisia vaikutuksia yrityksen toiminnalla on sidosryhmille ja toisaalta sitä, miten yrityksessä hallitaan kestävän kehityksen kysymyksistä yritystoiminnalle aiheutuvia riskejä.

Viimeaikainen kehitys on korostanut erityisesti olennaisuutta yritysvastuuraportoinnin periaatteena. Raportoinnin kehittyessä ja yhteiskunnallisen tietoisuuden kasvaessa on huomattu, että raportit sisältävät suuren määrän tietoa, jonka yhteys toimintaympäristöön saattaa olla häilyvä ja vaihtelee vuosittain. Aiempi tutkimus on havainnut yritysten vapaaehtoisen raportoinnin olevan monin osin puutteellista ja keskittyvän yritystoiminnan positiivisiin vaikutuksiin (ks. esim. Bebbington \& Gray, 2001; Adams, 2004; MacLean \& Behnam, 2010). Olennaisuuden periaatteen tarkoituksena on auttaa yrityksiä keskittymään vastuullisuusraportoinnissa sidosryhmien kannalta merkitykselliseen tietoon niin, että sen perusteella on mahdollista muodostaa oikea ja riittävä kuva kyseisen yrityksen toiminnasta vastuullisuuden ja kestävän kehityksen näkökulmasta. Olennaisuuden käsittely 
tuo esiin raportoinnin moninaiset ja usein ristiriitaisetkin tavoitteet, mutta se myös auttaa yrityksiä kertomaan siitä, miten ne suhtatutuvat vastuullisuuteen ja tilivelvollisuuteen sekä siitä, miten sidosryhmät otetaan huomioon olennaisia asioita määriteltäessä (Puroila, 2015).

Viime aikoina on pohdittu paljon myös sitä, että yritysvastuuraportointia tulisi kehittää niin, että se tarjoaisi kokonaisvaltaisen kuvan yrityksen pitkän aikavälin arvonluontikyvystä huomioiden samalla yrityksen moninaiset tavoitteet ja resurssit. Integroitu raportointi (Integrated Reporting, IR) alkoi kehittyä Iso-Britanniassa vuonna 2004 osana laskentatoimen instituutioita kokoavaa The Prince's Accounting for Sustainability Project -ohjelmaa. Alkuvaiheen raporteissa yhdistettiin kestävän kehityksen raportointia yritysten perinteiseen tilinpäätösinformaatioon, mutta sittemmin keskusteluissa on korostunut yritystoiminnan kokonaisvaltaisten ja olennaisten sosiaalisten, taloudellisten ja ympäristövaikutusten, riskien ja mahdollisuuksien sekä monitahoisen arvonluonnin tasapainoinen raportointi. Samalla painopiste on siirtynyt yritysten yhteiskunnallisten vaikutusten raportoinnista sidosryhmille yrityksen kokonaisvaltaisen arvonluonnin strategian raportointiin sijoittajille.

Integroitu raportointi korostaa aiemmin monin erilaisin indikaattorein raportoidun sirpaleisen informaation kiteyttämistä olennaisuuden perusteella helposti ymmärrettävään muotoon. Taustalla on ajatus siitä, etteivät yritystoiminnan eri vaikutukset ja resurssit ole toisistaan erillisiä, vaan täydentävät ja vaikuttavat toinen toisiinsa. Esimerkiksi tavanomaisissa yhteiskuntavastuuraporteissa yritykset usein raportoivat ekologisesta, sosiaalisesta ja taloudellisesta vastuustaan erikseen, raportin eri osioissa ja eri indikaattorein. Integroidun raportoinnin viitekehyksessä yritystoimintaa ajatellaan kokonaisvaltaisena arvonluontina, johon kaikki nämä yritystoiminnan osa-alueet yhdessä osallistuvat, luovat arvoa ja toisaalta aiheuttavat riskejä, joita yrityksen tulee strategiassaan huomioida. Integroitu raportointi lähestyy yrityksen kokonaisvaltaista raportointia kuuden pääomalajin kautta: taloudellinen, tuotantorakenteiden, aineeton, inhimillinen, sosiaalinen ja luonnon pääoma. Pääomalajit voi yhtäältä ymmärtää yrityksen resurssina, joiden avulla arvoa luodaan, ja toisaalta riskitekijöinä, joita pitää hallita liiketoiminnan onnistumiseksi. Tärkeä näkökulma on myös tiedon tulevaisuussuuntautuneisuus. Kun esimerkiksi perinteinen tilinpäätösraportointi on keskittynyt historialliseen informaatioon yritysten suoriutumisesta, integroitu raportointi keskittyy yrityksen arvonluontiin tulevaisuudessa. Integroidussa raportoinnissa yritysvastuun näkökulmat yhdistyvät yrityksen liiketoimintaan, arvonluontiin ja strategiaan. Integroidun raportoinnin viitekehys linkittyy myös viimeaikaiseen tilinpäätösraportoinnin kehitykseen, jossa on painotettu ei-taloudellisen informaation sekä tulevaisuuteen suuntautuvan informaation merkitystä yritysten raportoinnissa (EU, 2014; IFRS, 2016).

Integroidun raportoinnin viitekehys on levinnyt nopeasti (Humphrey et al., 
2016), mutta itse raportointi on kuitenkin käytössä vasta harvoissa yrityksissä. Tällä hetkellä kansainvälisesti raportoivia yrityksiä on noin 100 . Suomessa esimerkiksi Finnairin, Keskon ja Ahlstromin on katsottu toteuttavan integroitua raportointia (Puroila, 2015; Niskala ja Pajunen, 2015). On kuitenkin huomattava, että integroitua raportointia käyttävien yritysten tunnistaminen on jossain määrin hankalaa, koska raportoinnin vaatimukset sisällön osalta ovat epäselvät eikä ole olemassa yksiselitteisiä kriteereitä sille, mikä on integroitua raportointia ja mikä jotain muuta. Koska yritysvastuuraportointi on toistaiseksi vapaaehtoista, valitsevat yritykset niin meillä kuin muuallakin tarjolla olevista viitekehyksistä itselleen sopivaksi räätälöidyn paketin, joka ei suoraan vastaa mitään viitekehystä sellaisenaan. Poikkeuksena mainittakoon Etelä-Afrikka, jossa yhteiskuntavastuuraportointi on pakollista ja sen on säädetty noudattavan IR-mallia (Steyn, 2014).

Tutkijoiden keskuudessa integroidun raportoinnin viitekehys on herättänyt kritiikkiä erityisesti sen korostuneen sijoittajakeskeisyyden (Flower, 2015) sekä konkreettisen raportointimittariston puutteen vuoksi (Cheng ym., 2014). Lisäksi on esitetty kritiikkiä siitä, ettei integroidun raportoinnin viitekehys sisällä todellista muutosvoimaa vaikuttaakseen organisaatioissa tai laajemmin yhteiskunnassa, sillä se jättää organisaatioille vapaat kädet raportoida itse olennaisiksi katsomistaan asioista (Flower, 2015; Thomson, 2015; Stubbs \& Higgins, 2014). Lisäksi on esitetty, että integroidun raportoinnin ajatus on lähtökohtaisesti mahdoton, sillä eri pääomalajien tasapainottamisen on katsottu olevan haasteellista, ellei jopa haitallista niiden erilaisen luonteen vuoksi. Esimerkkinä tästä voidaan mainita luontopääoman ja taloudellisen pääoman mittaamisen ja raportoinnin ristiriitaisuus. (Flower, 2015; Thomson, 2015; Brown \& Dillard, 2014; Cheng et al., 2014.)

Integroidun raportoinnin mahdollisuudet liittyvät sen kykyyn kannustaa sekä yksittäisiä yrityksiä että yritystoimintaa pohtimaan laajemmin liiketoimintamalliaan ja sitä, kuinka yritys luo toiminnallaan arvoa, kenelle ja millä aikavälillä. Integroidun raportoinnin viitekehys pakottaa yritykset arvioimaan ja kirkastamaan sekä liiketoimintamallinsa että arvonluontinsa kannalta olennaisia tekijöitä, riskejä ja resursseja ja arvioimaan tämän kaiken merkitystä suhteessa yrityksen strategiaan (Adams et al., 2016). Adams (2015) näkee tässä mahdollisuuden todelliseen muutokseen yritystoiminnassa sekä yritysten yhteiskunnallisessa roolissa laajemminkin. Näin yritysten sosiaaliseen ja ympäristövastuuseen liittyvät kysymykset tulisivat integroiduiksi yrityksen strategiaan ja ymmärrys yritysten tuottamasta arvosta saisi laajempia merkityksiä kuin vallitseva, osakkeenomistajien lyhyen tähtäimen voittoa painottava merkitys. Yrityksille, joilla on jo vastuullisuuteen perustuva strategia, integroitu raportointi voi tarjota mahdollisuuden kertoa toiminnastaan entistä laajemmin ja kokonaisvaltaisemmin.

Adams (2015) painottaa myös integroidun raportoinnin tuomia mahdollisuuksia yritysraportoinnin kokonaisvaltaiseen 
kehittämiseen yhteistyössä tutkijoiden, yritysten, lainsäätäjien ja laskenta-ammattilaisten kanssa. Monet raportoinnin tämän hetken ongelmista esimerkiksi mittaamisessa ja konkreettisen raportointimallin puuttumisessa voitaisiin nähdä kannustimina ja mahdollisuuksina uusien laskenta- ja raportointimallien kehittämiseen. Aiempi tutkimus on nähnyt integroidun raportoinnin hyötyinä myös sen tulevaisuussuuntautuneisuuden ja pitkän aikavälin tarkastelun (Adams \& Simnett, 2011; Watson, 2011; Hampton, 2012). Lisäksi integroitu raportointi on nähty tilaisuutena edistää riskienhallintaa, tuottaa entistä monipuolisempaa yritysinformaatiota (Hampton, 2012) sekä pienentää erilaisia kuiluja organisaation sisällä (Roberts, 2011).

Käytännössä yhden kokonaisvaltaisen raportin sijaan integroitu raportointi on toistaiseksi lisännyt yhden ylimääräisen raportin yrityksen tilinpäätösraportoinnin rinnalle, eikä tätä raporttia ole koettu ensisijaiseksi tiedonlähteeksi yrityksen toiminnasta (Rensburg \& Botha, 2014; Flower, 2015). Yritykset julkaisevat tyypillisesti erillisen yhteiskuntavastuuraportin taloudellisen raportin rinnalla, ja toisinaan myös vielä näistä erillisen GRI-yhteenvedon ja esimerkiksi erillisen corporate governance -raportin. Integroidun raportoinnin ei ole tarkoitus korvata lakisääteistä taloudellista raportointia tai yhteiskuntavastuuraportointia, vaan yhdistää näissä erillisissä raporteissa esitettyjä tietoja (Niskala \& Pajunen, 2015). Yritysten on toistaiseksi todettu ottaneen odottavan kannan suhteessa integroituun raportointiin (Watson, 2012; Rensburg \& Botha, 2014). On siis todennäköistä, että raportoinnin muodot kehittyvät edelleen ja sen tarjoamien mahdollisuuksien hyödyntäminen tulee lisääntymään tulevaisuudessa.

\section{Integroitu raportointi yritysvastuun mittaamisen näkökulmasta}

Yritysraportoinnilla nähdään yleensä olevan kaksi tarkoitusta. Yhtäältä se pyrkii lisäämään yritystoiminnan läpinäkyvyyttä ja toisaalta sen tavoitteena on yrityksen oman toiminnan mittaaminen ja ohjaus (Maas et al., 2016). Selvitysten mukaan yritysraportointia tehdään kuitenkin usein myös imagosyistä (KPMG, 2015; FIBS ry, 2015). Jotta raportoinnin alkuperäiset tavoitteet toteutuisivat, tulisi raportoinnin pohjautua luotettavaan, mitattuun tietoon yrityksen suorituskyvystä sekä vaikutuksista.

Alun perin integroidun raportoinnin odotettiin kehittävän sidosryhmälähtöistä kestävän kehityksen raportointia (Flower, 2015). Sittemmin viitekehyksen tavoite on kuitenkin siirtynyt sijoittajien päätöksenteon ja pääomamarkkinoiden tukemiseen (The International Integrated Reporting Council (IIRC), 2013). Esimerkiksi Finnairin vuoden 2015 raportista on todettu, että vastuullisuuden raportoinnin lähtökohtana on yhtiön taloudellisten sidosryhmien etujen turvaaminen, ei kaikkien sidosryhmien odotukset tai tiedontarpeet ja että vastuullisuuden raportointi on kokonaisuudessaan suppeampaa kuin perinteisessä yritysvastuuraportissa (Harberg, 2016). Integroidun raportoinnin tavoitteena ei siis ole tuottaa informaatiota yrityksen 
yhteiskunnallisista vaikutuksista, toisin kuin usein ajatellaan (Flower, 2015). Näin ollen ei ole yllättävää, ettei integroitu raportointi tarjoa mallia tai mittaristoa siihen, mitä raportin tulisi pitää sisällään. Integroitu raportointi ei myöskään määrittele, minkälaisessa muodossa raportti tuotetaan. Integroidun raportoinnin viitekehystä onkin kritisoitu siitä, ettei se juurikaan tarjoa parannusta kestävän kehityksen raportoinnin haasteisiin eikä tuota sidosryhmille tietoa yrityksen yhteiskunnallisista vaikutuksista (Thomson, 2015; Flower, 2015).

Integroidun raportoinnin viitekehyksessä korostetaan, että yrityksen tulee keskittyä raportoinnissaan olennaiseen, eikä sen näin ollen tarvitse lainkaan raportoida sellaisista kestävän kehityksen asioista, joita ei katsota olennaisiksi sen kokonaisvaltaisen arvonluonnin näkökulmasta. Jos yritysvastuun ja kestävän kehityksen kysymyksiä kuitenkin pidetään olennaisina yrityksen arvonluonnin kannalta, voidaan integroitua raportointia käyttää myös niiden raportoimiseen.

Perinteisessä tilinpäätösraportoinnissa olennaiseksi tiedoksi määritellään sellainen tieto, jonka puuttuminen tai virheellisyys voi vaikuttaa raportoivasta yksiköstä taloudellisen tiedon perusteella tehtäviin päätöksiin (Unerman \& Zappettini, 2014). Olennaisuus on näin sekä tilanne- että yrityskohtaista, ja yleisiä ohjeita voidaan antaa vain siitä, miten olennaisuuden määrittely tulisi toteuttaa. Tästä syystä erityistä huomiota tulisikin kiinnittää olennaisuuden määrittelyprosessiin, jossa voidaan käyttää hyväksi esimerkiksi Glo- bal Reporting Initiativen (2013) ohjeita ja niiden sisältämää olennaisuusmatriisia. Ohjeiden mukaan raporttiin tulisi sisällyttää kaikki sellaiset asiat, jotka ovat merkityksellisiä yrityksen tai organisaation taloudellisten, sosiaalisten ja ympäristövaikutusten kannalta. Olennaisuusmatriisi koostuu yleensä kahdesta ulottuvuudesta, joiden mukaan asian olennaisuus määritellään ja priorisoidaan suhteessa muihin olennaisiksi katsottuihin asioihin. GRI:n määritelmässä nämä matriisin kaksi ulottuvuutta ovat asian vaikutus sidosryhmien päätöksentekoon ja asian taloudellisten, sosiaalisten ja ympäristövaikutusten merkittävyys (GRI, 2013). Käytännössä yrityksissä käytetään vaihtelevia kriteereitä olennaisten asioiden määrittämiseksi (Puroila, 2015).

Integroitu raportointi korostaa raportointia yrityksen arvonluonnin näkökulmasta sekä kokonaisvaltaisen arvonluontitarinan rakentamista. Yritys ei luo arvoa yksinään, vaan yhteistyössä ja vuorovaikutuksessa eri sidosryhmiensä kanssa (Freeman et al., 2007; Myllykangas et al., 2010). Arvonluonti on myös riippuvainen erilaisista resursseista ja pääomalajeista. Perinteisessä taloudellisessa raportoinnissa yrityksen arvonluonti on ymmärretty ensisijassa taloudellisesta näkökulmasta, minkä seurauksena esimerkiksi monet ympäristö- ja sosiaalisen vastuun tekijät ja muut IR:n mukaiset pääomalajit on päätöksenteossa pyritty rahamääräistämään esimerkiksi niihin uhrattujen kustannusten perusteella. Uudemmassa arvonluontikeskustelussa arvo nähdään myös laadullisena, ja se voi tarkoittaa eri asioita 
eri sidosryhmille (Myllykangas, 2009). Laadullisen tiedon avulla raportista on mahdollista rakentaa yrityksen kokonaisvaltainen arvonluontitarina, joka huomioi taloudellisten mittareiden lisäksi myös moninaiset sidosryhmäarvot. Näin tuloksena on monipuolinen tarina siitä, mikä on keskeistä yrityksen arvonluonnissa.

Tarkkojen mittareiden ja mittaamisen sijaan integroitu raportointi painottaa siis yrityksen sijoitustarinan kerrontaa, eli se on raportointia tarinankerrontana (IR, 2013; Higgins, Stubbs \& Love, 2014). Tarkoitus on yhtäältä esittää yrityksen pitkän aikavälin strategia arvonluonnin näkökulmasta ja toisaalta käsitellä myös liiketoiminnan vaikutukset monipuolisesti eri pääomalajien kautta. Sijoittajatarinassa huomioidaan olennaisten pääomalajien lisäksi myös aikaväli: arvonluontia pitäisi osata kuvata sekä lyhyellä, keskipitkällä että pitkällä aikavälillä.

Integroitu raportointi tarjoaa yleisellä tasolla työkaluja raportointimallin käyttöönottoon. Ensimmäinen vaihe integroidun raportoinnin aloittamisessa on yrityksen sidosryhmien tunnistaminen ja heidän roolinsa pohtiminen yrityksen arvonluontiprosessissa. Tässä voidaan käyttää apuna erilaisia sidosryhmäanalyysin työkaluja, kuten AOP-matriisia tai sidosryhmätärkeyden viitekehystä. AOP-matriisissa kiinnitetään huomiota sidosryhmien arvoihin, odotuksiin ja panostuksiin, ja se auttaa ymmärtämään eri sidosryhmien luonnetta ja merkitystä liiketoiminnan arvonluonnissa (Kujala \& Kuvaja, 2002). Sidosryhmätärkeyden viitekehys taas auttaa pohtimaan sidosryhmien odotusten kiireellisyyttä ja oikeutusta sekä sidosryhmien valtaa suhteessa yritykseen (Mitchell et al., 1997).

Seuraavassa vaiheessa kannustetaan tarkastelemaan eri sidosryhmien ja pääomalajien merkitystä yrityksen strategiassa ja sen toteuttamisessa. Yrityksen tulisi pohtia, onko kokonaisvaltainen arvonluonnin ajatus ja eri pääomalajien toisiaan täydentävät ominaisuudet käytännössä huomioitu yrityksen arvonluonnissa. Jos eri pääomalajien huomataan edelleen olevan arvonluonnin näkökulmasta erillisiä toisistaan, tulisi pohtia, miten niitä voisi lähentää. Myös tiedon aikasuuntautuneisuutta tulee pohtia: menneisyydestä raportoinnin lisäksi integroitu raportointi pyrkii kertomaan myös tulevaisuuden arvonluontitarinaa eli antamaan tietoa siitä, miten yritys tulee vastaisuudessa toteuttamaan strategiaansa ja vastaamaan sidosryhmiensä odotuksiin.

Kolmannessa eli viimeisessä vaiheessa muodostetaan sijoittajatarina eli viestitään yrityksen strategiasta mahdollisimman selkeästi ja ytimekkäästi kaikki pääoman lajit huomioiden. Tarinat ovat kautta aikojen olleet tapa välittää eteenpäin ja kertoa siitä, mitä pidetään tärkeänä, tavoiteltavana, sopivana ja oikeana (Lehtimäki, 2000). Tarina vakuuttaa lukijansa vetoamalla arvoihin ja tunteisiin, mutta siihen voi myös yhdistää järkeen ja talouteen liittyvää informaatiota. Tarinan muodossa olevan raportoinnin avulla yritys voi tehdä itselleen ja muille ymmärrettäväksi omaa toimintaansa, sen lähtökohtia ja tavoitteita. 


\section{Mittareiden haasteet}

\section{integroidussa raportoinnissa}

Se, mitä integroidussa raportoinnissa tulisi mitata, riippuu siitä, mitä raportoinnilla tavoitellaan. Jos tavoitteena on yrityksen yhteiskunnallisten vaikutusten kuvaus, tulisi raportoinnin tavoitteena olla olennaisen, johdonmukaisen ja vertailukelpoisen informaation tuottaminen yrityksen yhteiskunnallisista vaikutuksista. Koska integroitu raportointi korostaa kuitenkin sijoittajan näkökulmaa ja luotettavan tiedon tarjoamista sijoittajan päätöksenteon tueksi, tulisi eri pääomalajien positiiviset ja negatiiviset vaikutukset huomioida sen mukaan, miten ne osallistuvat sijoittajaarvon tuottamiseen.

Olipa kyse sitten laajemmasta yritysvastuun tai kapeammasta sijoittaja-arvon tuottamisen raportoinnista, haasteeksi nousevat informaation tunnistamisen lisäksi mittaamiseen liittyvät kysymykset tiedon määrällistämisestä ja rahamääräistämisestä. Esimerkiksi ympäristövaikutukset (tai -resurssit) voi olla vaikea rajata mitattavissa olevaksi kokonaisuudeksi. Lisäksi monet tässä hetkessä aiheutetut ympäristövaikutukset realisoituvat vasta vuosikymmenten päästä. Ja jos vaikutukset olisivatkin tässä hetkessä tunnistettavissa, on vielä pohdittava, miten ja minkälaisen prosessin kautta niille määritettäisiin rahamääräinen arvo. Erilaisten pääomalajien integroiminen yhteen raporttiin tuokin mukanaan haasteita muun muassa raportoinnin jaksottamiseen ja raportoinnin aikakäsitykseen. Taloudellinen raportointi eli tilinpäätös tuotetaan lakisääteisesti vuosittain, ja sen tulee pitää sisällään kaikki kyseiselle ajanjaksolle jaksotetut tuotot ja kulut. Jaksotuksen tekeminen integroidun raportoinnin pääomalajien suhteen on kuitenkin haastavampaa. Integroidussa raportoinnissa tämä on toistaiseksi ohitettu sanomalla, että raportointi voi olla myös sanallista ja kerronnallista. Tällainen tarinallinen raportointi herättää kuitenkin uusia kysymyksiä raportoinnin johdonmukaisuudesta ja informaation vertailukelpoisuudesta.

Integroidun raportoinnin viitekehys ei siis tarjoa varsinaisia indikaattoreita tai muuta sisällöllistä tukea raportoinnin tueksi. Monet yritykset käyttävät raportointiin Global Reporting Initiative eli GRI-ohjeistusta ja tuottavat raporttinsa sen tarjoamaa viitekehystä ja indikaattoreita soveltaen. Se, kuinka hyvin nämä kestävän kehityksen mittarit vastaavat integroidun raportoinnin ajatusta kokonaisvaltaisesta arvonluonnista, on kuitenkin vielä epäselvää.

\section{Miltä integroidun raportoinnin tulevaisuus näyttää?}

Integroidun raportoinnin tulevaisuus on monella tapaa avoin. Alkuperäiset toiveet integroidun raportoinnin potentiaalista kehittää kestävän kehityksen raportointia ovat saaneet osakseen paljon kritiikkiä, mutta moni näkee integroidussa raportoinnissa myös mahdollisuuksia raportoinnin kokonaisvaltaiseen kehittämiseen. Kestävän kehityksen ja laajan sidosryhmäjoukon näkökulmasta raportoinnin kehitys ei kuitenkaan vaikuta lupaavalta, koska viitekehyksen painopiste on selkeästi siirtynyt sijoittajien näkökulman korostamiseen. 
Se, miten kokonaisvaltaiseen arvonluontiin keskittyvän arvonluontitarinan rakentaminen vaikuttaa yrityksen sisäisiin tavoitteisiin ja prosesseihin tai yritystoiminnan yhteiskunnalliseen rooliin laajemmin, jää myös nähtäväksi. Raportoinnin kehitys pitää sisällään myös monia käytännön toteutukseen liittyviä kysymyksiä, joilla on laaja-alaisia merkityksiä, kuten esimerkiksi vaikutusten mittaamiseen ja arvottamiseen sekä sidosryhmävuorovaikutukseen liittyvät kysymykset. Integroitu raportointi voi lähentää yrityksen sisäisiä toimintoja ja henkilöstöä, kuten esimerkiksi talous-, viestintä- ja ympäristötoimintoja, samoin kuin yrityksien eri sidosryhmiä osallistamalla eri tahoja itse raportointiprosessiin kokonaisvaltaisen sijoittajatarinan luomiseksi.

Tarinallisuus raportoinnissa on ajankohtaista, ellei jopa trendikästä, ja onkin mielenkiintoista nähdä, miten se tulevaisuudessa suhteutetaan raportoinnin laadun vaatimuksiin. Integroidussa raportoinnissa tarinallisuutta voidaan käyttää raportin viimeistelyn periaatteena. Tällöin raportin sisältämät kuvaukset eri pääomalajeista ja niiden merkityksestä strategian toteutuksessa ja arvonluonnissa puetaan tarinan muotoon. Tarinalliseen raporttiin on mahdollista yhdistää myös visuaalisuutta ja konkreettisia esimerkkejä käytännön toiminnasta. Raportit tulevat siten mielenkiintoisemmiksi ja ymmärrettävämmiksi myös laajalle yleisölle. Näin raportit toimivat viestintäkanavana ja maineen rakentajana paitsi ammattimaisen sijoittajayleisön myös laajemman sidosryhmäjoukon keskuudessa. Tarinalli- sella raportilla onkin perinteistä raporttia laajempi lukijakunta, sillä se on helposti lähestyttävissä ja ymmärrettävissä.

Pohdittaessa integroidun raportoinnin mahdollisuuksia ja käytännön vaikutuksia monet teemat kaipaavat kuitenkin vielä selkeyttämistä (vrt. Adams, 2015). Raportoinnin pitäisi selvästi huomioida se, että arvo ja arvonluonti ovat itsessään monitulkintaisia käsitteitä ja tarkoittavat eri asioita eri sidosryhmille. Lisäksi pitää muistaa myös se, että monet uudet arvon ulottuvuudet ovat sellaisia, joita ei ole aiemmin mitattu, ja niiden mittaaminen voi ylipäänsä olla mahdotonta. Yritysten tulisi raportoinnissaan kertoa, miten arvoluonti on ymmärretty, minkälaisia mahdollisesti ristiriitaisiakin käsityksiä eri sidosryhmillä on arvonluonnista, ja miten yritys on nämä eri näkemykset huomioinut. Lisäksi yritysten tulisi raportoida arvonmäärityksen prosesseista sekä siitä, minkälaisia konkreettisia vaiheita arvonluontiin liittyy kaikkien kuuden pääomalajin osalta. Yritysten tulisi myös käyttää riippumatonta, ulkopuolisen tahon suorittamaa varmennusta osoittamaan, että yritys todella toimii sanojensa mukaisesti.

Integroidun raportoinnin on sanottu olevan tulevaisuussuuntautunutta. Kun perinteinen tilinpäätösraportointi ja kestävän kehityksen GRI-standardit raportoivat lähinnä yrityksen menneestä suorituskyvystä, tuo tämä tulevaisuussuuntautunut raportointi uusia haasteita yritysviestintään ja mittaamiseen. Tämä tarjoaa mahdollisuuden pohtia yritysraportointia ja informaatiota yritysten suorituskyvystä laajemmin. Se, miten esimerkiksi laskenta- 
toimessa tärkeät periaatteet informaation laadusta, kuten johdonmukaisuuden ja vertailukelpoisuuden periaatteet, tulevat sovelletuksi tarinallisen tulevaisuusinformaation osalta, saa toivottavasti ansaitsemansa huomion. Raportoinnin näkökulmasta on myös mielenkiintoista seurata integroidun raportoinnin käytäntöjen mahdollista vakiintumista ja esimerkiksi sitä, millaisia aikavälejä raportointi jatkossa tarkastelee ja millaisin mittarein tulevaisuudesta voi raportoida. Vastauksia näihin kysymyksiin vasta pohditaan ja ne ovatkin integroidun raportoinnin keskeisiä kehityskohteita.

\section{Lopuksi: Yritysvastuun integroidun raportoinnin seitsemän viisautta}

1. Määritä raportoinnin lähtökohdat yritysvastuun näkökulmasta ja varmista johdon sitoutuminen.

2. Tunnista sidosryhmäsi.

3. Osallista sidosryhmät raportointiprosessiin mahdollisimman varhaisessa vaiheessa.

4. Määritä sidosryhmien avulla, mitkä ovat oleellisia asioita raportoinnissa.

5. Tunnista yrityksesi käytössä olevat keskeiset resurssit ja eri pääomalajit.

6. Tunnista yrityksesi vaikutukset sidosryhmien ja yhteiskunnan kannalta.

7. Pohdi, millainen tarina sopii yritysvastuun viestintään ja puhuttelee eri sidosryhmiä.

\section{Näistä voit aloittaa:}

1) The International Integrated Reporting Council (IIRC) (2013). The International
$<I R>$ Framework. Saatavilla verkossa: http://integratedreporting.org/wp-content/ uploads/2015/03/13-12-08-THE-INTERNATIONAL-IR-FRAMEWORK-2-1.pdf.

2) Global Reporting Initiative (2013). An introduction to G4. Saatavilla verkossa: www.globalreporting.org/resourcelibrary/ GRI-An-introduction-to-G4.pdf.

\section{LÄHTEET}

Adams, S. \& Simnett, R. (2011). Integrated reporting: An opportunity for Australia's notfor-profit sector. Australian Accounting Review, 21(3), 292-301.

Adams, C. A. (2015). The international integrated reporting council: a call to action. Critical Perspectives on Accounting, 27, 23-28.

Adams, C. A. (2004). The ethical, social and environmental reporting-performance portrayal gap. Accounting, Auditing \& Accountability Journal, 17(5), 731-757.

Adams, C. A., Potter, B., Singh, P. J. \& York, J. (2016). Exploring the implications of integrated reporting for social investment (disclosures). The British Accounting Review, 48(3), 283-296.

Bertomeu, J. \& Marinovic, I. (2015). A theory of hard and soft information. The Accounting Review, 91(1), 1-20.

Bebbington, J. \& Gray, R. H. (2001). An account of sustainability: Failure, success and a reconceptualization. Critical Perspectives on 
Accounting, 12, 557-587.

Brown, J. \& Dillard, J. (2014). Integrated reporting: On the need for broadening out and opening up. Accounting, Auditing \& Accountability Journal, 27(7), 1120-1156.

Cheng, M., Green, W., Conradie, P., Konishi, N. \& Romi, A. (2014). The international integrated reporting framework: key issues and future research opportunities. Journal of International Financial Management \& Accounting, 25(1), 90-119.

de Villiers, C., Rinaldi, L. \& Unerman, J. (2014). Integrated reporting: Insights, gaps and an agenda for future research. Accounting, Auditing \& Accountability Journal, 27(7), 1042-1067.

EU Commission (2014). Directive 2014/95/EU of the European Parliament and the Council of 22 October 2014 amending Directive 2013/34/ EU as regards disclosure of non-financial and diversity information by certain large undertakings and groups. ABIEU L, 330, 1-9.

FIBS ry (2016). FIBSin yritysvastuututkimus 2016: yritysten käytännöt, haasteet ja tulevaisuuden näkymät. Saatavilla verkossa: http://www.fibsry. fi/images/FIBS_Yritysvastuututkimus2016_Tiivistelma.pdf

Flower, J. (2015). The international integrated reporting council: A story of failure. Critical Perspectives on Accounting, 27, 1-17.

Freeman, R. E., Harrison, J. \& Wicks, A. (2007). Managing for Stakeholders. Survival, Reputation, and Success. London: Yale University Press.
Global Reporting Initiative (2013). An introduction to G4. Saatavilla: www.globalreporting.org/ resourcelibrary/GRI-An-introduction-to-G4.pdf. Luettu 12.1.2017.

Harberg, P. (2016). Yhteiskuntavastuu integroidussa raportoinnissa. Pro gradu -tutkielma. Tampere: Tampereen yliopisto.

Hampton, R. (2012). Brace yourself for more regulatory changes. Accountancy SA, May, 22-23. Higgins, C., Stubbs, W. \& Love, T. (2014). Walking the talk(s): Organisational narratives of integrated reporting. Accounting, Auditing \& Accountability Journal, 27(7), 1090-1119.

Humphrey, C., O’Dwyer, B. \& Unerman, J. (2016). Re-theorizing the configuration of organizational fields: The IIRC and the pursuit of 'Enlightened' corporate reporting. Accounting and Business Research 47(1), 1-34.

IFRS (2016). IASB Chairman to prioritise communication effectiveness of financial statements during second term. Saatavilla: http://www.ifrs. org/Current-Projects/IASB-Projects/Disclosure-Initiative/Principles-of-Disclosure/Project-news/Pages/Project-news-June-2016.aspx. Luettu 12.1.2017.

The International Integrated Reporting Council (IIRC) (2013). The International $<I R>$ Framework. Saatavilla: http://integratedreporting.org/ wp-content/uploads/2015/03/13-12-08-THE-INTERNATIONAL-IR-FRAMEWORK-2-1.pdf. Luettu 12.1.2017.

KPMG (2015). The KPMG Survey of Corporate Responsibility Reporting 2015. Saatavilla: https:// 
home.kpmg.com/xx/en/home/insights/2015/11/ kpmg-international-survey-of-corporate-responsibility-reporting-2015.html. Luettu: 12.1.2017.

Kujala, J. \& Kuvaja, S. 2002. Välittävä johtaminen. Sidosryhmät eettisen liiketoiminnan kirittäjinä. Helsinki: Talentum.

Lehtimäki, H. (2000). Strategiatarina kaupungista ja sen toimijoista. Tampere: Tampere University Press.

MacLean, T. L. \& Behnam, M. (2010). The dangers of decoupling: The relationship between compliance programs, legitimacy perceptions, and institutionalized misconduct. Academy of Management Journal, 53(6), 1499-1520.

Mitchell, R. K., Agle, B. R. \& Wood, D. J. (1997). Toward a theory of stakeholder identification and salience: Defining the principle of who and what really counts. Academy of Management Review, 22(4), 853-886.

Myllykangas, P. (2009). Sidosryhmäsuhteet liiketoiminnan arvon luomisessa. Palveluyksiköstä liiketoiminnaksi, episodi yrityksen elämään. Tampere: Tampere University Press.

Myllykangas, P., Kujala, J. \& Lehtimäki. (2010). Analyzing the essence of stakeholder relationships: What do we need in addition to power, legitimacy and urgency? Journal of Business Ethics, 96(1), 65-72.

Niskala, M. \& Pajunen, T. (2015). Kohti integroitua raportointia. Porvoo: ST-Akatemia.

Puroila, J. (2015). What really matters? Materiality disclosures in sustainability reporting practices.
Pro gradu -tutkielma, Tampere: Tampereen yliopisto.

Rensburg, R. \& Botha, E. (2014). Is integrated reporting the silver bullet of financial communication? A stakeholder perspective From South Africa. Public Relations Review, 40, 144-152.

Steyn, M. (2014). Organisational benefits and implementation challenges of mandatory integrated reporting: Perspectives of senior executives at South African listed companies. Sustainability Accounting, Management and Policy Journal, 5(4), 476-503.

Stubbs, W. \& Higgins, C. (2014). Integrated reporting and internal mechanisms of change. Accounting, Auditing \& Accountability Journal, 27(7), 1068-1089.

Thomson, I. (2015). 'But does sustainability need capitalism or an integrated report' a commentary on 'The International Integrated Reporting Council: A story of failure' by Flower, J. Critical Perspectives on Accounting, 27, 18-22.

Unerman, J. \& Zappettini, F. (2014) Incorporating materiality considerations into analyses of absence from sustainability reporting. Social and Environmental Accountability Journal 34(3), 172-186.

Van Bommel, K. (2014). Towards a legitimate compromise? An exploration of Integrated Reporting in the Netherlands. Accounting, Auditing \& Accountability Journal, 27(7), 1157-1189. 


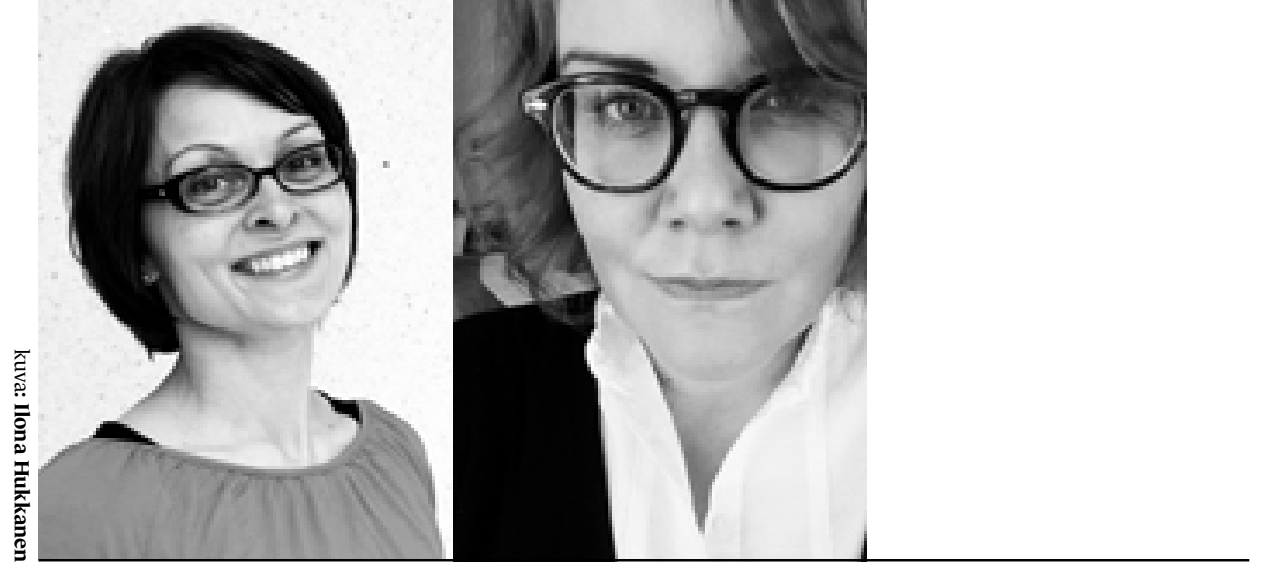

KETKÄ?

\section{Petriikka Ohtonen ja Elina Ollila}

- Petriikka Ohtonen on viestinnän johtamisen maisteriopiskelija Jyväskylän yliopistossa. Ennen viestinnän opintoja hän on työskennellyt valtiolla $\mathrm{mm}$. viestinnän ja henkilöstöhallinnon tehtävissä sekä opiskellut yhteiskuntatieteitä. Ohtonen on kiinnostunut erityisesti viestinnän roolista suhteessa organisaation strategiseen toimintaan. Kiinnostus mittaamiseen heräsikin halusta osoittaa viestinnän vaikuttavuus ja hyöty organisaatiolle.

Elina Ollila on yhteisöviestinnän maisteriopiskelija Jyväskylän yliopistosta ja yhteiskuntatieteiden maisteri Lapin yliopistosta (pääaine kansainväliset suhteet). Ollila työskentelee tällä hetkellä Kriisinhallintakeskuksen tiedottajana, aiemmin hän on toiminut muun muassa Kansainvälisen Siirtolaisuusjärjestö IOM:n Kosovon-mission tiedottajana sekä sisällöntuotantotehtävissä lontoolaisessa mediatalossa. Ollila on kiinnostunut viestinnän vaikuttavuudesta erityisesti syrjäytymiseen, konflikteihin ja kehitykseen liittyvien kysymysten yhteydessä. 
VIESTINNÄN ROI

- MAHDOLLISUUS

VAI MAHDOTTOMUUS?

$V$

iestinnän kytkeytyessä entistä tiiviimmin johtamiseen ja organisaation strategisiin tavoitteisiin on tullut tarpeelliseksi löytää uusia välineitä viestinnän tulosten osoittamiseksi. Tuottavuuden kysymykset ovat taloustiedettä, jonka käsitteitä on soviteltu myös viestinnän viitekehykseen. Yksi näistä on sijoitetun pääoman tuottoprosentti eli ROI (Return on Investment). Akateemisten ja ammattilaislähteiden mukaan ROIn avulla pyritään osoittamaan viestinnän avulla saavutettu tuotto tai kustannussäästöt, mutta sen soveltuvuus tähän tarkoitukseen ei ole yksiselitteinen. Tässä artikkelissa tuomme esille erilaisia näkökulmia ROIn määrittelyyn ja käyttöön, sillä alan hyväksymää yhteistä määritelmää sille ei vielä ole. Tarkoituksena on avata määrittelyperusteita helpottamaan keskustelua viestinnän vaikuttavuudesta niin kampanja- kuin strategisellakin tasolla.

\section{Johdanto: mitä on Return on Investment?}

Taloustieteessä Return on Investment (ROI) on kaava, jolla osoitetaan investointien tuottoprosentti tai tuottoaste seuraavasti:

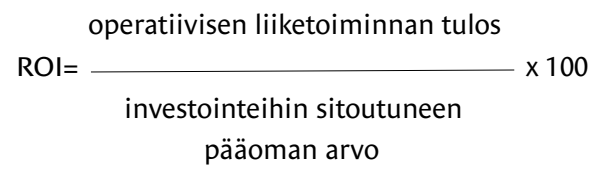

(Järvenpää, Länsiluoto, Partanen \& Pellinen, 2015).

Laskentatoimen piirissä ROIta pidetään yhtenä pääoman käytön kannattavuuden keskeisenä mittarina. Käytännössä se lasketaan nettotuloksesta (Stacks \& Bowen, 2013), eli tuloksesta, josta on vähennetty kulut, mutta lähtökohdaksi on esitetty myös saavutettuja säästöjä (Meng \& Berger, 2012). ROI ilmaistaan prosenttimuodossa.

Suhdetoiminnan, markkinoinnin ja viestinnän sanastossa ROI-käsite on ollut mukana jo useamman kymmenen vuoden ajan (Watson, 2011). Lähtökohtaisena tavoitteena on ollut osoittaa numeerisesti viestinnän taloudellinen hyöty organisaatiolle. Sitä on PR-alalla jopa esitetty ylivoimaiseksi mittariksi ilmentämään PR-viestinnän arvoa organisaatiolle (Macnamara, 2014). Iso-Britanniassa vuonna 2010 tehdyn tutkimuksen mukaan 66,7 prosenttia viestinnän ammattilaisista ilmoitti käyttävänsä ROIta mitatessaan omaa työtään ja sen tuloksia (Watson, 2011). Suomessa taas STT Viestintäpal- 
veluiden ja ProComin (2016) teettämän tutkimuksen mukaan lähes viidennes päällikkötason viestinnän ammattilaisista ilmoitti organisaatioidensa seuraavan viestinnän ROIta.

ROI-käsitteen käyttö ei kuitenkaan kerro siitä, miten ja missä muodossa sitä käytetään. Vuonna 2011 tehdyn laajemman eurooppalaisen tutkimuksen mukaan ROIn määrittelyssä on havaittavissa kaksi erillistä näkökulmaa — taloudellinen ja ei-taloudellinen. Näistä taloudellinen näkökulma on lähempänä perinteistä ROI-määrittelyä. Kuitenkin vain 52,8 prosenttia vastaajista hyväksyi ROI-määritelmän "viestintätoiminnoista muodostuvan taloudellisen voiton suhde sen tosiasiallisiin kustannuksiin". (Watson \& Zerfass, 2011.)

ROIn osoittamisen tarvetta perustellaan rajatuilla taloudellisilla resursseilla, jotka asettavat myös viestinnän tulosvastuulliseksi (Likely, Rockland \& Weiner, 2006). Viestinnän on kyettävä kehittämään mittaristoaan osoittaakseen tarpeellisuutensa sekä ansaitakseen roolinsa osana organisaation strategista päätöksentekoa ja johtamista (Grunig, 2006). Pelkkä viestinnän tehokkuuden osoittaminen ei riitä, vaan vaaditaan kykyä osoittaa sen vaikuttavuus ja viestinnällä saavutettujen tulosten merkitys liiketoiminnan tuloksiin.

Oleellista onkin pohtia, mitä tietty ROI-määritelmä kertoo ja pystytäänkö sitä käyttämällä vastaamaan asetettuun kysymykseen.

\section{Käsitteiden viidakossa}

Viestinnän akateemisessa ja johtavien ammattilaisten diskurssissa ROI asetetaan yleensä vaikuttavuuden tasolle (mm. Stacks \& Bowen, 2013; Grunig, 2006 ja 2008; AMEC; ECM), jossa arviointi kohdistuu koko organisaation viitekehykseen (Kim \& Yang, 2013; Grunig, 2006; Watson, 2011). Viestinnän arvioinnin luokittelusta riippumatta tällä viitataan strategiseen tasoon, ei ainoastaan viestinnän tavoitteiden taktiseen tai toiminnan operatiiviseen tasoon. Se nähdään myös lähtökohtaisesti summatiivisena arviointina, joka suuntautuu taaksepäin sisältäen lopullisen tuloksen (Watson \& Noble, 2007). PR-sanakirja esittää, että ROI PR-viestinnässä (PR ROI) on viestintäohjelman vaikutus liiketoiminnan tuloksiin. ROI osoittaisi näin viestintäsijoituksen kausaalisen suhteen liiketoiminnan mittareihin (Stacks \& Bowen, 2013). Tämä määritelmä suuntaa ROIn merkittävästi pois alkuperäisestä laskentatoimen määritelmästä sisällyttäen siihen muitakin kuin taloudellisia indikaattoreita (Macnamara, 2014).

Miten ROI tulisi sitten rakentaa? Taloudelliset kaavat tarvitsevat selkeät numeeriset tai euromääräiset arvot. Viestinnässä mittaamisen perushaasteena onkin se, miten määrällistetään viestinnän aineettomat tulokset, kuten muutokset asenteissa ja edelleen käyttäytymisessä, sekä aineeton hyöty, joka ilmenee maineena, suhteina ja sitoutumisena. ROIn osalta erityisenä haasteena on se, miten vaikutussuhde näiden aineettomien tulosten ja taloudellisen tuoton välillä ymmärretään. Akateeminen ja ammattikirjallisuus tarjoavat erilaisia malleja, joilla pyritään tavoittamaan tämä viestinnän vaikutus 
organisaation tuottoon.

Perinteisesti viestinnän arvoa on pyritty määrittelemään medianäkyvyyden kautta. Yksi laajasti käytetty tapa on kertoa mediassa ansaitut palstamillit tai sekuntit kyseisen median mainoskuluilla. Tämä AVE (Advertising Value Equivalency) sekä sen johdannaiset, kuten ROEM (Return on Earned Media) (Likely, Rockland \& Wiener, 2006), ovat paitsi akateemisessa myös ammattilaisdiskurssissa hylättyjä käsitteitä, koska ne eivät ilmaise viestinnän arvoa eivätkä kuvaa saadun julkisuuden laatua (Watson \& Noble, 2007; IPR, 2015), saati osoita linkkiä liiketoiminnan tulokseen. Näitä ei voida käyttää ROIna, vaan ainoastaan kustannustehokkuuden viitteellisenä mittarina pohdittaessa vaihtoehtoja mainonnalle (Likely et al., 2006).

Yhtenä vaihtoehtona on esitetty keskittymistä ansaitun sisällön tai viestin vastaanottomahdollisuuksien kokonaismäärään (OTS, Opportunities To See) eri medioissa suhteuttamalla niiden tuottamiseen sijoitettuja kuluja kokonaistuottoon (ROI, Return on Impression) (Likely, Rockland \& Wiener, 2006). Ongelmana on, että malli olettaa lineaarisen vaikutuksen vaikutelmista käyttäytymiseen. Vaikutusta voidaan pyrkiä tavoittamaan kyselyillä ennen ja jälkeen kampanjan keskittyen tiettyyn kohderyhmään (ROTI, Return on Target Influence) (Likely, Rockland \& Wiener, 2006). Digitaalinen ja erityisesti sosiaalinen media ovat laajentaneet mediaseurantaa mahdollistaen uudenlaisten muuttujien hyödyntämisen viestinnän tulosten arvioinnissa. Voidaan puhua sosiaalisen median ROIsta (Social Media
$R O I$ ), jossa perinteisiä laadullisia ja määrällisiä muuttujia yhdistetään digitaalisen ympäristön muuttujiin (mm. sävyt, suosittelut, jaot, klikkaukset, konversiot, sitoutuminen ja osallistuminen). Konversiolla viitataan tavoitteeseen, kuten uutiskirjeen tilaamiseen, jonka kävijä toteuttaa sivulla. (ks. mm. Töllinen \& Karjaluoto, 2011.) Delahaye Paine (2011) esittää, että ROIsta voidaan puhua esittämällä yhteys myyntiin, säästettyihin kuluihin, ansaittuun hakukonesijoitukseen, vältettyihin kuluihin tai saavutettuun sosiaaliseen pääomaan.

Markkinoinnin alalla ROI yhdistetään muun muassa brändiin (ROBI, Return on Brand Investment) ja asiakkaaseen (ROCI, Return on Customer Investment ja ROC, Return on Customer) (Meng \& Berger, 2012; Töllinen \& Karjaluoto, 2011). Paitsi viestinnän myös markkinoinnin puolella Return on -alkuisten käsitteiden laajenevaa käyttöä pidetään ongelmallisena, koska monimuotoisuuden ei nähdä edistävän standardeja eikä lisäävän ymmärrystä tuoton osoittamiseen (Watson \& Noble, 2007; Macnamara, 2015; Töllinen \& Karjaluoto, 2011). Myöskään käsitteiden määrittelyt eivät aina ole täysin tyhjentäviä. Lisäksi markkinoinnin ja viestinnän kautta syntyneiden tulosten erottaminen on usein vaikeaa, ellei mahdotonta.

Vaihtoehtona viestinnän ja liiketoiminnan tulosten kausaalisen suhteen osoittamiselle on tarjottu ekonometrisiä malleja, joilla pyritään tavoittamaan useamman eri muuttujan välisiä suhteita käyttäen apuna tilastomenetelmiä. Markkinoinnin piirissä mallinnusta kutsutaan nimellä Marketing Mix Modelling (MMM), toisi- 
naan myös Media Mix Modelling. Likely, Rockland ja Wiener (2006) kutsuvat tätä nimellä Return on Media Impact (ROMI). Mediakentän muutos onkin lähentänyt markkinointi- ja pr-viestintää, ja perinteisesti pr-viestintään lukeutuvia mediaseurannan muuttujia on sisällytetty myös MMM-malleihin (Smith, 2008). Oleellista on määritellä muuttuja, jota vasten muutosta tarkastellaan. Myynnin lisäksi Smith (2008) mainitsee muun muassa maineen, osakearvon, NPS:n (Net Promoter Score ${ }^{1}$ ). Ekonometrisen mallinnuksen ongelmaksi mainitaan sen kompleksisuus - käyttö vaatii erityisosaamista, mallinnus isompaa investointia ja luonnollisesti dataa. (Watson \& Noble, 2007). Ekonometria pyrkii ennustettavuuteen, mikä on kuitenkin ongelmallista toimintaympäristön useiden, toisinaan arvaamattomien muuttujien vuoksi (Smith, 2008).

Keskustelu ROIsta on myös metaforista siinä, miten viestinnän arvo ymmärretään ja miten viestinnän arvoketju muodostuu sekä mitkä tekijät vaikuttavat siihen. Määritelmistä voi lukea, mitä kukin malli pitää tärkeänä ja minkä se olettaa ilmaisevan viestinnän arvon. Excellence-tutkimuksessa osoitettiin, miten viestinnän avulla luodut hyvät suhteet vähentävät kuluja, vähentävät riskiä ja kasvattavat liikevaihtoa. Apuna käytettiin compensating variation -kyselyä, jossa toimitusjohtajia pyydettiin yksinkertaisesti arvioimaan viestinnällä tavoitettu tuotto ja saavutettu arvo. (Grunig,

\footnotetext{
${ }^{1}$ "Kuinka todennäköisesti suosittelisit tätä yritystä ystävälle tai työtoverille?” Vastaukset asteikolla 0-10, jaottelu arvostelijoihin, passiivisiin ja suosittelijoihin. $N P S=($ suosittelijoiden lukumäärä arvostelijoiden lukumäärä)/vastaajien lukumäärä x 10. ks http://www.netpromotersystem.com/systemprocesses/index.aspx
}

2008.) Kyselymallia on esitetty käytettäväksi myös kustannustehokkuusanalyysin yhteydessä (Likely, Rockland \& Wiener, 2006), mutta se ei sisällä konkreettista rahallista arvoa. Excellence-tutkimuksen perusteella Grunig (2008) jopa esittää, ettei viestinnän rahallisen arvon määrittely ROIna ole edes tarpeen.

Kustannustehokkuutta ilmentäviä malleja, kuten kustannustehokkuusanalyysiä (CEA, Cost-Effectiveness Analysis), on tarjottu vaihtoehdoksi ROIlle, mutta ne ovat jääneet vähäiselle huomiolle kirjallisuudessa (Macnamara, 2014). Analyysissä vertaillaan suhteellisia kuluja ja vaikutuksia eri vaihtoehtojen välillä (Likely, 2012). Kustannustehokkuus ymmärretään muodossa euromääräinen kustannus jaettuna tehokkuudella. Kustannus vastaa ROI-kaavan investointia huomioiden kaikki liittyvät kustannukset, tehokkuus taas voidaan määrittää monin eri tavoin tavoitteesta riippuen. Oleellista on käyttää määrällistä mittaria, joka yksinkertaisimmillaan voi viestinnän toimintojen tasolla olla tietyn kohderyhmän peiton vertailu eri medioiden välillä. (emt.) Likelyn (2012) mukaan kustannustehokkuutta voidaan hyödyntää laajasti viestinnän kontekstissa eri viestinnän kanavia tai toimintoja arvioitaessa, mutta myös organisaatiota laajemmin koskevien tuoton lisäämiseen, kulujen leikkaamiseen tai riskien hallintaan tähtäävien ohjelmien tasolla sekä sisäisen palvelun laadun arvioinnissa, mikä tekee siitä hänen mukaansa ROIta monikäyttöisemmän viestinnässä.

Samantyyppiselle laskennalle perustuu kolmannella sektorilla käytetty Social 
Return on Investment (SROI). Sen fokus on tosin pitkäkestoisempi ja laajempi, ja se rakentuu hyötykustannusanalyysin varaan. Analyysissa hyödyt ja kustannukset arvioidaan määrällisesti. SROI viittaa investoinnin tuoton sosiaaliseen ulottuvuuteen, joka on aineetonta ja nivoutuu läheisesti triple bottom line -ajatteluun, jossa taloudellisen tuoton lisäksi tavoitellaan myös muita hyötyjä ja tuloksia (Miller \& Hall, 2013). Se on mittaristo, jonka tarkoituksena on kuvata laajempaa, yhteisöllistä tai yhteiskunnallista tulosta, joka toiminnalla saadaan aikaan. Tällöin mitataan laajempia, hitaasti ilmeneviä vaikutuksia, kuten muutoksia asenneilmapiirissä tai toiminnan tuloksena saavutettua muutosta. SROI mittaa arvoa, ei rahaa, vaikka käyttääkin taloudellisia mittareita tuoton osoittamiseen. PR-sanakirjassa (Stack \& Bowen, 2013) tosin SROIlla tarkoitetaan edellä mainittua sosiaalisen median ROIta, mikä kuvaa hyvin käsitteiden epäselvyyttä.

\section{Kohti strategista tasoa}

Grunig (2006) on korostanut, että viestinnän aineettomat indikaattorit ja niiden arvo tulee osoittaa taloudellisen arvon rinnalla. Vaikuttavuuden tasolla viestinnän tuotto yhdistetään usein siihen aineettomaan pääomaan, joka syntyy viestinnällä ylläpidettyjen suhteiden kautta (Grunig, 2006). Maine on sidosryhmien tulkinta organisaatiosta, ja sen voidaan nähdä ilmentävän suhdetta. Viestinnän vaikutus yrityksen tulokseen on siten välillinen, ei suora.

Kim ja Yang (2013) määrittelevät, että viestinnän panostukset vaikuttavat maineeseen ja maine vaikuttaa kokonaistulokseen. He esittävät käytettäväksi Maine-ROIta (Reputation ROI), jonka pohjana on maineen kokonaisarvo. Tämä kokonaisarvo määritetään hyödyntämällä organisaation omaa aikasarjadataa suhteuttamalla regressioanalyysillä mainemuuttujia liiketaloudellisiin tuloksiin. Pohja on siten ekonometrinen. Kokonaisarviossa voidaan huomioida myös viestinnän säästövaikutus ja muut toimintakentän muutokset hyödyntämällä analyysiä vastaavan kaltaisista kriiseistä tai muutoksista ja huomioimalla niiden taloudellinen vaikutus kokonaisarvoon (Kim \& Yang, 2013). Tämänkaltaisessa arvioinnissa on kuitenkin omat haasteensa.

Varsinainen Maine-ROI rakentuu seuraavalle kaavalle:

Maine-ROI $=\frac{\text { Maineen kokonaisarvo }}{\text { Viestinnän kulut }} \times 100$

Stacksin, Doddin ja Menin (2013) mukaan ROIn taustalla vaikuttavat sidosryhmien odotukset suhteessa organisaatioon eli ROE (Return on Expectation). He määrittelevät maineen muodostuvan uskottavuuden (credibility), luottamuksen (trust) ja suhteiden (relationships) summana, joka muodostaa ROEn. Organisaation on itse tunnistettava siihen kohdistuneet odotukset ja seurattava niiden kehittymistä. On myös huomattava, että sidosryhmien odotukset muuttuvat sen mukaan, miten organisaatio kykenee ne täyttämään. ROE onkin siis paitsi maineen mittari, myös sen indikaattori. Toinen kysymys on, miten 
nämä odotukset tulisi mitata ja ilmaista määrällisesti, jotta ne olisivat integroitavissa ROEna ROIhin.

Nämä mallit ilmentävät aineettomien pääomien määrittelyn ongelmallisuutta. Tiedon tuottaminen kehityksen seuraamiseksi on haasteellista, koska riippuvuussuhteet aineellisten ja aineettomien pääomien välillä eivät ole selkeitä. Taloustieteessä esitetäänkin, että aineettomia pääomia tulisi tarkastella kokonaisuutena, koska ne ovat ennemmin prosessin kuin perinteisen resurssin kaltaisia (Järvenpää, Länsiluoto, Partanen \& Pellinen, 2015). Myös viestinnän ja markkinoinnin alalla on vahvasti esitetty, että tuotto ei ole tavoitettavissa yhdellä mittarilla (Töllinen \& Karjaluoto, 2011; Meng \& Berger, 2012).

Tuloskorttiajattelu (BSC, Balanced Scorecard) on yksi ratkaisumalli, joka sisältää sekä taloudellisia että ei-taloudellisia mittareita (Järvenpää et al., 2015). Ruotsissa esitettiin jo 1990-luvulla käytettäväksi tuloskorttityyppistä tavoitteiden ja avainmittareiden kokonaisuutta nimellä Return on Communication (Sveriges Kommunikatörer, 1996). Malli erittelee 5 segmenttiä, joilla organisaatio voi luoda aineetonta arvoa sidosryhmien kanssa (markkinat/asiakkaat, talous/sijoittajat, työntekijät, yhteisö, johto). Kullekin segmentille määritellään 4-6 suoritusmittaria. Kokonaistuloksellisuuden esittävään malliin pyrkii myös Corporate Communications Scorecard (CCS)(Zerfass, 2008), joka perustuu BSC-malliin lisäten perusnäkökulmiin (taloudellinen, asiakas, prosessi, oppiminen) sosio-poliittisen ulottuvuuden. Tällä viidennellä ulottuvuudella pyritään tavoittamaan yhteiskunnallinen taso viestinnän vaikuttavuuden arvioinnissa. Saksassa esitetty communication controlling -malli yhdistää edelleen avainsuorituskykymittarit (KPI, Key Performance Indicator) tasapainotettuun tuloskorttiin ja pyrkii viestinnän arvoketjun tunnistamiseen yksittäisen mittarin sijaan.

Näkökulmia viestinnän ROIn mittaamiseen on siis useita, mutta mikä on niiden suhde taloustieteen ROIhin? On esitetty, että ROI-käsitteen käyttöä tulisi välttää viestinnän alalla (Watson \& Zerfass, 2012) ja rajoittaa se vain niihin tilanteisiin, joissa sekä tuotto- että kustannuspuoli on määritettävissä rahassa (IPR, 2013). Tämä voi kuitenkin olla vaikeaa jo panosten osalta, sillä viestinnän kulut eivät aina ole määriteltävissä laskentatoimen kustannuslajeittain. Tulosten osalta tarkastelu ei voi rajoittua vain tilikauteen, sillä viestinnän vaikutukset ilmenevät usein viiveellä (Likely, 2012). Likely (emt.) esittää, että todellinen ROI olisi mahdollinen vain organisaatiotasolla. ROIta ei tällöin pyritä muodostamaan yksin viestinnän toiminnoissa vaan siinä, miten arvoketju eri organisaation toimintojen välillä avataan.

Todellisen ROIn määrittäminen edellyttäisi Likelyn (2012) mukaan perus- tai lähtötason määrittelyä vertailukohdaksi, kohdeyleisön seurantaa eri viestinnän tulostasoilla, kaikkien kustannusten huomioimista sekä konversion seuraamista eri organisaation toimintojen osalta. Kustannuksissa huomioitaisiin paitsi kiinteät myös muuttuvat kulut sekä upotettujen kulujen osuus. Tässä konversiolla viitataan tulokseen ainakin kahdella tasolla, ensin viestinnän tuloksena ja sitten muun 
toiminnon tuloksena. Käytännössä viestintäkampanja tuo henkilön ovelle, mutta asiakaspalvelu vie kaupat loppuun. (Likely, 2012.) Näkökulma edustaakin vahvasti integroitua viestintää.

\section{Johtopäätökset}

Pyrkimyksessä esittää viestinnän ROI yhdistyy useampi näkökulma viestinnän mittaamiseen. Kirjallisuudessa esitetyissä ROI-malleissa yhdistyvät taloudelliset, määrälliset ja laadulliset viestinnän mittaamisen näkökulmat ja niissä itse käsitteellä viitataan moniin eritasoisiin viestinnän tuloksiin. Toiveita yhtenäisestä standardista on esitetty mutta myös todettu, ettei ole olemassa yhtä mallia tai yhdellä mittarilla ei voida viestinnän tuottoa tavoittaa (Stacks \& Michaelson, 2011; Watson \& Zerfass, 2011). Tämä siksi, että organisaatioiden strategiset tavoitteet ovat lähtökohtaisesti erilaisia, joten painotukset viestinnän tavoitteissa ovat erilaisia.

Valittaessa tapaa esittää viestinnän ROI olisikin oleellista pohtia, mitä sillä tavoitellaan ja minkälainen malli pystyy vastaamaan tähän tavoitteeseen. Onko tarkoituksena pyrkiä osoittamaan viestintäsijoituksen kokonaistuotto vai kenties vertailla toiminnallisia vaihtoehtoja joko organisaatiotasolla tai viestintätoiminnon tasolla? Tai ehkä tarkoituksena on osoittaa viestinnän lisäinvestointien kasautuva hyöty jossakin muussa organisaation toiminnossa? Mikä on organisaation näkökulmasta viestinnän tärkein tavoite, jota valitun mittarin tulisi kuvata?

Keskustelun ROIsta voi mieltää keskusteluksi viestinnän tuotosta. Juholin (2010) tarjoaa lähtökohdaksi käytännönläheisesti kolme kysymystä, joiden kautta voidaan määrittää ROC (Return on Communication) - mitä aineellista tai aineetonta hyvää viestinnällä tulisi saada aikaan ja vastaavasti mitä negatiivista ehkäistä sekä mikä myönteinen tila tulisi säilyttää. Vastausten perustana tulee luonnollisesti olla organisaation strategia ja sidosryhmien odotukset. Onnistumisen arvioimiseksi valitaan soveltuva mittareiden kokonaisuus.

Viestinnän avulla saavutettavan taloudellisen tuoton pohdinta kannustaa tarkastelemaan viestintää integroidusta näkökulmasta ja tunnistamaan, miten viestintä osallistuu kokonaistuloksen rakentamiseen organisaation eri tasoilla.

\section{Lopuksi: Miten mittaisin?}

Käytännön kannalta oleellista on se, mitä oman organisaation kontekstissa on viestinnällä tarkoitus saavuttaa. Olemme keränneet tämän kirjallisuuskatsauksen pohjalta erilaisia viestinnän tuoton pohdintaan liitettyjä indikaattoreita oheiseen kuvioon, joka on suuntaa-antava eikä suinkaan tyhjentävä (kuvio seuraavalla sivulla). 
Kuva 1. Viestinnän kirjallisuudessa ROI-käsitteeseen ja malleihin liitettyjä tai sisällytettyjä indikaattoreita.
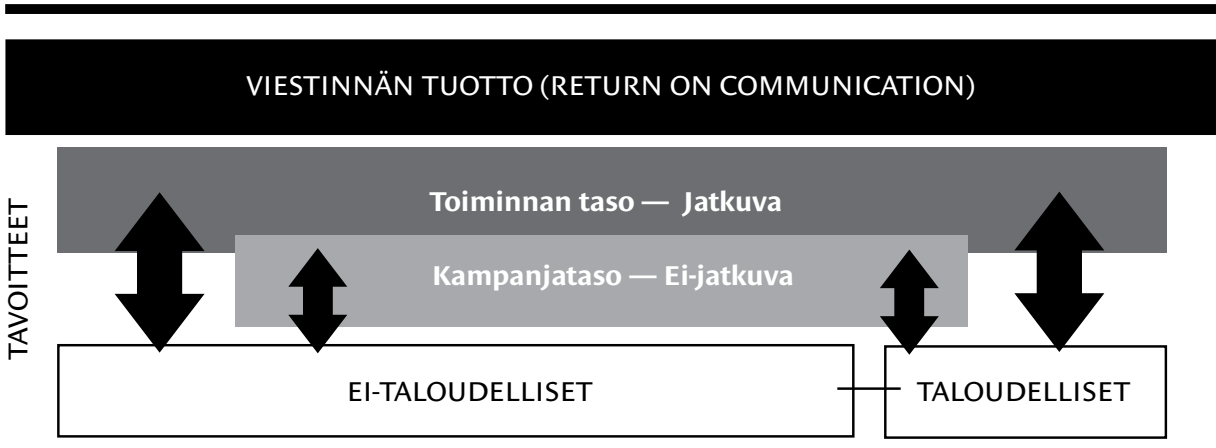

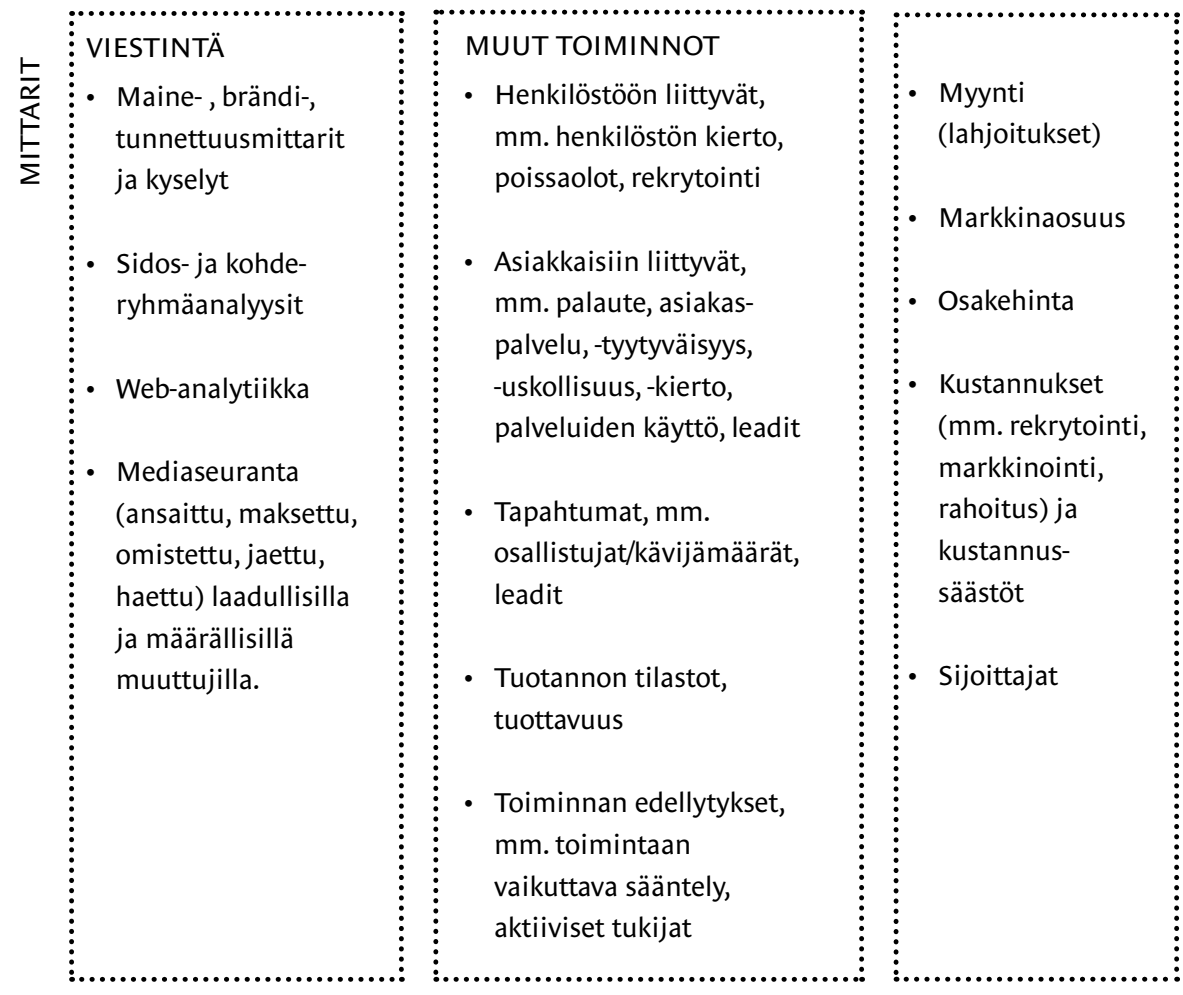


Voit valmistautua keskusteluun viestinnän tuotosta tai ROIsta huomioimalla seuraavia asioita mittaamisessa ja arvioinnissa.

- Selvitä organisaation sisäiset odotukset viestinnän tuoton tai ROIn osoittamisesta.

- Selvitä, mitä olemassa olevaa taloudellista tai asiakkaisiin/kohderyhmiin liittyvää seurantatietoa on hyödynnettävissä.

- Seuraa valitsemiasi indikaattoreita systemaattisesti suhteessa viestinnän panostukseen ja mittareihin.

- Huomioi markkinoinnin panostukset ja tee yhteistyötä.

- Rajaa tarkastelun konteksti kampanja vai jatkuva?

- Arvioi, mitkä asiat ovat ylipäätään mitattavia ja millä aikavälillä.

- Huomioi toimintaympäristössä ja arvomaailmassa tapahtuvat muutokset.

\section{Näistä voit aloittaa:}

Juholin, E (2010). Arvoi ja paranna! Viestinnän mittaamisen opas. Helsinki: Infor

-Suomenkielinen perusteos viestinnän mittaamiseen.

Guidelines and Standards for Measuring the Effectiveness of PR Programs and Activities: http://www.instituteforpr.org/ wp-content/uploads/2002_MeasuringPrograms.pdf

-Opas viestintätoimintojen, -strategioiden ja -kampanjoiden tulosten ja tehokkuuden mittaamiseen ja arviointiin.

AMEC Integrated Evaluation Framework: http://amecorg.com/amecframework/ -Kattava kuvaus viestinnän arvioinnin kokonaisuudesta. ROIn sijoitus mittaamisen viitekehyksessä.

Dictionary of Public Relations Measurement and Research: http://www. instituteforpr.org/dictionary-public-relations-measurement-research-third-edition/ -Sanastoa viestinnän mittaamiseen liittyen useissa eri kieliversioissa.

Communication Controlling (Deutsche Public Relations Gesellschaft e.V.): http://www.communicationcontrolling.de/ -Portaali viestinnän arvonmuodostuksesta ja arvioinnista.

\section{LÄHTEET:}

AMEC (2016). A Taxonomy of Evaluation Towards Standards. Saatavilla verkossa: http://amecorg. com/amecframework/home/supporting-material/taxonomy/. Luettu 23.9.2016.

AMEC (2011). Valid Metrics for PR Measurement - Putting the Principles Into Action. Saatavilla verkossa: http://apps.prsa.org/Intelligence/ BusinessCase/Documents/AMEC/20110607Va- 
lidMetricsforPRMeasurement.pdf. Luettu 16.3.2016.

Delahaye Paine, K. (2011). Measure What Matters - Online Tools for Understanding Customers, Social Media, Engagement and Key Relationships. Hoboken: John Wiley \& Sons.

\section{ECM (2015). European Communication Mo-} nitor. 2015 Chart Report. Saatavilla verkossa: http://www.zerfass.de/ECM-WEBSITE/media/ ECM2015-Results- ChartVersion.pdf. Luettu 6.11.2015.

Grunig, J. (2006). Furnishing the edifice: Ongoing research on public relations as a strategic management function. Journal of Public Relations Research, 18, 151-176.

Grunig, J. (2008). Conceptualizing Quantitative Research in Public Relations. Teoksessa van Ruler, B., Vercic, A. \& Vercic, D. (toim.) Public Relation Metrics Research and Evaluation. New York: Routledge, 88-119.

IPR (2013). Retun on Investment (ROI). Institute of Public Relations. Versio 1.0, päivitetty David Geddes 2.11.2012. Saatavilla verkossa: http:// www.instituteforpr.org/return-on-investment-roi/

IPR (2015). Barcelona Principles 2.0 - Updated 2015. Institute for Public Relations.

Saatavilla verkossa: http://www.instituteforpr. org/barcelona-principles-2-0-updated-2015/. Luettu 5.11.2015.

Juholin, E. (2010). Arvioi ja paranna! Viestinnän mittaamisen opas. Helsinki: Infor. Järvenpää, M., Länsiluoto, A., Partanen, V. \&
Pellinen, J. (2015). Talousohjaus ja kustannuslaskenta. Helsinki: Sanoma Pro. 2.-3. painos.

Kim, Y. \& Yang, J. (2013). Corporate Reputation and Return on Investment (ROI): Measuring the Bottom-line Impact of Reputation. Teoksessa Carroll, C. E. (toim.) Handbook of Communication and Corporate Reputation. Chicester: Wiley-Blackwell, 574-589.

Likely,F., Rockland, D. \& Weiner, M. (2006). Perspectives on the ROI of Media Relations Publicity Efforts. Institute of Public Relations. Saatavilla verkossa: http://www.instituteforpr. org/wp-content/uploads/2006_ROI_LRW.pdf. Luettu 30.10.2015.

Likely, F. (2012). Principles for the Use of Return on Investment (ROI), Benefit-Cost Ratio (BCR) and Cost-Effectiveness Analysis (CEA) Financial Metrics in a Public Relations/Communication Department. Esitelmä, 15th International Public Relations Research Conference, 337-358. Saatavilla verkossa: http://www.instituteforpr.org/ wp-content/uploads/15th-IPRRC-Proceedings1. pdf. Luettu 1.12.2016.

Macnamara, J. (2014). Emerging international standards for measurement and evaluation of public relations: A critical analysis. Public Relations Inquiry, 3(1), 7-29.

Macnamara, J. (2015). Breaking the measurement and evaluation deadlock: a new approach and model.Journal of Communication Management, 19(4), 371-387.

Meng, J. \& Berger, B. K. (2012). Measuring 


\section{O, / 135}

return on investment (ROI) of organizations' internal communication efforts. Journal of Communication Management, 16(4), 332-354.

Millar, R \& Hall, K. (2013). Social Return on Investment (SROI) and Performance Measurement. Public Management Review, 15(6), 923-941.

Nicholls, J. (2007). Why Measuring and Communicating Social Value can help Social Enterprise become More Competitive. London: Cabinet Office.

Smith, B. (2008). Representing PR in the Marketing Mix - A Study on Public Relations Variables in Marketing Mix Modeling. Institute for Public Relations. Saatavilla verkossa: http://www. instituteforpr.org/pr-marketing-mix/. Luettu 1.11.2016.

Stacks, D. (2015). What's the Relationship between Social Media ROE and Business ROI? Institute for Public Relations. Saatavilla verkossa: http://www.instituteforpr.org/whats-relationship-social-media-roe-business-roi/. Luettu 19.2.2017.

Stacks, D. \& Bowen, S. (2013). Dictionary of Public Relations Measurement and Research. Institute for Public Relations. 3. painos. Saa-

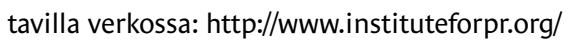
wp-content/uploads/Dictionary-of-Public-Relations-Measurement-and-Research-3rd-Edition. pdf. Luettu 16.11.2015.

Stacks, D., Dodd, M. \& Meng, L. (2013). Corporate Reputation Measurement and Evaluation.
Teoksessa Carroll, C. E. (toim.) Handbook of Communication and Corporate Reputation. Chicester: Wiley-Blackwell.

STT Viestintäpalvelut Oy \& ProCom - Viestinnän ammattilaiset ry (2016). Viestinnän mittaamisen tila suomalaisissa organisaatioissa. Saatavilla verkossa: http://procom.fi/wp-content/ uploads/2016/02/Viestinn\%C3\%A4n-mittaaminen_tutkimusraportti.pdf. Luettu 2.2.2016.

Sveriges Kommunikatörer (1996). Return on Communications. Saatavilla verkossa: https:// sverigeskommunikatorer.se/globalassets/dokument/forskningsrapporter/returnoncommunication.pdf. Luettu 7.9.2016.

Töllinen A. \& Karjaluoto H. (2011). Marketing communication metrics for social media. International Journal of Technology Marketing, 6(4), 316-330.

Watson, T. (2011). An initial investigation on the use of 'Return on Investment' in public relations practise. Public Relations Review, 37, 314-317.

Watson T. \& Noble P. (2007). Evaluating Public Relations - A Best Practice guide to Public Relations Planning, Research and Evaluation. London: Kogan Press. 2. painos.

Watson, T. \& Zerfass, A. (2011). Return on investment in public relations: A critique of concepts used by practitioners from communication and management sciences perspectives. PRism, 8(1). Saatavilla verkossa: http://www.prismjournal.org/homepage.html. Luettu 2.11.2015. 
Zerfass, A. (2008). The Corporate Communications Scorecard A framework for Managing and Evaluating Communication Strategies. Teoksessa van Ruler, B., Vercic, A. \& Vercic, D. (toim.) Public Relation Metrics Research and Evaluation. New York: Routledge, 88-119. 
o, 


ProComma Academic edistää viestintäalan keskustelukulttuuria yhteiskunnassa. Julkaisu on viestinnän ammattilaisten yhdistyksen ProCom ry:n kustantama, ja se pohjaa 1950-luvulla aloitettuun perinteeseen levittää ajankohtaista viestintäalan tietoa. Academic-liite tarkoittaa sitä, että tieto perustuu tutkimuksiin.

ProComma kerää yhteen tutkimuksia ja teoriaa organisaatioiden jatkuvasti muuttuvasta toimintaympäristöstä. Kirjoittajiksi kutsutaan asiantuntijoita eri yliopistoista, mutta myös akateemisen maailman ulkopuolelta.

Vuosittain ilmestyvällä ProCommalla on teema. Tässä numerossa pureudutaan mitattavaan viestintään. 